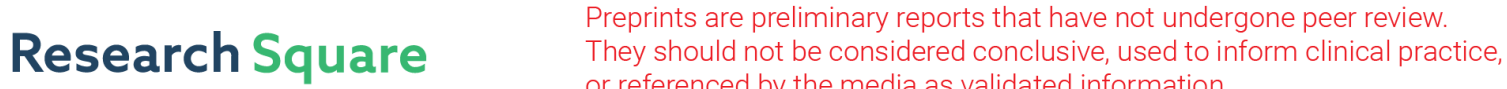 or referenced by the media as validated information. \\ The Study of Iranian Teachers' and Learners' Perceptions Towards Implicit and Explicit form - Focused Instruction of Speech Acts
}

\section{Melahat Amir Jahansouz Shahi}

Islamic Azad university, Varamin, Pishva branch

Neda Gharagozloo ( $\sim$ N.gh@iauvaramin.ac.ir)

Islamic Azad university, Varamin, Pishva branch https://orcid.org/0000-0002-4443-4033

\section{Original article}

Keywords: Pragmatic competence, speech act, form-focused instruction, implicit and explicit knowledge

Posted Date: September 10th, 2020

DOI: https://doi.org/10.21203/rs.3.rs-72116/v1

License: (c) (i) This work is licensed under a Creative Commons Attribution 4.0 International License.

Read Full License 


\section{Abstract}

Pragmatic competence is an essential component in communicative competence (Bachman \& Palmer, 2010; Canale, 1983). Therefore, teaching pragmatic knowledge plays an important role in a foreign language curriculum, particularly in teaching English as a Foreign

Language (EFL). However, there exists a lack of literature about the teaching of pragmatics with little empirical research on teachers' and learners' perceptions in Iran.

The purpose of this study is to investigate the impact of focus-on-form instruction (FFI) speech acts on Iranian EFL learners' pragmatic competence. Cooperative grouping, role plays, and other pragmatically oriented tasks were used to promote the learning of the intended speech acts. To come up with conclusive and persuasive findings, 132 Iranian male and female learners, intermediate-above, served as the subjects. The Oxford Placement Test (OPT) was used to evaluate the participants' language proficiency level. Teachers' and students' questionnaires about the instructions and teachers' interview were used as the instruments in this study. Data collected by different instruments were analyzed and compared by way of a mixed method and. then was triangulated to enhance its validity and reliability. The finding of the study showed that explicitness leads to better pragmatic knowledge development than the implicit knowledge. This study showed that consciousness-raising at the metapragmatic level improved EFL learners' pragmatic performance and variety of form-strategy use substantially; thus, it should be taken more seriously in L2 instruction and material development.

\section{Introduction}

Effective communication requires more than just knowing the linguistic knowledge of the language such as phonology, morphology, and syntax. It means that in order to make learners become communicatively competent in English language, there should be a shift from previous theoretical frameworks, which considered language as a formal system based on grammatical rules, toward a more communicative perspective (Martínez-Flor, 2004).

Teaching pragmatics as well as its components resulting in pragmatic learning development has been highlighted in educational contexts. One of these factors is the role of instruction on learners' awareness and production of speech acts which has generated a lot of interests in the field of ILP (Alcón \& Pitarch, 2010). According to Schmidt 's (1993) noticing hypothesis, the rationale for the need of instruction in pragmatics is that simple exposure to the target language is not enough for developing pragmatic competence. He believed that pragmatic functions and relevant contextual factors are often not salient to learners and thus not likely to be noticed even after prolonged exposure.

By the same token, Willis and Willis (1996) stated that through instruction, learners are provided with guidelines and, more importantly, with activities encouraging them to think about samples of language and to draw their conclusions about how the language works (p. 2). While working on the impact of C-R and teaching methodology factors, Sedighi and Nazari (2007, p. 22) noted that language awareness 
approaches do not cause language acquisition to take place but those approaches which focus on learner investment and learner discovery do help learners to pay more attention to features of their input and can create the curiosity, alertness and positive valuation which are regarded as prerequisites for the development of communicative competence.

Recent studies in the area of L2 pragmatic development has focused on input, individual differences, and noticing (e.g., Kasper \& Rose, 2002; Takahashi, 2005a) as well as pragmatic transfer from a learner's first language (Al-Issa, 2003; Byon, 2004; Rose, 2000; Yoon, 1991) and classroom instructional practices (e.g., Davies, 2004; Rose, 2005; Rose \& Kasper, 2001; Yates, 2004) as they affect the acquisition of pragmatic competence in L2. Also, the type of data best suited for pragmatics studies is another aspect of developmental pragmatics research that has received much attention recently. Bardovi-Harlig and Hartford $(2005)$ as well as Ohta $(2001,2005)$ have pointed out the desirability of conducting research in interlanguage pragmatics and developing L2 pragmatics research that relies almost exclusively on naturally occurring classroom data and naturalistic observational research.

\section{Approaches to teaching pragmatics (Explicit vs. Implicit instruction)}

According to previous studies (Bardovi-Harlig, 2001; Kasper, 2001; Halenko \& Jones, 2011; Olshtain \& Cohen, 1990), it seems that those learners who receive instruction in pragmatics perform and act better than those who do not. Assisted performance, in both explicit and implicit instructions in the EFL context, provides learners with desirable amount of input and opportunities to practice. With explicit instruction, the teacher provides suggestions and explanations to the class while implicit instruction makes no overt reference to the rules (Alcón Soler, 2002; Schmidt, 1993). An explicit approach means that the brain solves the problems consciously en attempting to search related memory. Students learn well when they are required to learn from logical relationships rather than perceptual similarity (Schmidt, 1990).

Normally, explicit instruction includes describing, explaining, and discussing a target form, and making 12 comparisons between L1 and L2 data (Salemi, Rabiee \& Ketabi, 2012). Numerous researchers have investigated the effect of explicit and implicit instruction. On the other hand, Dole (2000) defined implicit instruction by explaining teacher's role in an implicit instruction classroom. Dole's (2000) study found that implicit instruction places the teacher in the role of facilitator, rather than guide or expert. The teacher's role is to provide the rich context, which includes lots of books to read, time to read and write, and real purposes for reading and writing. (p. 59) Implicit teaching also refers to "the practice of deliberately leaving it to learners to discover or work out these things for themselves" (Cambourne, 1999, p. 126). On the whole, implicit instruction has drawn less attention than explicit instruction in the language instruction and has a more vague definition. However, it is worth mentioning that implicit instruction is different from simply exposure to input. One example of implicit instruction is found in Tateyama's (2001) study in which the explicit group received handouts and videos to illustrate and explain the different strategies to be used in different social context,whereas the implicit group watched the same clip twice. The other difference between her explicit and implicit treatments was that the students in the implicit group were prompted to pay attention to any formulaic pragmatic routines to avoid distraction by other interesting aspects of the video before watching the video (Tateyama, 2001, p. 204). Hence, implicit 
instruction also has instruction involved, but from using a less direct and more student-centered approach. Considering the literature, the present study investigated the effects of specific instructional approaches on developing L2 pragmatic competence and the teachers' and learners' perception towards the explicit and implicit presentation of speech acts.

\section{PURPOSE OF THE STUDY}

The majority of studies on the use of pragmatics have been conducted in settings where English is a second language (ESL) or in settings such as India, Malaysia, and Singapore, where there is abundant interaction between the locals and English speaking expatriates and hence the context of language learning very much approaches ESL situations. In other words, pragmatics mainly addresses ESL settings where learners' primary objective is having real-life interactions both inside and more importantly outside the classroom. ESL settings also privilege learners with native or near-native teachers together with high amount of exposure in the form of intensive courses. In Iran, however, the chance of using English outside the classroom is very limited and perhaps far less than many other EFL settings. The immediate objective of a great majority of English learners in Iran is not communication in real life situations but success in some kind of exam. Children and adolescents are headed for the centralized university entrance exam and many adults need to sit for some high-stakes tests such as IELTS or TOEFL for educational or immigration purposes.

Due to the consensus over the need to teach pragmatic competence, the main issue now centers on the question of how we should teach this competence in the most effective way. Therefore, the present study is to address the impact of focus-on-form instruction (FFI) on implicit and explicit of speech acts on Iranian EFL learners' pragmatic competence, aims to investigate the relative effectiveness of consciousness-raising (C-R) on the development of the speech act.

\section{Research questions}

1- What are learners' perceptions regarding explicit versus implicit speech acts?

2- What are teachers' perceptions regarding explicit versus implicit speech acts?

3- What are the teachers' views, and experiences about their teaching English through Form Focused Instruction (FFI) in EFL classes?

\section{Literature Review}

Efforts to understand the acquisition of pragmatics have not provided a coherent picture of the process, and calls for more systematic investigations that encompass more of the complexity of the acquisition of L2 pragmatic competence have persisted from the early years of inter language pragmatic research (e.g., Thomas, 1983) to more recent efforts (e.g., Hassall, 2004). In order to understand developing L2 pragmatics more fully, it is helpful to situate the process within the larger second language acquisition (SLA) process (Kasper \& Schmidt, 1996). Here, the goal of locating developing L2 pragmatic competence 
within SLA is addressed through an examination of the connections between SLA and communicative competence, SLA and pragmatic competence, and instruction and developing L2 pragmatic competence.

One important learning resource is classroom management, because in this activity language does not function as an object for analysis and practice but as a means for communication. From the studies reviewed earlier and from other theory and research of SL learning, we can distill a number of activities that are useful for pragmatic development. Such activities can be classified into two main types: activities aiming at raising students' pragmatic awareness, and activities offering opportunities for communicative practice.

Through awareness-raising activities, students acquire socio pragmatic and pragma linguistic information - for instance, what function complimenting has in mainstream American culture, what appropriate topics for complimenting are, and by what linguistic formulae compliments are given and received. Students can observe particular pragmatic features in various sources of oral or written 'data', ranging from native speaker 'classroom guests' (Bardovi-Harlig, et al., 1991) to videos of authentic interaction, feature films (Rose, 1997), and other fictional and non-fictional written and audiovisual sources.

Much research over the past several years has focused on the effects of various aspects of L2 instruction on learners' developing pragmatic competence (e.g., Liddicoat\& Crozet, 2001; Rose \& Ng, 2001; Tateyama, 2001).

Studies such as Kanagy's (1999) and Lyster's (1994) shed light on the general effects of formal instruction (immersion in particular) on child L2 pragmatic competence development, and have the added benefit of being analogous in terms of participants and the context of instruction to Swain (e.g., 1998) and Swain and Lapkin's (e.g., 1995) research into the role of output in the SLA processes of French immersion students.

Recently some research studies have been concerned with emphasizing the importance of coming up with unified and comprehensive rating criteria in pragmatic assessment in Iran. For example, Alemi (2012) investigated the criteria that native English teachers and non-native Iranian English teachers consider when rating EFL learners' pragmatic productions regarding the speech act of apology and refusal. Besides discovering the criteria of the raters, Tajedin and Alemi (2013) emphasized the existence of any bias among the raters.

Abolfathiasl and Abdullah (2015) examined the impact of pragmatic consciousness-raising activities on EFL learners' immediate and delayed performance of suggestions. Shokouhi \& Amir Rezaei (2015) explored the importance of teaching pragmatics in the classrooms. Zangoei, Nourmohammadi and Derakhshan (2014) investigated the relative effectiveness of consciousness-raising listening prompts on the development of the speech act of apology. Birjandi and Derakhshan (2014) investigated the relative effectiveness of C-R video-driven prompts on the comprehension of three speech acts on Persian learners of English. 
Rahimi Domakani, Hashemian and Mansoori (2014) investigated the effect of bilingualism on pragmatic awareness and development among Iranian Turkish/Persian EFL learners. Bagheri and Hamrang (2013) worked on the effect of meta-pragmatic instructions on the interpretation and use of apology speech acts of English on Iranian intermediate EFL learners.

\section{Methodology \\ 3.1. Design}

The present study made use of sequential explanatory mixed method design and triangulated data to enhance the credibility and validity of the study. In the sequential explanatory design, priority, typically, is given to the quantitative approach because the quantitative data collection comes first in the sequence and often represents the major aspect of the mixed-methods data collection process. The smaller qualitative component follows in the second phase of the research.

\subsection{Participants}

To come up with conclusive and persuasive findings, 130 Iranian male and female students between 17 and 30 years of age were served as the subjects. They major in English language teaching and translation courses at the Islamic Azad University North Tehran, high school students, and those who study English in institution. All the participants were non-native and their language proficiency levels were suggested to be intermediate above. They were divided into two groups. Each group contained 66 participants who received different treatments.

\subsection{Materials and Instrumentation}

The instruments used to gather data in the current study are as follows:

1- Oxford Placement Test (OPT) was used for the selection of homogeneous participants with regard to their level of language proficiency.

2- The teachers' and students' questionnaires were used to evaluate perceptions regarding explicit versus implicit speech acts.

3- Teachers' interview, semi-structured interview, was administered to examine teachers' perceptions of pragmatics and their classroom teaching.

\subsection{Procedure}

The scope of this study was limited to the request, apology, and invitation speech acts. The rationales behind this selection was, firstly, the fact that these speech acts are observed most frequently in daily communications of any speaker. Secondly, these speech acts are the most empirically-explored speech acts in the cross-cultural or inter-language pragmatics literature. 
The participants were homogenized in terms of their level of English proficiency, Oxford Placement Test (OPT) was administered. So, 132 male and female intermediate-above learners took part in the virtual course of study.

Two intact groups were used to compare the effectiveness of C-R activities. One group (explicit group) was provided with a focus on forms instruction based on the use of explicit awareness-raising tasks on requests, apologies, invitations and provision of metapragmatic feedback. Another group (implicit group) received a focus on form instruction utilizing input enhancement on pragmalinguistic and sociopragmatic factors involved in requesting, apologizing, invitations and made use of implicit awareness-raising tasks. Both groups were exposed to excerpts taken from the textbook Top Notch 1B (Saslow and Ascher, 2007) and another textbook Tactics for Listening (Richards, 2003) with the focus on requests, apologies, and invitations in 16 sessions, meeting a 90-minute session a week for the treatment. Also the book "Communicating in English, 1" (Matreyek, 1990) was applied as treatment for the explicit group to provide some metapragmatic explanation.

The piloting of the items in the questionnaire was believed to test the validity and reliability of the items. The students' questionnaire adopted by Hyekyeng Kim Hankuk University of Foreign Studies, Seoul, Republic of Korea, and adapted by the researcher. It consisted of 23 questions which asked the degree of interest, motivation, helpfulness, importance, and difficulty of learning the speech acts for each of the three speech acts on a four-point Likert scale with different semantic differential (e.g. Very interested; Fairly interested; Not much interested;. Not interested).

The teachers' questionnaire was used to evaluate perceptions concerning explicit versus implicit speech acts. The teachers' questionnaire adopted by the researcher and validity of the test was calculated by the panel of expert.

Also, it should be mentioned that before conducting the data collection, ethical considerations were adopted by the researcher. As well, learners were informed about the objectives of the present study and they were guaranteed that the results would be kept confidential and no other use would be done by their responses.

Apart from administering the questionnaire, the interview was relied upon for in-depth data collection. Interviewing is a most often used and powerful strategy for data collection to gain participants' insights into social phenomena (Dornyei, 2007; Fontana \& Frey, 2003).

Teachers' interview was used as a last instrument in the study, adopted by the researcher and was piloted by five teachers, some items were either reworded or omitted based on the teachers' comments. Semistructured interview was administered to examine teachers' perceptions of pragmatics and their classroom teaching. The semi-structured interview consisted of 10 questions covering the importance of teaching pragmatic and the strategies used in the constructs. Each interview session lasted between 15 and 20 minutes. All the procedure was audio-recorded for the data analysis. 


\section{Data Analysis}

\subsection{Quanitative Data Analysis}

\section{Exploring First Research Question}

What are learners' perceptions regarding explicit versus implicit speech acts?

The learners' questionnaire included 23 which can be classified into five categories, each including four items as follows;

- Items 1 to 4 : Interest in learning speech acts,

- Items 5 to 8: Usefulness of speech acts,

- Items 9 to 12: State of being motivating,

- Items 13 to 16: Difficulty of learning speech acts and

- Items 17 to 20 : Importance of learning speech acts.

The last three questions target: a) importance of skills to learn, b) necessity of learning speech acts, and c) how movies facilitated learning speech acts. Thus the main results will be discussed under six subsections.

\subsubsection{Interest in Explicit Learning of Speech Acts}

Table 1 displays the frequencies, percentages and descriptive statistics for the first four items related to "interest in learning speech acts" being taught using an explicit method. Based on these results it can be concluded that EFL learners believed that they were most interested in explicit learning of speech act of request (Mean $=3.92$ ). This was followed by explicit learning of invitations (Mean $=3.88$ ), apologies $($ Mean $=3.85)$ and learning pragmatic features of specific speech acts $($ Mean $=3.71)$. 
Table 1

Descriptive Statistics: Interest in Explicit Learning of Speech Acts

\begin{tabular}{|c|c|c|c|c|c|c|c|}
\hline & \multirow[b]{2}{*}{$\mathrm{N}$} & \multicolumn{2}{|c|}{$\begin{array}{l}\text { Fairly } \\
\text { Interested }\end{array}$} & \multicolumn{2}{|c|}{$\begin{array}{l}\text { Very } \\
\text { Interested }\end{array}$} & \multirow[b]{2}{*}{ Mean } & \multirow[b]{2}{*}{$\begin{array}{l}\text { Std. } \\
\text { Deviation }\end{array}$} \\
\hline & & Freq. & $\%$ & Freq. & $\%$ & & \\
\hline $\begin{array}{l}\text { How interested are you in learning the } \\
\text { pragmatic features of the specific speech } \\
\text { acts? }\end{array}$ & 66 & 19 & 28.8 & 47 & 71.2 & 3.71 & .456 \\
\hline $\begin{array}{l}\text { How interested are you in learning the } \\
\text { pragmatic features of the speech act of } \\
\text { apologies in a target language? }\end{array}$ & 66 & 10 & 15.2 & 56 & 84.8 & 3.85 & .361 \\
\hline $\begin{array}{l}\text { How interested are you in learning the } \\
\text { pragmatic features of the speech act of } \\
\text { invitations in a target language? }\end{array}$ & 66 & 8 & 12.1 & 58 & 87.9 & 3.88 & .329 \\
\hline $\begin{array}{l}\text { How interested are you in learning the } \\
\text { pragmatic features of the speech act of } \\
\text { requests in a target language? }\end{array}$ & 66 & 5 & 7.6 & 61 & 92.4 & 3.92 & .267 \\
\hline
\end{tabular}

The frequencies and percentages further supported the descriptive statistics discussed above. The results indicated that 92.4 percent of EFL learners believed that they were very interested in explicit learning of speech act of request. This was followed by $87.9 \%$ who were interested in learning speech act of invitation, $84.8 \%$ for learning apology and 71.2 percent for learning pragmatic features of specific speech acts.

\subsubsection{Interest in Implicit Learning of Speech Acts}

Table 2 displays the frequencies, percentages and descriptive statistics for the first four items related to "interest in learning speech acts" being taught using an implicit method. Based on these results it can be concluded that, unlike the explicit method, EFL learners believed that they were most interested in implicit learning of speech act of invitation (Mean $=3.92$ ). This was followed by implicit learning of requests $($ Mean $=3.86)$, apologies $($ Mean $=3.74)$ and learning pragmatic features of specific speech acts $($ Mean $=$ $3.67)$. 
Table 2

Descriptive Statistics: Interest in Implicit Learning of Speech Acts

\begin{tabular}{|c|c|c|c|c|c|c|c|}
\hline & \multirow[b]{2}{*}{$\mathrm{N}$} & \multicolumn{2}{|c|}{$\begin{array}{l}\text { Fairly } \\
\text { Interested }\end{array}$} & \multicolumn{2}{|c|}{$\begin{array}{l}\text { Very } \\
\text { Interested }\end{array}$} & \multirow[b]{2}{*}{ Mean } & \multirow[b]{2}{*}{$\begin{array}{l}\text { Std. } \\
\text { Deviation }\end{array}$} \\
\hline & & Freq. & $\%$ & Freq. & $\%$ & & \\
\hline $\begin{array}{l}\text { How interested are you in learning the } \\
\text { pragmatic features of the specific speech } \\
\text { acts? }\end{array}$ & 66 & 22 & 33.3 & 44 & 66.7 & 3.67 & .475 \\
\hline $\begin{array}{l}\text { How interested are you in learning the } \\
\text { pragmatic features of the speech act of } \\
\text { apologies in a target language? }\end{array}$ & 66 & 17 & 25.8 & 49 & 74.2 & 3.74 & .441 \\
\hline $\begin{array}{l}\text { How interested are you in learning the } \\
\text { pragmatic features of the speech act of } \\
\text { requests in a target language? }\end{array}$ & 66 & 9 & 13.6 & 57 & 86.4 & 3.86 & .346 \\
\hline $\begin{array}{l}\text { How interested are you in learning the } \\
\text { pragmatic features of the speech act of } \\
\text { invitations in a target language? }\end{array}$ & 66 & 5 & 7.6 & 61 & 92.4 & 3.92 & .267 \\
\hline
\end{tabular}

The frequencies and percentages further supported the descriptive statistics discussed above. The results indicated that 92.4 percent of EFL learners believed that they were very interested in implicit learning of speech act of invitation. This was followed by $86.4 \%$ for implicit learning of speech act of requests, $74.2 \%$ for learning apologies and 66.7 percent for learning pragmatic features of specific speech acts.

\subsubsection{Comparing Interest in Explicit vs. Implicit Learning of Pragmatic Features of Speech Acts}

Table 3 compares the EFL learners' perceptions towards the explicit vs. implicit learning of pragmatic features of speech acts. The results indicated that the EFL learners were more interested in explicit learning of pragmatic features of speech acts (Mean $=3.71 \mathrm{vs}$. Mean $=3.67)$. They also believed that they were more interested in learning of pragmatic features of speech acts explicitly (Very Interested = $71.2 \%$ vs. $66.7 \%)$. Although the descriptive results supported EFL learners' preference over explicit learning of pragmatic features of speech acts; the results of independent-samples t-test $(t=.561, p=$ $.576)$ indicated that the difference between two means were not statistically significant. 
Table 3

Descriptive Statistics; Interest in Learning Pragmatic Features of Speech Acts by Groups

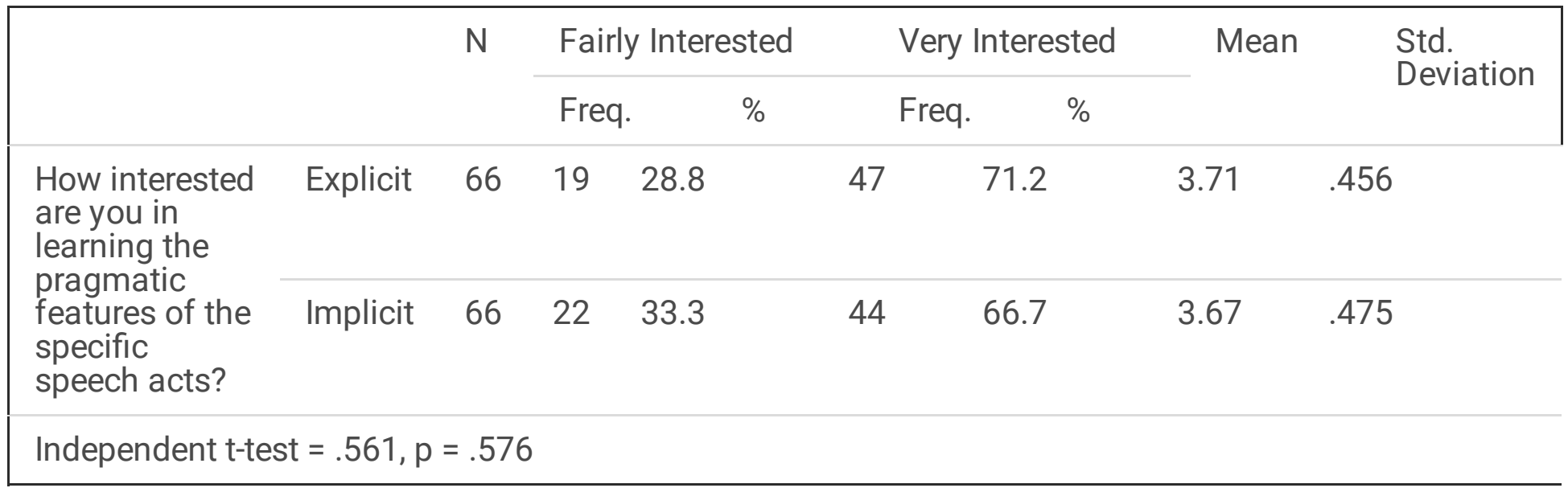

\subsubsection{Comparing Interest in Explicit vs. Implicit Learning of Pragmatic Features of Speech Acts of Invitations}

Table 4 compares the EFL learners' perceptions towards the explicit vs. implicit learning of pragmatic features of speech acts of invitations. The results indicated that the EFL learners were more interested in learning the pragmatic features of the speech acts of invitations implicitly (Mean $=3.92 \mathrm{vs}$. Mean $=3.88$ ). The frequencies and percentages also supported the preference of implicit method over the explicit one. The EFL learners claimed that they were more interested in implicit learning of pragmatic features of speech acts of invitations (Very Interested $=92.4 \%$ vs. $87.9 \%$ ). Despite preference implicit learning of invitation; the results of independent-samples t-test $(t=.872, p=.385)$ indicated that the difference between two means were not statistically significant.

Table 4

Descriptive Statistics; Interest in Learning Pragmatic Features of Speech Acts of Invitations by Groups

\begin{tabular}{|c|c|c|c|c|c|c|c|c|}
\hline & & \multirow[t]{2}{*}{$\mathrm{N}$} & \multicolumn{2}{|c|}{$\begin{array}{l}\text { Fairly } \\
\text { Interested }\end{array}$} & \multicolumn{2}{|c|}{$\begin{array}{l}\text { Very } \\
\text { Interested }\end{array}$} & Mean & \multirow[t]{2}{*}{ Std. Deviation } \\
\hline & & & Freq. & $\%$ & Freq. & $\%$ & & \\
\hline \multirow{2}{*}{$\begin{array}{l}\text { How interested are } \\
\text { you in learning the } \\
\text { pragmatic } \\
\text { features of the } \\
\text { speech act of } \\
\text { invitations in a } \\
\text { target language? }\end{array}$} & Explicit & 66 & 8 & 12.1 & 58 & 87.9 & 3.88 & .329 \\
\hline & Implicit & 66 & 5 & 7.6 & 91 & 92.4 & 3.92 & .267 \\
\hline Independent t-test = & $872, p=.3$ & & & & & & & \\
\hline
\end{tabular}




\subsubsection{Comparing Interest in Explicit vs. Implicit Learning of Pragmatic Features of Speech Acts of Apologies}

Table 5 compares the EFL learners' perceptions towards the explicit vs. implicit learning of pragmatic features of speech acts of apologies. Based on the results displayed in Table 4.15 it can be concluded that the EFL learners preferred more to learn speech acts of apologies explicitly (Very Interested $=84.8 \%$, Mean $=3.85$ ) than implicitly (Very Interested $=74.2 \%$, Mean $=3.74$ ). The results of independent-samples $\mathrm{t}$-test; however, indicated that the difference between two means were not statistically significant $(\mathrm{t}=$ $1.512, \mathrm{p}=.133)$.

Table 5

Descriptive Statistics; Interest in Learning Pragmatic Features of Speech Acts of Apologies by Groups

\begin{tabular}{|c|c|c|c|c|c|c|c|c|}
\hline & & \multirow[t]{2}{*}{$\mathrm{N}$} & \multicolumn{2}{|c|}{$\begin{array}{l}\text { Fairly } \\
\text { Interested }\end{array}$} & \multicolumn{2}{|c|}{$\begin{array}{l}\text { Very } \\
\text { Interested }\end{array}$} & \multirow[t]{2}{*}{ Mean } & \multirow[t]{2}{*}{$\begin{array}{l}\text { Std. } \\
\text { Deviation }\end{array}$} \\
\hline & & & Freq. & $\%$ & Freq. & $\%$ & & \\
\hline \multirow{2}{*}{$\begin{array}{l}\text { How interested are you in } \\
\text { learning the pragmatic } \\
\text { features of the speech act } \\
\text { of apologies in a target } \\
\text { language? }\end{array}$} & Explicit & 66 & 10 & 15.2 & 56 & 84.8 & 3.85 & .361 \\
\hline & Implicit & 66 & 17 & 25.8 & 49 & 74.2 & 3.74 & .441 \\
\hline
\end{tabular}

\subsubsection{Comparing Interest in Explicit vs. Implicit Learning of Pragmatic Features of Speech Acts of Request}

Table 6 compares the EFL learners' perceptions towards the explicit vs. implicit learning of pragmatic features of speech acts of request. The results indicated that the EFL learners were more interested in learning the pragmatic features of the speech acts of request explicitly (Mean $=3.92 \mathrm{vs}$. Mean $=3.86$ ). The frequencies and percentages also supported the preference of explicit method over the implicit one. The EFL learners claimed that they were more interested in explicit learning of pragmatic features of speech acts of request (Very Interested $=92.4 \%$ vs. $86.4 \%$ ). Despite preference implicit learning of invitation; the results of independent-samples t-test $(t=1.128, p=.262)$ indicated that the difference between two means were not statistically significant. 
Table 6

Descriptive Statistics; Interest in Learning Pragmatic Features of Speech Acts of Request by Group

\begin{tabular}{|c|c|c|c|c|c|c|c|c|}
\hline & & \multirow[t]{2}{*}{$\mathrm{N}$} & \multicolumn{2}{|c|}{$\begin{array}{l}\text { Fairly } \\
\text { Interested }\end{array}$} & \multicolumn{2}{|c|}{$\begin{array}{l}\text { Very } \\
\text { Interested }\end{array}$} & Mean & \multirow[t]{2}{*}{ Std. Deviation } \\
\hline & & & Freq. & $\%$ & Freq. & $\%$ & & \\
\hline \multirow{2}{*}{$\begin{array}{l}\text { How interested are } \\
\text { you in learning the } \\
\text { pragmatic } \\
\text { features of the } \\
\text { speech act of } \\
\text { invitations in a } \\
\text { target language? }\end{array}$} & Explicit & 66 & 5 & 7.6 & 61 & 92.4 & 3.92 & .267 \\
\hline & Implicit & 66 & 9 & 13.6 & 57 & 86.4 & 3.86 & .346 \\
\hline Independent t-test = & $128, p=$ & & & & & & & \\
\hline
\end{tabular}

\subsubsection{Usefulness of Explicit Learning of Speech Acts}

Table 7 displays the frequencies, percentages and descriptive statistics for the first four items related to "usefulness of learning speech acts" being taught using an explicit method. Based on these results it can be concluded that EFL learners believed that they were interested in explicit learning of speech acts. Since all of the students selected the "very useful" choice for all four items, means for explicit learning of pragmatic features of speech acts, invitations, apologies and request were equal to 4 . In other words, the participants unanimously agreed with the idea that explicit learning of speech acts is useful.

Table 7

Descriptive Statistics: Usefulness of Explicit Learning of Speech Acts

\begin{tabular}{|c|c|c|c|c|c|c|c|}
\hline & \multirow[b]{2}{*}{$N$} & \multicolumn{2}{|c|}{$\begin{array}{l}\text { Fairly } \\
\text { Useful }\end{array}$} & \multicolumn{2}{|c|}{ Very Useful } & \multirow[b]{2}{*}{ Mean } & \multirow[b]{2}{*}{$\begin{array}{l}\text { Std. } \\
\text { Deviation }\end{array}$} \\
\hline & & Freq. & $\%$ & Freq. & $\%$ & & \\
\hline $\begin{array}{l}\text { How useful is it to learn the pragmatic } \\
\text { features of the specific speech acts? }\end{array}$ & 66 & 0 & 0 & 66 & 100 & 4 & .00 \\
\hline $\begin{array}{l}\text { How useful is it to learn the pragmatic } \\
\text { features of the speech act of invitations in a } \\
\text { target language? }\end{array}$ & 66 & 0 & 0 & 66 & 100 & 4 & .00 \\
\hline $\begin{array}{l}\text { How useful is it to learn the pragmatic } \\
\text { features of the speech act of apologies in a } \\
\text { target language? }\end{array}$ & 66 & 0 & 0 & 66 & 100 & 4 & .00 \\
\hline $\begin{array}{l}\text { How useful is it to learn the pragmatic } \\
\text { features of the speech act of requests in a } \\
\text { target language? }\end{array}$ & 66 & 0 & 0 & 66 & 100 & 4 & .00 \\
\hline
\end{tabular}


The frequencies and percentages further supported the descriptive statistics discussed above. The results indicated that the EFL learners, without exception, believed that they were very interested in explicit learning of speech acts.

\subsubsection{Usefulness of Implicit Learning of Speech Acts}

As displayed in Table 8, the EFL learners, without opposition, believed that they implicit learning of speech acts was very useful. The mean scores for the pragmatic features of speech acts, speech acts of invitations, apologies and requests were all equal to 4 .

Table 8

Descriptive Statistics: Interest in Implicit Learning of Speech Acts

\begin{tabular}{|c|c|c|c|c|c|c|c|}
\hline & \multirow[b]{2}{*}{$\mathrm{N}$} & \multicolumn{2}{|c|}{$\begin{array}{l}\text { Fairly } \\
\text { Useful }\end{array}$} & \multicolumn{2}{|c|}{ Very Useful } & \multirow[b]{2}{*}{ Mean } & \multirow[b]{2}{*}{$\begin{array}{l}\text { Std. } \\
\text { Deviation }\end{array}$} \\
\hline & & Freq. & $\%$ & Freq. & $\%$ & & \\
\hline $\begin{array}{l}\text { How useful is it to learn the pragmatic } \\
\text { features of the specific speech acts? }\end{array}$ & 66 & 0 & 0 & 66 & 100 & 4 & .00 \\
\hline $\begin{array}{l}\text { How useful is it to learn the pragmatic } \\
\text { features of the speech act of invitations in a } \\
\text { target language? }\end{array}$ & 66 & 0 & 0 & 66 & 100 & 4 & .00 \\
\hline $\begin{array}{l}\text { How useful is it to learn the pragmatic } \\
\text { features of the speech act of apologies in a } \\
\text { target language? }\end{array}$ & 66 & 0 & 0 & 66 & 100 & 4 & .00 \\
\hline $\begin{array}{l}\text { How useful is it to learn the pragmatic } \\
\text { features of the speech act of requests in a } \\
\text { target language? }\end{array}$ & 66 & 0 & 0 & 66 & 100 & 4 & .00 \\
\hline
\end{tabular}

The frequencies and percentages further supported the descriptive statistics discussed above. The results indicated that 100 percent of EFL learners believed that the implicit learning of speech acts was useful for them.

\subsubsection{Comparing Usefulness of Explicit vs. Implicit Learning of Pragmatic Features of Speech Acts}

Table 9 compares the EFL learners' perceptions towards the explicit vs. implicit learning of pragmatic features of speech acts. The results indicated that the EFL learners, with an accord, believed explicit $($ Mean $=4)$ and implicit (Mean $=4$ ) learning of pragmatic features of speech acts were very useful. The percentages also supported this conclusion. All participants (100\%) believed that explicit and implicit learning of pragmatic features of speech acts were useful. Consequently, the results of independentsamples $t$-test indicated that there was no difference between two means $(t=0.00, p=1.00)$. 
Table 9

Descriptive Statistics; Usefulness of Learning Pragmatic Features of Speech Acts by Groups

\begin{tabular}{|c|c|c|c|c|c|c|c|c|}
\hline & & \multirow[t]{2}{*}{$\mathrm{N}$} & \multicolumn{2}{|c|}{$\begin{array}{l}\text { Fairly } \\
\text { Useful }\end{array}$} & \multicolumn{2}{|c|}{ Very Useful } & \multirow[t]{2}{*}{ Mean } & \multirow[t]{2}{*}{$\begin{array}{l}\text { Std. } \\
\text { Deviation }\end{array}$} \\
\hline & & & Freq. & $\%$ & Freq. & $\%$ & & \\
\hline \multirow{2}{*}{$\begin{array}{l}\text { How useful is it to learn the } \\
\text { pragmatic features of the } \\
\text { specific speech acts? }\end{array}$} & Explicit & 66 & 0 & 0 & 66 & 100 & 4 & .00 \\
\hline & Implicit & 66 & 0 & 0 & 66 & 100 & 4 & .00 \\
\hline
\end{tabular}

\subsubsection{Comparing Usefulness of Explicit vs. Implicit Learning of Pragmatic Features of Speech Acts of Invitations}

Table 10 compares the EFL learners' perceptions towards the usefulness of the explicit vs. implicit learning of pragmatic features of speech acts of invitations. The results indicated that the EFL learners believed that speech acts invitations were useful irrespective of the method of teaching. The mean score for both explicit and implicit learning of the pragmatic features of the speech acts of invitations were 4 . That is to say, the participants unanimously agreed that learning speech acts of invitations were very useful. The frequencies and percentages further supported this conclusion. All EFL learners $(100 \%)$ selected the "very useful" choice when asked about the usefulness of the learning of speech acts of invitation. Consequently; the results of independent-samples t-test indicated that there was no difference between two means $(t=0.00, p=1.00)$.

Table 10

Descriptive Statistics; Usefulness of Learning Pragmatic Features of Speech Acts of Invitations by Groups

\begin{tabular}{|c|c|c|c|c|c|c|c|c|}
\hline & & \multirow[t]{2}{*}{$\mathrm{N}$} & \multicolumn{2}{|c|}{ Fairly Useful } & \multicolumn{2}{|c|}{ Very Useful } & \multirow[t]{2}{*}{ Mean } & \multirow{2}{*}{$\begin{array}{l}\text { Std. } \\
\text { Deviation }\end{array}$} \\
\hline & & & Freq. & $\%$ & Freq. & $\%$ & & \\
\hline \multirow{2}{*}{$\begin{array}{l}\text { How useful is it to learn } \\
\text { the pragmatic features of } \\
\text { the speech act of } \\
\text { invitations in a target } \\
\text { language? }\end{array}$} & Explicit & 66 & 0 & 0.00 & 66 & 100 & 4 & .00 \\
\hline & Implicit & 66 & 0 & 0.00 & 66 & 100 & 4 & .00 \\
\hline Independent $\mathrm{t}$-test $=0.00, \mathrm{p}$ & 1.00 & & & & & & & \\
\hline
\end{tabular}

\subsubsection{Comparing Usefulness of Explicit vs. Implicit Learning of Pragmatic Features of Speech Acts of}




\section{Apologies}

The seventh item of the questionnaire asked EFL learners how useful they believed learning the pragmatic features of speech acts of apologies was. All 66 students believed that explicit and implicit learning of the pragmatic features of speech acts of apologies was "very useful". That was why the results displayed in Table 11 indicated that 100 percent of respondents agreed with the usefulness of the explicit vs. implicit learning of speech acts of apologies. The results of independent-samples t-test; consequently, indicated that there was no difference between two means $(t=0.00, p=1.00)$.

Table 11

Descriptive Statistics; Usefulness of Learning Pragmatic Features of Speech Acts of Apologies by Groups

\begin{tabular}{|c|c|c|c|c|c|c|c|c|}
\hline & & \multirow[t]{2}{*}{$\mathrm{N}$} & \multicolumn{2}{|c|}{ Fairly Useful } & \multicolumn{2}{|c|}{ Very Useful } & \multirow[t]{2}{*}{ Mean } & \multirow{2}{*}{$\begin{array}{l}\text { Std. } \\
\text { Deviation }\end{array}$} \\
\hline & & & Freq. & $\%$ & Freq. & $\%$ & & \\
\hline \multirow{2}{*}{$\begin{array}{l}\text { How useful is it to learn } \\
\text { the pragmatic features of } \\
\text { the speech act of } \\
\text { apologies in a target } \\
\text { language? }\end{array}$} & Explicit & 66 & 0 & 0.00 & 66 & 100 & 4 & 0.00 \\
\hline & Implicit & 66 & 0 & 0.00 & 66 & 100 & 4 & 0.00 \\
\hline Independent $t$-test $=0.00, p$ & & & & & & & & \\
\hline
\end{tabular}

\subsubsection{Comparing Usefulness of Explicit vs. Implicit Learning of Pragmatic Features of Speech Acts of Request}

Table 12 compares the EFL learners' perceptions towards the usefulness of the explicit vs. implicit learning of pragmatic features of speech acts of request. The results indicated that the EFL learners believed that speech acts of request were useful irrespective of the method of teaching. The mean score for both explicit and implicit learning of the pragmatic features of the speech acts of request were 4 . That is to say, the participants, without any opposition, agreed that learning speech acts of request were very useful. The frequencies and percentages further supported this conclusion. All EFL learners $(100 \%)$ selected the "very useful" choice when asked about the usefulness of the learning of speech acts of request. Consequently; the results of independent-samples t-test indicated that there was no difference between two means $(t=0.00, p=1.00)$. 
Table 12

Descriptive Statistics; Usefulness of Learning Pragmatic Features of Speech Acts of Request by Groups

\begin{tabular}{|c|c|c|c|c|c|c|c|c|}
\hline & & \multirow[t]{2}{*}{$\mathrm{N}$} & \multicolumn{2}{|c|}{ Fairly Useful } & \multicolumn{2}{|c|}{ Very Useful } & \multirow[t]{2}{*}{ Mean } & \multirow{2}{*}{$\begin{array}{l}\text { Std. } \\
\text { Deviation }\end{array}$} \\
\hline & & & Freq. & $\%$ & Freq. & $\%$ & & \\
\hline \multirow{2}{*}{$\begin{array}{l}\text { How useful is it to learn } \\
\text { the pragmatic features of } \\
\text { the speech act of requests } \\
\text { in a target language? }\end{array}$} & Explicit & 66 & 0 & 0.00 & 66 & 100 & 4 & 0.00 \\
\hline & Implicit & 66 & 0 & 0.00 & 66 & 100 & 4 & 0.00 \\
\hline
\end{tabular}

\subsubsection{Motivation in Explicit Learning of Speech Acts}

Items 9 to 12 of the students' questionnaire targeted how motivating it was to learn pragmatic features of speech acts in general, and also specific speech acts of invitations, apologies and requests. The following will discuss the results related to stimulation in explicit vs. implicit learning of speech acts.

Table 13 displays the frequencies, percentages and descriptive statistics for the items related to "stimulation in explicit learning of speech acts". Based on these results it can be concluded that all EFL learners believed that the explicit learning of pragmatic features of speech acts (Mean $=4$ ), speech acts of invitation (Mean $=4)$ and speech acts of requests (Mean $=4)$ were "very motivating". However, they were not unanimous on their motivation regarding the explicit learning of speech acts of apologies $($ Mean $=3.67)$. 
Table 13

Descriptive Statistics: Motivation in Explicit Learning of Speech Acts

\begin{tabular}{|c|c|c|c|c|c|c|c|}
\hline & \multirow[b]{2}{*}{$\mathrm{N}$} & \multicolumn{2}{|c|}{$\begin{array}{l}\text { Fairly } \\
\text { Motivating }\end{array}$} & \multicolumn{2}{|c|}{$\begin{array}{l}\text { Very } \\
\text { Motivating }\end{array}$} & \multirow[b]{2}{*}{ Mean } & \multirow[b]{2}{*}{$\begin{array}{l}\text { Std. } \\
\text { Deviation }\end{array}$} \\
\hline & & Freq. & $\%$ & Freq. & $\%$ & & \\
\hline $\begin{array}{l}\text { How motivating is it to learn the } \\
\text { pragmatic features of the specific speech } \\
\text { acts? }\end{array}$ & 66 & 0 & 0 & 66 & 100 & 4 & .00 \\
\hline $\begin{array}{l}\text { How motivating is it to learn the } \\
\text { pragmatic features of the speech act of } \\
\text { invitations in a target language? }\end{array}$ & 66 & 0 & 0 & 66 & 100 & 4 & .00 \\
\hline $\begin{array}{l}\text { How motivating is it to learn the } \\
\text { pragmatic features of the speech act of } \\
\text { apologies in a target language? }\end{array}$ & 66 & 22 & 33.3 & 44 & 66.7 & 3.67 & .475 \\
\hline $\begin{array}{l}\text { How motivating is it to learn the } \\
\text { pragmatic features of the speech act of } \\
\text { requests in a target language? }\end{array}$ & 66 & 0 & 0 & 66 & 100 & 4 & .00 \\
\hline
\end{tabular}

Naturally, 100 percent of respondents believed that explicit learning of speech acts in general and speech acts of invitations and request were "very motivating"; however, 33.3 percent of respondents believed that explicit learning of speech acts of apologies was "fairly motivating", and another 66.7 percent found explicit learning of speech acts of apologies was "very motivating".

\subsubsection{Motivation in Implicit Learning of Speech Acts}

As displayed in Table 14, the EFL learners, without opposition, believed that they implicit learning of speech acts in general, and also speech acts of invitations and request were "very motivating". The mean scores for the pragmatic features of speech acts, speech acts of invitations and requests were all equal to 4 . However, the EFL learners were not unanimous in implicit learning of speech acts of apologies. Their mean score was 3.80 . 
Table 14

Descriptive Statistics: Motivation in Implicit Learning of Speech Acts

\begin{tabular}{|lllllllll|}
\hline & N & Freq. & $\%$ & Freq. & $\%$ & Mean & $\begin{array}{l}\text { Std. } \\
\text { Deviation }\end{array}$ \\
\hline & 66 & 0 & 0 & 66 & 100 & 4 & .00 \\
\hline $\begin{array}{l}\text { How motivating is it to learn the } \\
\text { pragmatic features of the specific speech } \\
\text { acts? }\end{array}$ & & & & & & & \\
\hline $\begin{array}{l}\text { How motivating is it to learn the } \\
\text { pragmatic features of the speech act of } \\
\text { invitations in a target language? }\end{array}$ & 66 & 0 & 0 & 66 & 100 & 4 & .00 \\
$\begin{array}{l}\text { How motivating is it to learn the } \\
\text { pragmatic features of the speech act of } \\
\text { apologies in a target language? }\end{array}$ & 66 & 13 & 19.7 & 53 & 80.3 & 3.80 & .401 \\
$\begin{array}{l}\text { How motivating is it to learn the } \\
\text { pragmatic features of the speech act of } \\
\text { requests in a target language? }\end{array}$ & 66 & 0 & 0 & 66 & 100 & 4 & .00 \\
\hline
\end{tabular}

Consequently, all respondents (100\%) believed that implicit learning of speech acts in general and speech acts of invitations and request were "very motivating"; however, 19.7 percent of respondents believed that implicit learning of speech acts of apologies was "fairly motivating", and another 80.3 percent found explicit learning of speech acts of apologies was "very motivating".

\subsubsection{Comparing Motivation in Explicit vs. Implicit Learning of Pragmatic Features of Speech Acts}

Table 15 compares the EFL learners' perceptions towards the motivation in explicit vs. implicit learning of pragmatic features of speech acts. The results indicated that the EFL learners, with an accord, believed explicit (Mean $=4)$ and implicit (Mean $=4$ ) learning of pragmatic features of speech acts were "very motivating". The percentages also supported this conclusion. All participants (100\%) believed that explicit and implicit learning of pragmatic features of speech acts were motivating. Consequently, the results of independent-samples $t$-test indicated that there was no difference between two means $(t=0.00$, $p=1.00)$. 
Table 15

Descriptive Statistics; Motivation in Learning Pragmatic Features of Speech Acts by Groups

\begin{tabular}{|c|c|c|c|c|c|c|c|c|}
\hline & & \multirow[t]{2}{*}{$\mathrm{N}$} & \multicolumn{2}{|c|}{$\begin{array}{l}\text { Fairly } \\
\text { Motivating }\end{array}$} & \multicolumn{2}{|c|}{$\begin{array}{l}\text { Very } \\
\text { Motivating }\end{array}$} & \multirow[t]{2}{*}{ Mean } & \multirow[t]{2}{*}{$\begin{array}{l}\text { Std. } \\
\text { Deviation }\end{array}$} \\
\hline & & & Freq. & $\%$ & Freq. & $\%$ & & \\
\hline \multirow{2}{*}{$\begin{array}{l}\text { How motivating is it to learn } \\
\text { the pragmatic features of the } \\
\text { specific speech acts? }\end{array}$} & Explicit & 66 & 0 & 0 & 66 & 100 & 4 & .00 \\
\hline & Implicit & 66 & 0 & 0 & 66 & 100 & 4 & .00 \\
\hline
\end{tabular}

\subsubsection{Comparing Motivation in Explicit vs. Implicit Learning of Pragmatic Features of Speech Acts of Invitations}

Table 16 compares the EFL learners' perceptions towards the motivation in the explicit vs. implicit learning of pragmatic features of speech acts of invitations. The results indicated that the EFL learners believed that speech acts invitations were motivating irrespective of the method of teaching. The mean score for both motivation in explicit and implicit learning of the pragmatic features of the speech acts of invitations were 4 . That is to say, the participants unanimously agreed that learning speech acts of invitations were "very motivating". The frequencies and percentages further supported this conclusion. All EFL learners (100\%) selected the "very motivating" choice when asked about the motivation in the learning of speech acts of invitation. Consequently; the results of independent-samples t-test indicated that there was no difference between two means $(t=0.00, p=1.00)$.

Table 16

Descriptive Statistics; Motivation in Learning Pragmatic Features of Speech Acts of Invitations by Groups

\begin{tabular}{|c|c|c|c|c|c|c|c|c|}
\hline & & \multirow[t]{2}{*}{$\mathrm{N}$} & \multicolumn{2}{|c|}{$\begin{array}{l}\text { Fairly } \\
\text { Motivating }\end{array}$} & \multicolumn{2}{|c|}{$\begin{array}{l}\text { Very } \\
\text { Motivating }\end{array}$} & \multirow[t]{2}{*}{ Mean } & \multirow[t]{2}{*}{$\begin{array}{l}\text { Std. } \\
\text { Deviation }\end{array}$} \\
\hline & & & Freq. & $\%$ & Freq. & $\%$ & & \\
\hline \multirow{2}{*}{$\begin{array}{l}\text { How motivating is it to } \\
\text { learn the pragmatic } \\
\text { features of the speech act } \\
\text { of invitations in a target } \\
\text { language? }\end{array}$} & Explicit & 66 & 0 & 0.00 & 66 & 100 & 4 & .00 \\
\hline & Implicit & 66 & 0 & 0.00 & 66 & 100 & 4 & .00 \\
\hline \multicolumn{9}{|c|}{ Independent t-test $=0.00, p=1.00$} \\
\hline
\end{tabular}




\subsubsection{Comparing Motivation in Explicit vs. Implicit Learning of Pragmatic Features of Speech Acts of Apologies}

The results displayed in Table 17 indicated that the EFL learners believed that implicit learning of speech acts of apologies was more motivating (Mean = 3.80) than the using an explicit method (Mean = 3.67). The frequencies and percentages further supported EFL learners' preference over an implicit method. The results showed that 19.7 percent of respondents believed that implicit learning of apologies was "fairly motivating", and another $80.3 \%$ agreed with the idea that implicit learning of apologies was "very motivating"; while the percentages for the explicit learning were 33.3 and 66.7. Despite the differences discussed above, the results of independent-samples t-test indicated that there was not any significant difference between two means $(t=1.78, p=.077)$.

Table 17

Descriptive Statistics; Motivation in Learning Pragmatic Features of Speech Acts of Apologies by Groups

\begin{tabular}{|c|c|c|c|c|c|c|c|c|}
\hline & & \multirow[t]{2}{*}{$N$} & \multicolumn{2}{|c|}{$\begin{array}{l}\text { Fairly } \\
\text { Motivating }\end{array}$} & \multicolumn{2}{|c|}{$\begin{array}{l}\text { Very } \\
\text { Motivating }\end{array}$} & \multirow[t]{2}{*}{ Mean } & \multirow[t]{2}{*}{$\begin{array}{l}\text { Std. } \\
\text { Deviation }\end{array}$} \\
\hline & & & Freq. & $\%$ & Freq. & $\%$ & & \\
\hline \multirow{2}{*}{$\begin{array}{l}\text { How motivating is it to } \\
\text { learn the pragmatic } \\
\text { features of the speech act } \\
\text { of apologies in a target } \\
\text { language? }\end{array}$} & Explicit & 66 & 22 & 33.3 & 44 & 66.7 & 3.67 & .475 \\
\hline & Implicit & 66 & 13 & 19.7 & 53 & 80.3 & 3.80 & 0.401 \\
\hline Independent t-test $=1.78, \mathrm{p}$ & 0.077 & & & & & & & \\
\hline
\end{tabular}

\subsubsection{Comparing Motivation in Explicit vs. Implicit Learning of Pragmatic Features of Speech Acts of Request}

Table 18 compares the EFL learners' perceptions towards the motivation in the explicit vs. implicit learning of pragmatic features of speech acts of request. The results indicated that the EFL learners believed that learning speech acts of request was motivating irrespective of the method of teaching. The mean score for both explicit and implicit learning of the pragmatic features of the speech acts of request were 4. That is to say, the participants, without any opposition, agreed that learning speech acts of request were "very motivating". The frequencies and percentages further supported this conclusion. All EFL learners (100\%) selected the "very motivating" choice when asked about the motivation in the learning of speech acts of request. Consequently; the results of independent-samples t-test indicated that there was no difference between two means $(t=0.00, p=1.00)$. 
Table 18

Descriptive Statistics; Motivation in Learning Pragmatic Features of Speech Acts of Request by Groups

\begin{tabular}{|c|c|c|c|c|c|c|c|c|}
\hline & & \multirow[t]{2}{*}{$\mathrm{N}$} & \multicolumn{2}{|c|}{$\begin{array}{l}\text { Fairly } \\
\text { Motivating }\end{array}$} & \multicolumn{2}{|c|}{$\begin{array}{l}\text { Very } \\
\text { Motivating }\end{array}$} & \multirow[t]{2}{*}{ Mean } & \multirow[t]{2}{*}{$\begin{array}{l}\text { Std. } \\
\text { Deviation }\end{array}$} \\
\hline & & & Freq. & $\%$ & Freq. & $\%$ & & \\
\hline \multirow{2}{*}{$\begin{array}{l}\text { How motivating is it to } \\
\text { learn the pragmatic } \\
\text { features of the speech act } \\
\text { of requests in a target } \\
\text { language? }\end{array}$} & Explicit & 66 & 0 & 0.00 & 66 & 100 & 4 & 0.00 \\
\hline & Implicit & 66 & 0 & 0.00 & 66 & 100 & 4 & 0.00 \\
\hline \multicolumn{9}{|c|}{ Independent t-test $=0.00, p=1.00$} \\
\hline
\end{tabular}

\subsubsection{Difficulty of Explicit Learning of Speech Acts}

Items 13 to 16 of the students' questionnaire targeted how difficult it was to learn pragmatic features of speech acts in general, and also specific speech acts of invitations, apologies and requests. Unlike all results discussed so far, the EFL learners' perceptions towards the difficulty of explicit and implicit learning of speech acts show significant differences between the two methods; whose results are discussed below.

Table 19 displays the frequencies, percentages and descriptive statistics for the items related to difficulty of explicit learning of speech acts, and speech acts of invitations, apologies and requests. Based on these results it can be concluded that majority of the EFL learners (60.6\%) believed that it was "not very difficult" to learn speech acts. Another 39.4 percent claimed that it was "not at all difficult" to learn speech acts. The mean for the students' perception on difficulty of learning speech acts was 1.91 . 
Table 19

Descriptive Statistics: Motivation in Explicit Learning of Speech Acts

\begin{tabular}{|c|c|c|c|c|c|c|c|}
\hline & \multirow[b]{2}{*}{$\mathrm{N}$} & \multicolumn{2}{|c|}{$\begin{array}{l}\text { Not at all } \\
\text { Difficult }\end{array}$} & \multicolumn{2}{|c|}{$\begin{array}{l}\text { Not very } \\
\text { Difficult }\end{array}$} & \multirow[b]{2}{*}{ Mean } & \multirow[b]{2}{*}{$\begin{array}{l}\text { Std. } \\
\text { Deviation }\end{array}$} \\
\hline & & Freq. & $\%$ & Freq. & $\%$ & & \\
\hline $\begin{array}{l}\text { How difficult is it to learn the pragmatic } \\
\text { features of the specific speech acts? }\end{array}$ & 66 & 26 & 39.4 & 40 & 60.6 & 1.61 & .492 \\
\hline $\begin{array}{l}\text { How difficult is it to learn the pragmatic } \\
\text { features of the speech act of invitations } \\
\text { in a target language? }\end{array}$ & 66 & 26 & 39.4 & 40 & 60.6 & 1.61 & .492 \\
\hline $\begin{array}{l}\text { How difficult is it to learn the pragmatic } \\
\text { features of the speech act of apologies } \\
\text { in a target language? }\end{array}$ & 66 & 26 & 39.4 & 40 & 60.6 & 1.61 & .492 \\
\hline $\begin{array}{l}\text { How difficult is it to learn the pragmatic } \\
\text { features of the speech act of requests in } \\
\text { a target language? }\end{array}$ & 66 & 26 & 39.4 & 40 & 60.6 & 1.61 & .492 \\
\hline
\end{tabular}

\subsubsection{Difficulty of Implicit Learning of Speech Acts}

The results displayed in Table 20 are opposite to the ones discussed above for the explicit learning of speech acts. Majority of the EFL learners (65.2\%) believed that it was "fairly difficult" to implicitly learn pragmatic features of specific speech acts. Another 34.8 percent estimated implicit learning of pragmatic features of specific speech acts as "very difficult". Their mean score was 3.35.

Regarding the implicit learning of speech acts of invitations, the results indicated that majority of the EFL learners (98.5\%) believed that it was "fairly difficult" to learn pragmatic features of speech acts of invitations implicitly. Another 1.5 percent estimated implicit learning of pragmatic features of speech acts of invitation as "very difficult". Their mean score was 3.02 . 
Table 20

Descriptive Statistics: Difficulty of Implicit Learning of Speech Acts

\begin{tabular}{|c|c|c|c|c|c|c|c|}
\hline & \multirow[b]{2}{*}{$\mathrm{N}$} & \multicolumn{2}{|c|}{$\begin{array}{l}\text { Fairly } \\
\text { Difficult }\end{array}$} & \multicolumn{2}{|c|}{ Very Difficult } & \multirow[b]{2}{*}{ Mean } & \multirow[b]{2}{*}{$\begin{array}{l}\text { Std. } \\
\text { Deviation }\end{array}$} \\
\hline & & Freq. & $\%$ & Freq. & $\%$ & & \\
\hline $\begin{array}{l}\text { How difficult is it to learn the pragmatic } \\
\text { features of the specific speech acts? }\end{array}$ & 66 & 43 & 65.2 & 23 & 34.8 & 3.35 & .480 \\
\hline $\begin{array}{l}\text { How difficult is it to learn the pragmatic } \\
\text { features of the speech act of invitations } \\
\text { in a target language? }\end{array}$ & 66 & 65 & 98.5 & 1 & 1.5 & 3.02 & .123 \\
\hline $\begin{array}{l}\text { How difficult is it to learn the pragmatic } \\
\text { features of the speech act of apologies } \\
\text { in a target language? }\end{array}$ & 66 & 21 & 31.8 & 44 & 66.7 & 1.70 & .495 \\
\hline $\begin{array}{l}\text { How difficult is it to learn the pragmatic } \\
\text { features of the speech act of requests in } \\
\text { a target language? }\end{array}$ & 66 & 53 & 80.3 & 13 & 19.7 & 3.20 & .401 \\
\hline
\end{tabular}

The results displayed in Table 4.30 also indicated that majority of the EFL learners (66.7\%) believed that it was "very difficult" to learn pragmatic features of speech acts of apologies implicitly. Another 31.8 percent estimated implicit learning of pragmatic features of speech acts of apologies as "fairly difficult". Their mean score was 1.70 .

Regarding the implicit learning of speech acts of request, the results indicated that majority of the EFL learners (80.3\%) believed that it was "fairly difficult" to learn pragmatic features of speech acts of request implicitly. Another 19.7 percent estimated implicit learning of pragmatic features of speech acts of requests as "very difficult". Their mean score was 3.20.

\subsubsection{Comparing Difficulty of Explicit vs. Implicit Learning of Pragmatic Features of Speech Acts}

Table 21 compares the EFL learners' perceptions towards the difficulty of explicit vs. implicit learning of pragmatic features of specific speech acts. The results indicated that the EFL learners believed that it was easier to learn pragmatic features of specific speech acts explicitly (Mean $=1.61 \mathrm{vs}$. Mean $=3.35$ ). The percentages also supported this conclusion; while EFL learners believed that it was "not at all difficult" (39.4\%), and "not very difficult" (60.6\%) to learn specific speech acts explicitly, majority of them believed that it was "fairly difficult" (65.2\%) and "very difficult" (34.8\%) to learn specific speech acts implicitly. The results of independent-samples t-test $(t=20.58, p=.000)$ indicated that it was significantly easier to learn specific speech acts explicitly. 
Table 21

Descriptive Statistics; Difficulty of Learning Pragmatic Features of Speech Acts by Groups

\begin{tabular}{|c|c|c|c|c|c|c|c|}
\hline & & $\begin{array}{l}\text { Not at } \\
\text { all }\end{array}$ & $\begin{array}{l}\text { Not } \\
\text { very }\end{array}$ & $\begin{array}{l}\text { Fairly } \\
\text { difficult }\end{array}$ & $\begin{array}{l}\text { Very } \\
\text { Difficult }\end{array}$ & Mean & $S D$ \\
\hline \multirow{4}{*}{$\begin{array}{l}\text { How difficult is it to learn the } \\
\text { pragmatic features of the } \\
\text { specific speech acts? }\end{array}$} & Explicit & 26 & 40 & \multirow[t]{2}{*}{0} & \multirow[t]{2}{*}{0} & \multirow[t]{2}{*}{1.61} & \multirow[t]{2}{*}{.492} \\
\hline & & $(39.4 \%)$ & $(60.6 \%)$ & & & & \\
\hline & \multirow[t]{2}{*}{ Implicit } & \multirow[t]{2}{*}{0} & \multirow[t]{2}{*}{0} & 43 & 23 & \multirow[t]{2}{*}{3.35} & \multirow[t]{2}{*}{.480} \\
\hline & & & & $(65.2 \%)$ & (34.8\%) & & \\
\hline
\end{tabular}

\subsubsection{Comparing Difficulty of Explicit vs. Implicit Learning of Pragmatic Features of Speech Acts of Invitations}

Table 22 compares the EFL learners' perceptions towards the difficulty of explicit vs. implicit learning of pragmatic features of speech acts of invitations. The results indicated that the EFL learners believed that it was easier to learn pragmatic features of speech acts of invitations explicitly (Mean $=1.61 \mathrm{vs}$. Mean $=$ 3.02). The percentages also supported this conclusion; while EFL learners believed that it was "not at all difficult" (39.4\%), and "not very difficult" $(60.6 \%)$ to learn speech acts of invitations explicitly, almost all of them believed that it was "fairly difficult" (98.5\%) and "very difficult" $(1.5 \%)$ to learn speech acts of invitations implicitly. The results of independent-samples t-test $(t=22.55, p=.000)$ indicated that it was significantly easier to learn specific speech acts explicitly.

Table 22

Descriptive Statistics; Difficulty of Learning Pragmatic Features of Speech Acts of Invitations by Groups

\begin{tabular}{|c|c|c|c|c|c|c|c|}
\hline & & $\begin{array}{l}\text { Not at } \\
\text { all }\end{array}$ & $\begin{array}{l}\text { Not } \\
\text { very }\end{array}$ & $\begin{array}{l}\text { Fairly } \\
\text { difficult }\end{array}$ & $\begin{array}{l}\text { Very } \\
\text { Difficult }\end{array}$ & Mean & SD \\
\hline \multirow{4}{*}{$\begin{array}{l}\text { How difficult is it to learn } \\
\text { the pragmatic features of } \\
\text { the speech act of } \\
\text { invitations in a target } \\
\text { language? }\end{array}$} & Explicit & 26 & 40 & 0 & 0 & 1.61 & .492 \\
\hline & & $(39.4 \%)$ & $(60.6 \%)$ & & & & \\
\hline & Implicit & 0 & 0 & 65 & 1 & 3.02 & .123 \\
\hline & & & & (98.5\%) & $(1.5 \%)$ & & \\
\hline
\end{tabular}

\subsubsection{Comparing Difficulty of Explicit vs. Implicit Learning of Pragmatic Features of Speech Acts of Apologies}


The results displayed in Table 23 indicated that the EFL learners believed that explicit and implicit learning of speech acts of apologies was almost equally difficult (Mean $=1.61 \mathrm{vs}$. Mean $=1.70$ ). The frequencies and percentages further supported the results. Majority of the EFL learners (60.6\%) believed that explicit learning of speech acts of apologies was "not very difficult". The percentage for the implicit learning of apologies was $66.7 \%$. The participants almost equally believed that it was "not at all difficult" to learn speech acts of apologies explicitly (39.4\%) nor implicitly (31.8). Despite these minor differences, the results of independent-samples t-test indicated that there was not any significant difference between two means $(t=1.05, p=.292)$.

Table 23

Descriptive Statistics; Difficulty of Learning Pragmatic Features of Speech Acts of Apologies by Groups

\begin{tabular}{|c|c|c|c|c|c|c|c|c|}
\hline & & \multirow[t]{2}{*}{$N$} & \multicolumn{2}{|c|}{$\begin{array}{l}\text { No at all } \\
\text { difficult }\end{array}$} & \multicolumn{2}{|c|}{$\begin{array}{l}\text { Not very } \\
\text { difficult }\end{array}$} & \multirow[t]{2}{*}{ Mean } & \multirow[t]{2}{*}{$\begin{array}{l}\text { Std. } \\
\text { Deviation }\end{array}$} \\
\hline & & & Freq. & $\%$ & Freq. & $\%$ & & \\
\hline \multirow{2}{*}{$\begin{array}{l}\text { How difficult is it to learn } \\
\text { the pragmatic features of } \\
\text { the speech act of } \\
\text { apologies in a target } \\
\text { language? }\end{array}$} & Explicit & 66 & 26 & 39.4 & 40 & 60.6 & 1.61 & .492 \\
\hline & Implicit & 66 & 21 & 31.9 & 44 & 66.7 & 1.70 & .495 \\
\hline Independent t-test $=1.78, \mathrm{p}$ & 0.077 & & & & & & & \\
\hline
\end{tabular}

\subsubsection{Comparing Difficulty of Explicit vs. Implicit Learning of Pragmatic Features of Speech Acts of Request}

Table 24 compares the EFL learners' perceptions towards the difficulty of explicit vs. implicit learning of pragmatic features of speech acts of requests. The results indicated that the EFL learners believed that it was easier to learn pragmatic features of speech acts of requests explicitly (Mean $=1.61 \mathrm{vs}$. Mean $=$ 3.20). The percentages also supported this conclusion; while EFL learners believed that it was "not at all difficult" (39.4\%), and "not very difficult" (60.6\%) to learn speech acts of requests explicitly, majority of them believed that it was "fairly difficult" (80.3\%) and "very difficult" (19.7\%) to learn speech acts of requests implicitly. The results of independent-samples t-test $(t=20.35, p=.000)$ indicated that it was significantly easier to learn specific speech acts explicitly. 
Table 24

Descriptive Statistics; Difficulty of Learning Pragmatic Features of Speech Acts of Request by Groups

\begin{tabular}{|llllllll|}
\hline & $\begin{array}{l}\text { Not at } \\
\text { all }\end{array}$ & $\begin{array}{l}\text { Not } \\
\text { very }\end{array}$ & $\begin{array}{l}\text { Fairly } \\
\text { difficult }\end{array}$ & $\begin{array}{l}\text { Very } \\
\text { Difficult }\end{array}$ & Mean & SD \\
\hline $\begin{array}{l}\text { How difficult is it to learn } \\
\text { the pragmatic features of } \\
\text { the speech act of } \\
\text { requests in a target } \\
\text { language? }\end{array}$ & Explicit & 26 & 40 & 0 & 0 & 1.61 & .492 \\
\cline { 2 - 8 } & Implicit & 0 & 0 & 53 & 13 & 3.20 & .401 \\
\hline Independent t-test $=20.35, \mathrm{p}=.000$ & & & & $(80.4 \%)$ & & & \\
\hline
\end{tabular}

\subsubsection{Importance of Explicit Learning of Speech Acts}

Items 17 to 20 of the students' questionnaire targeted how important it was to learn pragmatic features of speech acts in general, and also specific speech acts of invitations, apologies and requests. The following will discuss the results related to importance of explicit vs. implicit learning of speech acts.

Table 25 displays the frequencies, percentages and descriptive statistics for the items related to "importance of explicit learning of speech acts". Based on these results it can be concluded that majority EFL learners believed that the explicit learning of pragmatic features of speech acts (Mean $=3.88$ ), speech acts of invitation (Mean $=3.88)$, speech acts of apologies (Mean $=3.88$ ) and speech acts of requests (Mean $=3.89$ ) were important. 
Table 25

Descriptive Statistics: Importance of Explicit Learning of Speech Acts

\begin{tabular}{|lllllllll|}
\hline & N & Freq. & $\%$ & Freq. & $\%$ & Mean & $\begin{array}{l}\text { Std. } \\
\text { Deviation }\end{array}$ \\
\hline & 66 & 8 & 12.1 & 58 & 87.9 & 3.88 & .329 \\
\hline $\begin{array}{l}\text { How important is it to learn the } \\
\text { pragmatic features of the specific speech } \\
\text { acts? }\end{array}$ & & & & & & & \\
\hline $\begin{array}{l}\text { How important is it to learn the } \\
\text { pragmatic features of the speech act of } \\
\text { invitations in a target language? }\end{array}$ & 66 & 8 & 12.1 & 58 & 87.9 & 3.88 & .329 \\
\hline $\begin{array}{l}\text { How important is it to learn the } \\
\text { pragmatic features of the speech act of } \\
\text { apologies in a target language? }\end{array}$ & 66 & 8 & 12.1 & 58 & 87.9 & 3.88 & .329 \\
$\begin{array}{l}\text { How important is it to learn the } \\
\text { pragmatic features of the speech act of } \\
\text { requests in a target language? }\end{array}$ & 66 & 7 & 10.6 & 59 & 89.4 & 3.89 & .310 \\
\hline
\end{tabular}

The frequencies and percentages further supported the descriptive results discussed above. Regarding the explicit learning of pragmatic features of specific speech acts, and speech acts of invitations and apologies, 87.9 percent of respondents believed that they were "very important". Furthermore, another $12.1 \%$ attached "fairly important" to these speech acts.

However, the percentages for the explicit learning of speech acts of requests were a bit different. Majority of the EFL learners; i.e. 89.4 percent claimed that explicit learning of speech acts of requests was "very important", and another 10.6 percent estimated it as "fairly important".

\subsubsection{Importance of Implicit Learning of Speech Acts}

Table 26 displays the frequencies, percentages and descriptive statistics for the items related to "importance of implicit learning of speech acts". Based on these results it can be concluded that majority EFL learners believed that the explicit learning of pragmatic features of speech acts (Mean $=3.80$ ), speech acts of invitation (Mean $=3.80)$, speech acts of apologies $($ Mean $=3.80)$ and speech acts of requests (Mean $=3.80$ ) were important. 
Table 26

Descriptive Statistics: Importance of Implicit Learning of Speech Acts

\begin{tabular}{|lllllllll|}
\hline & N & Freq. & $\%$ & Freq. & $\%$ & Mean & $\begin{array}{l}\text { Std. } \\
\text { Deviation }\end{array}$ \\
\hline & 66 & 13 & 19.7 & 53 & 80.3 & 3.80 & .401 \\
\hline $\begin{array}{l}\text { How important is it to learn the } \\
\text { pragmatic features of the specific speech } \\
\text { acts? }\end{array}$ & & & & & & & \\
$\begin{array}{l}\text { How important is it to learn the } \\
\text { pragmatic features of the speech act of } \\
\text { invitations in a target language? }\end{array}$ & 66 & 13 & 19.7 & 53 & 80.3 & 3.80 & .401 \\
\hline $\begin{array}{l}\text { How important is it to learn the } \\
\text { pragmatic features of the speech act of } \\
\text { apologies in a target language? }\end{array}$ & 66 & 13 & 19.7 & 53 & 80.3 & 3.80 & .401 \\
$\begin{array}{l}\text { How important is it to learn the } \\
\text { lmagmatic features of the speech act of } \\
\text { requests in a target language? }\end{array}$ & 66 & 13 & 19.7 & 53 & 80.3 & 3.80 & .401 \\
\hline
\end{tabular}

The frequencies and percentages further supported the descriptive results discussed above. Regarding the implicit learning of pragmatic features of specific speech acts, and speech acts of invitations, apologies and requests, 80.3 percent of respondents believed that they were "very important"; and another $19.7 \%$ attached "fairly important" to these speech acts.

\subsubsection{Comparing Importance of Explicit vs. Implicit Learning of Pragmatic Features of Speech Acts}

Table 27 compares the EFL learners' perceptions towards the importance of explicit vs. implicit learning of pragmatic features of specific speech acts. The results indicated that the EFL learners believed explicit learning of specific speech acts (Mean $=3.88$ ) was more important than its implicit method (Mean = 3.80). The percentages also supported this conclusion. A higher percentage of participants $(87.9 \%)$ believed that explicit learning of pragmatic features of specific speech acts were "very important", while the same percentage for the implicit method was 80.3. Despite these minor differences, the results of independent-samples $t$-test indicated that there was no difference between two means $(t=1.18, p=.237)$. 
Table 27

Descriptive Statistics; Importance of Learning Pragmatic Features of Speech Acts by Groups

\begin{tabular}{|c|c|c|c|c|c|c|c|c|}
\hline & & \multirow[t]{2}{*}{$\mathrm{N}$} & \multicolumn{2}{|c|}{$\begin{array}{l}\text { Fairly } \\
\text { Important }\end{array}$} & \multicolumn{2}{|c|}{$\begin{array}{l}\text { Very } \\
\text { Important }\end{array}$} & \multirow[t]{2}{*}{ Mean } & \multirow[t]{2}{*}{$\begin{array}{l}\text { Std. } \\
\text { Deviation }\end{array}$} \\
\hline & & & Freq. & $\%$ & Freq. & $\%$ & & \\
\hline \multirow{2}{*}{$\begin{array}{l}\text { How important is it to } \\
\text { learn the pragmatic } \\
\text { features of the specific } \\
\text { speech acts? }\end{array}$} & Explicit & 66 & 8 & 12.1 & 58 & 87.9 & 3.88 & .329 \\
\hline & Implicit & 66 & 13 & 19.7 & 53 & 80.3 & 3.80 & .401 \\
\hline Independent t-test $=1.18$ & .237 & & & & & & & \\
\hline
\end{tabular}

\subsubsection{Comparing Importance of Explicit vs. Implicit Learning of Pragmatic Features of Speech Acts of Invitations}

Table 28 compares the EFL learners' perceptions towards the importance of explicit vs. implicit learning of pragmatic features of speech acts of invitation. The results indicated that the EFL learners believed explicit learning of speech acts of invitation (Mean $=3.88$ ) was more important than its implicit method (Mean $=3.80)$. The percentages also supported this conclusion. A higher percentage of participants (87.9 $\%)$ believed that explicit learning of pragmatic features of speech acts of invitations were "very important", while the same percentage for the implicit method was 80.3. Despite these minor differences, the results of independent-samples $t$-test indicated that there was no difference between two means $(t=$ $1.18, p=.237)$.

Table 28

Descriptive Statistics; Importance of Learning Pragmatic Features of Speech Acts of Invitations by Groups

\begin{tabular}{|c|c|c|c|c|c|c|c|c|}
\hline & & \multirow[t]{2}{*}{$\mathrm{N}$} & \multicolumn{2}{|c|}{$\begin{array}{l}\text { Fairly } \\
\text { Important }\end{array}$} & \multicolumn{2}{|c|}{$\begin{array}{l}\text { Very } \\
\text { Important }\end{array}$} & \multirow[t]{2}{*}{ Mean } & \multirow[t]{2}{*}{$\begin{array}{l}\text { Std. } \\
\text { Deviatior }\end{array}$} \\
\hline & & & Freq. & $\%$ & Freq. & $\%$ & & \\
\hline \multirow{2}{*}{$\begin{array}{l}\text { How important is it to } \\
\text { learn the pragmatic } \\
\text { features of the speech act } \\
\text { of invitations in a target } \\
\text { language? }\end{array}$} & Explicit & 66 & 8 & 12.1 & 58 & 87.9 & 3.88 & .329 \\
\hline & Implicit & 66 & 13 & 19.7 & 53 & 80.3 & 3.80 & .401 \\
\hline Independent $t$-test $=0.00, p$ & 1.00 & & & & & & & \\
\hline
\end{tabular}




\subsubsection{Comparing Importance of Explicit vs. Implicit Learning of Pragmatic Features of Speech Acts of Apologies}

Table 29 compares the EFL learners' perceptions towards the importance of explicit vs. implicit learning of pragmatic features of speech acts of apologies. The results indicated that the EFL learners believed explicit learning of speech acts of apologies (Mean $=3.88$ ) was more important than its implicit method (Mean $=3.80)$. The percentages also supported this conclusion. A higher percentage of participants (87.9 $\%$ ) believed that explicit learning of pragmatic features of speech acts of apologies were "very important", while the same percentage for the implicit method was 80.3. Despite these minor differences, the results of independent-samples t-test indicated that there was no difference between two means $(t=1.18, p=$ .237).

Table 29

Descriptive Statistics; Importance of Learning Pragmatic Features of Speech Acts of Apologies by Groups

\begin{tabular}{|c|c|c|c|c|c|c|c|c|}
\hline & & \multirow[t]{2}{*}{$\mathrm{N}$} & \multicolumn{2}{|c|}{$\begin{array}{l}\text { Fairly } \\
\text { Important }\end{array}$} & \multicolumn{2}{|c|}{$\begin{array}{l}\text { Very } \\
\text { Important }\end{array}$} & \multirow[t]{2}{*}{ Mean } & \multirow[t]{2}{*}{$\begin{array}{l}\text { Std. } \\
\text { Deviation }\end{array}$} \\
\hline & & & Freq. & $\%$ & Freq. & $\%$ & & \\
\hline \multirow{2}{*}{$\begin{array}{l}\text { How important is it to } \\
\text { learn the pragmatic } \\
\text { features of the speech act } \\
\text { of apologies in a target } \\
\text { language? }\end{array}$} & Explicit & 66 & 8 & 12.1 & 58 & 87.9 & 3.88 & .329 \\
\hline & Implicit & 66 & 13 & 19.7 & 53 & 80.3 & 3.80 & .401 \\
\hline Independent t-test $=1.78$, & 077 & & & & & & & \\
\hline
\end{tabular}

\subsubsection{Comparing Importance of Explicit vs. Implicit Learning of Pragmatic Features of Speech Acts of Request}

Table 30 compares the EFL learners' perceptions towards the importance of explicit vs. implicit learning of pragmatic features of speech acts of requests. The results indicated that the EFL learners believed explicit learning of speech acts of invitation (Mean $=3.89$ ) was more important than its implicit method (Mean $=3.80)$. The percentages also supported this conclusion. A higher percentage of participants (89.4 $\%)$ believed that explicit learning of pragmatic features of speech acts of apologies were "very important", while the same percentage for the implicit method was 80.3. Despite these minor differences, the results of independent-samples $t$-test indicated that there was no difference between two means $(t=1.45, p=$ $.077)$. 
Table 30

Descriptive Statistics; Importance of Learning Pragmatic Features of Speech Acts of Request by Groups

\begin{tabular}{|c|c|c|c|c|c|c|c|c|}
\hline & & \multirow[t]{2}{*}{$\mathrm{N}$} & \multicolumn{2}{|c|}{$\begin{array}{l}\text { Fairly } \\
\text { Important }\end{array}$} & \multicolumn{2}{|c|}{$\begin{array}{l}\text { Very } \\
\text { Important }\end{array}$} & \multirow[t]{2}{*}{ Mean } & \multirow[t]{2}{*}{$\begin{array}{l}\text { Std. } \\
\text { Deviatior }\end{array}$} \\
\hline & & & Freq. & $\%$ & Freq. & $\%$ & & \\
\hline \multirow{2}{*}{$\begin{array}{l}\text { How important is it to } \\
\text { learn the pragmatic } \\
\text { features of the speech act } \\
\text { of requests in a target } \\
\text { language? }\end{array}$} & Explicit & 66 & 7 & 10.6 & 59 & 89.4 & 3.89 & .310 \\
\hline & Implicit & 66 & 13 & 19.7 & 53 & 80.3 & 3.80 & .401 \\
\hline Independent t-test $=0.00, p$ & .00 & & & & & & & \\
\hline
\end{tabular}

\subsubsection{Important Skills to be Taught in English Classes}

Item 21 asked EFL learners what the most important topics/skills are to leaner in English classes. Based on the results displayed in Table 31 it can be concluded that majority of the respondents believed that "grammar and speaking" were the most important topics/skills to be learnt in English classes both explicitly (83.3\%) and implicitly (74.2\%). This was followed by "pragmatics and grammar"; i.e. $16.7 \%$ explicitly and $25.8 \%$ implicitly. None of the respondents attached importance to "vocabulary \& reading" and "listening and writing".

Table 31

Frequencies and Percentages of Important Topics/Skills to be Learnt in English Classes

What do you think is important to learn in English class?

Total

$\begin{array}{llll}\text { Grammar } & \begin{array}{l}\text { Vocabulary \& } \\ \text { Reading }\end{array} & \begin{array}{l}\text { Listening \& } \\ \text { Writing }\end{array} & \begin{array}{l}\text { Pragmatics \& } \\ \text { Grammar }\end{array}\end{array}$

Speaking

\begin{tabular}{|clllllll|}
\hline Group & Explicit & Count & 55 & 0 & 0 & 11 & 66 \\
\cline { 2 - 7 } & $\%$ & $83.3 \%$ & $0 \%$ & $0 \%$ & $16.7 \%$ & $100.0 \%$ \\
\cline { 2 - 7 } & Implicit & Count & 49 & 0 & 0 & 17 & 66 \\
\cline { 2 - 7 } & $\%$ & $74.2 \%$ & $0 \%$ & $0 \%$ & $25.8 \%$ & $100.0 \%$ \\
\hline \multirow{2}{*}{ Total } & Count & 104 & 0 & 0 & 28 & 132 \\
& $\%$ & $78.8 \%$ & $0 \%$ & $0 \%$ & $21.2 \%$ & $100.0 \%$ \\
\hline
\end{tabular}

\subsubsection{Necessity of Pragmatic Features of Speech Acts}


Item 22 of the students' questionnaire targeted if learning pragmatic features of the specific speech acts in English class was necessary. The results, as displayed in Table 32 indicated that the EFL learners believed that explicit learning of pragmatic features of the specific speech acts was more necessary (Mean $=3.85)$ than the implicit one (Mean =3.74). The percentages also supported these conclusions. A higher percentage of respondents $(84.8 \%$ vs. $74.2 \%)$ believed that explicit learning of pragmatic features of the specific speech acts was "very necessary" than the implicit one. The results of independentsamples $t$-test $(t=1.51, p=.133)$; however, indicated that the differences were not statistically significant.

Table 32

Descriptive Statistics; Necessity of Learning Pragmatic Features of Speech Acts by Groups

\begin{tabular}{|c|c|c|c|c|c|c|c|c|}
\hline & & \multirow[t]{2}{*}{$\mathrm{N}$} & \multicolumn{2}{|c|}{$\begin{array}{l}\text { Fairly } \\
\text { Necessary }\end{array}$} & \multicolumn{2}{|c|}{$\begin{array}{l}\text { Very } \\
\text { Necessary }\end{array}$} & \multirow[t]{2}{*}{ Mean } & \multirow[t]{2}{*}{$\begin{array}{l}\text { Std. } \\
\text { Deviation }\end{array}$} \\
\hline & & & Freq. & $\%$ & Freq. & $\%$ & & \\
\hline \multirow{2}{*}{$\begin{array}{l}\text { Is learning pragmatic } \\
\text { features of the specific } \\
\text { speech acts in English } \\
\text { class necessary? }\end{array}$} & Explicit & 66 & 10 & 15.2 & 56 & 84.8 & 3.85 & .361 \\
\hline & Implicit & 66 & 17 & 25.8 & 49 & 74.2 & 3.74 & .441 \\
\hline
\end{tabular}

\subsubsection{Suitability of Movies in Learning Pragmatic Features of Speech Acts}

Item 23 of the students' questionnaire targeted if movies were appropriate tools for learning pragmatics. The results, as displayed in Table 33 indicated that the EFL learners believed that movies were more appropriate in explicit classes (Mean $=3.85$ ) than the implicit one (Mean $=3.75)$. The percentages also supported these conclusions. A higher percentage of respondents ( $84.8 \% \mathrm{vs.} 74.2 \%$ ) believed that movies were more appropriate in explicit classes. The results of independent-samples $t$-test $(t=1.35, p=.177)$; however, indicated that the differences were not statistically significant.

Table 33

Descriptive Statistics; Suitability of Movies in Learning Pragmatics by Groups

\begin{tabular}{|c|c|c|c|c|c|c|c|c|}
\hline & & \multirow[t]{2}{*}{$N$} & \multicolumn{2}{|c|}{$\begin{array}{l}\text { Fairly } \\
\text { Necessary }\end{array}$} & \multicolumn{2}{|c|}{$\begin{array}{l}\text { Very } \\
\text { Necessary }\end{array}$} & \multirow[t]{2}{*}{ Mean } & \multirow[t]{2}{*}{$\begin{array}{l}\text { Std. } \\
\text { Deviation }\end{array}$} \\
\hline & & & Freq. & $\%$ & Freq. & $\%$ & & \\
\hline \multirow{2}{*}{$\begin{array}{l}\text { Is the use of movies } \\
\text { appropriate in learning } \\
\text { pragmatics? }\end{array}$} & Explicit & 66 & 10 & 15.2 & 56 & 84.8 & 3.85 & .361 \\
\hline & Implicit & 66 & 16 & 24.2 & 49 & 74.2 & 3.75 & .434 \\
\hline
\end{tabular}




\section{Exploring Second Research Question}

What are teachers' perceptions regarding explicit versus implicit speech acts?

A questionnaire with 24 items were distributed among six university teachers. The questionnaire included three sections; demographic information (5 items), perceptions towards teaching and learning pragmatics (13 items) and methods and techniques used in classes (6 items).

The results of the demographic section of the questionnaire indicated that all six participants were female, one of them had a teaching experience less than five years, another one between 6 to 10 years, two had teaching experiences between 10 to 15 years, and other two had taught more than 15 years. Two of the teachers had M.A., and the rest were Ph.D. holders. None of them studied overseas and all of them received knowledge on pragmatics during their studies. Table 34 summarizes the information discussed above.

Table 34

Demographic Information of Teachers

\begin{tabular}{|lllll|}
\hline Gender & Male & \multicolumn{2}{l|}{ Female } & \\
& 0 & 6 & & \\
\hline Teaching & $<5$ & 6 to 10 & 11 to 15 & $>15$ \\
Experience & 1 & 1 & 2 & 2 \\
\hline Degree & B.A. & M.A. & Ph.D. & \\
\cline { 2 - 5 } & 0 & 2 & 4 & \\
Studies & No & Yes & & \\
Overseas & 6 & 0 & & \\
Received & No & Yes & \\
Pragmatics & 0 & 6 & \\
\cline { 2 - 5 } & & & & \\
\end{tabular}

Table 35 displays the frequencies and percentages for the EFL teachers' perceptions towards teaching pragmatics. Based on these results it can be concluded that;

1: Regarding the first question as "I believe learning English means learning grammar, vocabulary, and pronunciation" the respondents were divided into two groups; $50 \%$ agreed with the idea, while another $50 \%$ strongly disagreed.

2: On second question as "I think that linguistic knowledge is as important as the knowledge of how to use the language", all participants agreed or strongly agreed with it. 
3: Answering the third question as "I often correct the mistakes my students make when they use inappropriate words although the sentences are grammatically correct", $66.7 \%$ of teachers agreed and another $33.3 \%$ were neutral.

4: When answering the fourth question as "I don't think I know how to provide students with cultural knowledge and appropriate language use" majority of the teachers; i.e. 83.3\% disagreed and strongly disagreed and only $16.7 \%$ agreed with this idea.

5: Regarding the fifth question as 'I think raising students' awareness of getting information on culture and appropriate language use is more useful than teaching specific pragmatic knowledge" majority of the teachers (66.7\%) agreed or strongly agreed, while 33.3\% disagreed with this idea.

6: On the sixth question as "I want my students to speak English like native speakers" $66.7 \%$ were neutral and another $33.3 \%$ disagreed. 
Frequencies and Percentages of Teachers' Perceptions towards Teaching Pragmatics Choice

Total

$\begin{aligned} & \text { Strongly } \\ & \text { Disagree }\end{aligned}$
Disagree Neutral Agree $\begin{aligned} & \text { Strongly } \\ & \text { Agree }\end{aligned}$

\begin{tabular}{|c|c|c|c|c|c|c|c|}
\hline \multirow{2}{*}{$\begin{array}{l}\text { I believe learning } \\
\text { English means } \\
\text { learning grammar, } \\
\text { vocabulary, and } \\
\text { pronunciation }\end{array}$} & Count & 3 & 0 & 0 & 3 & 0 & 6 \\
\hline & $\%$ & $50.0 \%$ & $0.0 \%$ & $0.0 \%$ & $50.0 \%$ & $0.0 \%$ & $100.0 \%$ \\
\hline \multirow{2}{*}{$\begin{array}{l}\text { I think that linguistic } \\
\text { knowledge is as } \\
\text { important as the } \\
\text { knowledge of how to } \\
\text { use the language }\end{array}$} & Count & 0 & 0 & 0 & 4 & 2 & 6 \\
\hline & $\%$ & $0.0 \%$ & $0.0 \%$ & $0.0 \%$ & $66.7 \%$ & $33.3 \%$ & $100.0 \%$ \\
\hline \multirow{2}{*}{$\begin{array}{l}\text { I often correct the } \\
\text { mistakes my } \\
\text { students make when } \\
\text { they use } \\
\text { inappropriate words } \\
\text { although the } \\
\text { sentences are } \\
\text { grammatically }\end{array}$} & Count & 0 & 0 & 2 & 4 & 0 & 6 \\
\hline & $\%$ & $0.0 \%$ & $0.0 \%$ & $33.3 \%$ & $66.7 \%$ & $0.0 \%$ & $100.0 \%$ \\
\hline \multirow{2}{*}{$\begin{array}{l}\text { I don't think I know } \\
\text { how to provide } \\
\text { students with } \\
\text { cultural knowledge } \\
\text { and appropriate } \\
\text { language use }\end{array}$} & Count & 3 & 2 & 0 & 1 & 0 & 6 \\
\hline & $\%$ & $50.0 \%$ & $33.3 \%$ & $0.0 \%$ & $16.7 \%$ & $0.0 \%$ & $100.0 \%$ \\
\hline \multirow{2}{*}{$\begin{array}{l}\text { I think raising } \\
\text { students' awareness } \\
\text { of getting } \\
\text { information on } \\
\text { culture and } \\
\text { appropriate } \\
\text { language use is } \\
\text { more useful than }\end{array}$} & Count & 0 & 2 & 0 & 2 & 2 & 6 \\
\hline & $\%$ & $0.0 \%$ & $33.3 \%$ & $0.0 \%$ & $33.3 \%$ & $33.3 \%$ & $100.0 \%$ \\
\hline
\end{tabular}

\begin{tabular}{llllllll}
$\begin{array}{l}\text { I want my students } \\
\text { to speak English like } \\
\text { native speakers }\end{array}$ & Count & 0 & 2 & 4 & 0 & 0 & 6 \\
\cline { 2 - 8 } & $\%$ & $0.0 \%$ & $33.3 \%$ & $66.7 \%$ & $0.0 \%$ & $0.0 \%$ & $100.0 \%$ \\
$\begin{array}{l}\text { I think teaching } \\
\begin{array}{l}\text { English } \\
\text { communicatively is }\end{array}\end{array}$ & Count & 3 & 3 & 0 & 0 & 0 & 6 \\
$\begin{array}{l}\text { not as important as } \\
\text { teaching } \\
\text { grammatical points }\end{array}$ & & $50.0 \%$ & $50.0 \%$ & $0.0 \%$ & $0.0 \%$ & $0.0 \%$ & $100.0 \%$ \\
$\begin{array}{l}\text { and vocabulary } \\
\text { items }\end{array}$ & & & & & & & \\
\end{tabular}

I believe teachers

Count 0

1

0

4

1

6 
should teach

pragmatic

knowledge when

\begin{tabular}{lllllll}
\hline & $0.0 \%$ & $16.7 \%$ & $0.0 \%$ & $66.7 \%$ & $16.7 \%$ & $100.0 \%$
\end{tabular}

students reach a

certain level of

language proficiency

I think it is important

for learners of

English to keep their

identity and culture

Count 0

0

0

4

2

6

$\% \quad 0.0 \%$

$0.0 \%$

$0.0 \%$

$66.7 \%$

$33.3 \%$

$100.0 \%$

I think learners of

English as a second

language need to

Count 1

0

4

1

0

6

understand other

$\begin{array}{lllllll}\% & 16.7 \% & 0.0 \% & 66.7 \% & 16.7 \% & 0.0 \% & 100.0 \%\end{array}$

Englishes apart from

native English

I think native

speakers of English

need to understand

the culture of

speakers of English

as a second

language

I think my way of

learning and

teaching pragmatics

in particular and

English in general is

influenced by my

mother tongue

I think the textbooks used at the Faculty

contain adequate

pragmatic

information

Total

\begin{tabular}{lllllll} 
Count & 0 & 0 & 0 & 3 & 3 & 6 \\
\hline$\%$ & $0.0 \%$ & $0.0 \%$ & $0.0 \%$ & $50.0 \%$ & $50.0 \%$ & $100.0 \%$
\end{tabular}

Count 0

0

4

2

0

6

$\% \quad 0.0 \%$

$0.0 \%$

$66.7 \%$

$33.3 \%$

$0.0 \%$

$100.0 \%$

Total

\begin{tabular}{lllllll} 
Count & 0 & 4 & 0 & 1 & 1 & 6 \\
\hline$\%$ & $0.0 \%$ & $66.7 \%$ & $0.0 \%$ & $16.7 \%$ & $16.7 \%$ & $100.0 \%$
\end{tabular}

\begin{tabular}{lllllll} 
Count & 10 & 14 & 14 & 29 & 11 & 78 \\
\hline$\%$ & $12.8 \%$ & $17.9 \%$ & $17.9 \%$ & $37.2 \%$ & $14.1 \%$ & $100.0 \%$ \\
\hline
\end{tabular}

7: All participants; i.e. $100 \%$ disagreed or strongly disagreed with the seventh question as "I think teaching English communicatively is not as important as teaching grammatical points and vocabulary items".

8: On eighth question as "I believe teachers should teach pragmatic knowledge when students reach a certain level of language proficiency" majority of the EFL teachers; i.e. 83.3\% agreed or strongly agreed, while $16.7 \%$ disagreed with this idea. 
9: When answering the ninth question as "I think it is important for learners of English to keep their identity and culture" all participants (100\%) agreed or strongly agreed with this idea.

10: Regarding the then question as "I think learners of English as a second language need to understand other Englishes apart from native English" the participants were not unanimous. Majority of the teachers; i.e. $66.7 \%$ were neutral, while $16.7 \%$ strongly disagreed and another 16.7 agreed with this idea.

11: When answering the eleventh question as "I think native speakers of English need to understand the culture of speakers of English as a second language" all EFL teachers showed their agreement with this idea.

12: Majority of the respondents (66.7\%) were neutral, and 33.3\% agreed when answering the twelfth question as "I think my way of learning and teaching pragmatics in particular and English in general is influenced by my mother tongue and by other people around me", and finally,

13: Regarding the last question as "I think the textbooks used at the Faculty contain adequate pragmatic information" majority of the EFL teachers; i.e. 66.7 disagreed; whereas, 33.3\% either agreed or strongly agreed with this idea.

Table 36 to Table 41 display frequencies and percentages for the EFL teachers' answers given to the last six items related to different methods and techniques used in classes. The results indicated that;

1: Majority of the EFL teachers claimed that they taught speech acts to their students. Another $33.3 \%$ taught general pragmatic knowledge in their classes and $16.7 \%$ taught meta-language.

Table 36

Frequencies and Percentages of Types of Pragmatic Knowledge Taught

\begin{tabular}{|lll|}
\hline & Frequency & Percent \\
\hline General & 2 & 33.3 \\
\hline Speech Acts & 3 & 50.0 \\
\hline Meta-Language & 1 & 16.7 \\
\hline Total & 6 & 100.0 \\
\hline
\end{tabular}

2: Majority of the teachers (57.1\%) believed that they taught communicative skills. Another 28.6 percent believed that they taught language use and only $14.3 \%$ linguistic skills. 
Table 37

Frequencies and Percentages of Skills Taught

\begin{tabular}{|lll|}
\hline & Frequency & Percent \\
\hline Linguistic & 1 & 14.3 \\
\hline Language Use & 2 & 28.6 \\
Communicative Skills & 4 & 57.1 \\
\hline Total & $7^{2}$ & 100.0 \\
\hline
\end{tabular}

3: Majority of the teachers (42.9\%) claimed that they taught cultural knowledge and language use through implementing tasks and activities. Another $28.6 \%$ taught them explicitly, and the rest of the teachers either used textbooks (14.3\%) or employed supplementary materials (14.3\%)

Table 38

Frequencies and Percentages of How Language Use is Taught

\begin{tabular}{|lll|}
\hline & Frequency & Percent \\
\hline Textbooks & 1 & 14.3 \\
\hline Supplementary Materials & 1 & 14.3 \\
\hline $\begin{array}{l}\text { Implementing Tasks and } \\
\text { Activities }\end{array}$ & 3 & 42.9 \\
\hline Explicit Instruction & 2 & 28.6 \\
\hline Total & 7 & 100.0 \\
\hline
\end{tabular}

4: Majority of the teachers (42.9\%) claimed that they used pair work in their classes. Another $28.6 \%$ used role play and the rest (28.6\%) employed group discussion.

Table 39

Frequencies and Percentages of Types of

Tasks Used

\begin{tabular}{|lll|}
\hline & Frequency & Percent \\
\hline Role Play & 2 & 28.6 \\
\hline Pair Work & 3 & 42.9 \\
\hline Group Discussion & 2 & 28.6 \\
\hline Total & 7 & 100.0 \\
\hline
\end{tabular}


5: Majority of the teachers (66\%) claimed that, in order to teach English use, they used awareness raising activities in their classes. Another $33.3 \%$ used role play.

Table 40

Frequencies and Percentages of Methods Used to Teach

English Use

\begin{tabular}{|lll|}
\hline & Frequency & Percent \\
\hline Role Play & 2 & 33.3 \\
\hline Awareness Raising Activities & 4 & 66.7 \\
\hline Total & 6 & 100.0 \\
\hline
\end{tabular}

6: Majority of the teachers (50\%) claimed that they did not emphasis on British no American English, while 33.3\% favored American English and 16.7\% asked their students to use British English

Table 41

Frequencies and Percentages of Types of

English Used

\begin{tabular}{|lll|}
\hline & Frequency & Percent \\
\hline American & 2 & 33.3 \\
British & 1 & 16.7 \\
$\begin{array}{l}\text { No } \\
\text { Difference }\end{array}$ & 3 & 50.0 \\
\hline Total & 6 & 100.0 \\
\hline
\end{tabular}

Both findings achieved from the analysis of the data collected through teacher' and learners' questioners and the results of the present study are in line with the findings of (Alcón Soler, 2002; Schmidt, 1993), in which they shed light on the effects of explicit instruction on L2 pragmatic competence development. They indicated that with explicit instruction, the teacher provides suggestions and explanations to the class while implicit instruction makes no overt reference to the rules.

In addition, according to Abolfathiasl and Abdullah (2015), consciousness-raising activities effect on EFL learners' immediate and delayed performance of suggestions. As well, as Zinged, Nourmohammadi and Derakhshan (2014) argued, the relative effectiveness of consciousness-raising listening prompts on the development of the speech act of apology. In addition, Birjandi and Derakhshan (2014) indicated that the 
relative effectiveness of C-R video-driven prompts on the comprehension of three speech acts on Persian learners of English.

\title{
4.2. Qualitative Data Analysis
}

\section{Exploring Third Research Question}

\begin{abstract}
What are the teachers' views, and experiences about their teaching English through Form Focused Instruction (FFI) in EFL classes?
\end{abstract}

In the current study, the researcher used thematic analysis to classify themes with the data. Based on Ezzy (2002) coding is a process of "disassembling and reassembling the data" (p. 94). In this procedure, the data should be broken into small units of texts. Then, the researcher rearranges the units by naming and categorizing them to have a clear data interpretation.

In the initial coding procedure, the researcher read and re-read the transcripts to improve the general meaning and sense of interpretation. Next, the investigator labeled key phrases that revealed the perceptions of the participants. Once the data was broken into small components, the investigator could recognize the patterns easily (Ezzy, 2002). In the third step, the investigator identified recurring key phrases and grouped them together according to semantic connotation. In the fourth step, regarding each group of phrases, the investigator assigned a code that reflected a shared meaning among all of the phrases. The code was a word, a short phrase or a sentence that was extracted from the participants' responses (Creswell \& Piano Clark, 2007).

In the current research, the frequency of the occurrence of each code was offered and maintained through citation of exact quotes from the respondents.

Regarding teaching pragmatic knowledge to students, interviewees' beliefs were investigated. In this regard, all of the teachers $100 \%$ believed in teaching pragmatic knowledge in EFL classes. They highlighted that context plays a key role in teaching pragmatic knowledge and students should know how to use the language correctly in classes. Besides, $66.7 \%$ of the teachers considered pragmatic knowledge as an integral part of one's communicative competence.

Concerning request strategies that teachers primarily teach in their classes, $50 \%$ of them considered direct instruction of strategy for beginners. Additionally, $50 \%$ of teachers highlighted indirect teaching of strategy to intermediate and advanced level students.

According to the interviewees' beliefs, majority of interviewees $66.7 \%$ believed in suggestory strategy for teaching "request construction" in their classes.

Additionally, concerning the difficulties or challenges when teaching students non-conventionally indirect strategies of request, $84 \%$ faced challenges while teaching elementary students. 
Concerning the number of the apology strategies teachers provided in their classes, $50 \%$ of the interviewee mentioned that they apply five apology strategies such as understanding, verbal avoidance, explanation, offer of repair and acknowledgment of responsibility, in their classes. Besides, 50\% mentioned that they use merely "statement of alternative" and "suggesting a repair" as an apology strategy in their classes.

Besides, concerning application of "explanation" or "acknowledgement of responsibility" as two factor of apology strategy, majority of interviewees $66.7 \%$ believed in acknowledgement of responsibility strategy and minority of them $33.3 \%$ highlighted explanation strategy as an effective factor in their language classes.

Further, regarding the application of repair strategy for teaching apology in English classes, majority of teachers $84 \%$ specified use of this type of strategy specifically in their speaking classes.

In addition, concerning the order of teaching invitation strategy "Genuine or ostensible" and the challenges teachers face while teaching these invitation strategy, the findings showed that all of the teachers, $100 \%$ favored teaching "Genuine" strategy primarily and teaching "Ostensible" one as a secondary alternative. Besides, all of them highlighted that they didn't face any challenges concerning teaching invitation strategy of speech act in English classes.

In the current study, the researcher asked two experinced instuctors in Islamic Azad University of Iran, North branch, (inter-coders) to identify the codes of qualititive data regarding interview transcripts. The kappa measure of agreement was computed in order to probe the reliability of the two raters who rated the participants' interviews. The results (Kappa $=.586, \mathrm{p}=.002)$ indicated significant agreement between the raters.

Table 43

Kappa Measure of Agreement for Interview

\begin{tabular}{|c|c|c|c|c|c|}
\hline & & Value & $\begin{array}{l}\text { Asymptotic Standard } \\
\text { Error }\end{array}$ & Approximate & $\begin{array}{l}\text { Approximate } \\
\text { Significance }\end{array}$ \\
\hline $\begin{array}{l}\text { Measure of } \\
\text { Agreement }\end{array}$ & Kappa & .586 & .219 & 3.095 & .002 \\
\hline $\mathrm{N}$ of Valid Cases & & 6 & 6 & & \\
\hline
\end{tabular}

\section{Results And Discussion}

As the results of the study indicated, there was a significant difference between explicit group and implicit group on the pragmatic comprehension of the speech act of apology, request and invitation. The findings revealed that meta-pragmatic awareness-raising group was more successful than other group since socio-pragmatic and pragma-linguistic features were implicitly taught to them. Materials accompanied by C-R activities could significantly improve the perception of the intended speech acts. In this regard, the findings are in line with previous studies that have demonstrated the advantages of explicit instruction 
(Fordyce, 2013; Takahashi, 2001). Similarly, the results are consistent with the findings of two metaanalysis studies conducted by Norris and Ortega (2000) and Spada and Tomita (2010) indicating that explicit types of instruction were more effective than implicit ones.

\section{Conclusion}

The findings have contributed to our understanding of the role of instruction on the effect of pragmatics development for intermediate-above learners of Iran. Data collected from questionnaires and semistructured interview provided rich, insightful information about students' and teachers' concerns and challenges about instructions. The collected data were analyzed quantitatively and qualitatively according to the importance of the gathered data, from most to least important.

The result of the first research question indicated that the Iranian EFL learners were more interested in explicit learning of pragmatic features of speech acts. Overall, the results from the data analysis supported the claim that explicit meta-pragmatic instruction facilitates inter-language pragmatic development. Although this study did not deal with the 'sequence' of acquiring speech act patterns and strategies, it showed that explicit meta-pragmatic instruction makes significant contributions to the learners' speech act comprehension processes.

The findings of the second research question suggest the necessity of incorporating consciousnessraising activities in the classroom. Majority of the teachers claimed that, in order to teach English use, they used awareness raising activities in their classes.

And finally, regarding the result of the third research question, all of the teachers $100 \%$ believed in teaching pragmatic knowledge in EFL classes. They highlighted that context plays a key role in teaching pragmatic knowledge and students should know how to use the language correctly in classes.

The obtained results in the present study have a proposal for syllabus designers and material writers to have a new intuition to the content of syllabi and textbooks especially for EFL contexts.

In conclusion, a replication and extension of this study is needed. Although this study has some limitations: 1) results only focused on intermediate-above learners of Iranians, and 2) only request, apology, and invitation speech act were tested in the study. Until more is known about how other levels of learners react to those variables, I suggest pragmatic instruction in the foreign language classroom at all levels.

\section{Abbreviations}

EFL: English as a Foreign language.

FFI: Focus-on-form.

OPT: Oxford placement Test, 
ESL: English as a second language,

C-R: Consciousness-raising

\section{Declarations}

\section{Acknowledgements}

We would like to appreciate the teachers and learners of the study as well as the reviewers of the paper.

\section{Authors' contributions}

The first author collected the data and involved in data analysis and discussion. The corresponding author read the manuscript and approved it. Both of them are responsible for all parts of the paper.

\section{Funding}

The study received no funding.

\section{Availability of data and materials}

Data sharing is not applicable to this study because confidentiality of the data was assured when collecting the data.

\section{Competing interests}

The authors declared no potential conflicts of interest with respect to the research, authorship, and/or publication of this article.

\section{Author details}

- Melahat Amir Jahansouz Shahi is the lecturer of Islamic Azad University, Tehran North Branch in department of English Language. She is Ph.D. student in TEFL. She has published four articles and translated five books. She, also, Compiled and translated three books.

- Neda Gharagozloo is the assistant professor of Islamic Azad University, Varamin, Pishva Branch in linguistic major.

She has participated in so many different conferences or seminars all through the world. She has published so many books. Also, she has published so many articles in scientific journals, ISI, and Scopus journals.

\section{References}


1. Abolfathiasl, H., \& Abdullah, A. N. (2015). Pragmatic consciousness-raising activities and EFL learners' speech act performance of 'making suggestions'. Journal of Language Teaching and Research, 6(2), 333-342.

2. Alcón Soler, E. (2002). Relationship between teacher-led versus learners' interaction and the development of pragmatics in the EFL classroom. International Journal of Educational Research, 37(3), 359-377.

3. Alco'n, E., \& Pitarch, J. G. (2010). The effect of instruction on learners' pragmatic awareness: A focus on refusals. International Journal of English Studies. 10(1), 65-80.

4. Alemi, M. (2012). Patterns and variations in native and non-native intelanguage pragmatic rating: Effects of intercultural identity, self-assessment, and rater training. Unpublished Ph.D. dissertation, Allameh Tabataba'i University, Tehran, Iran.

5. Al-Issa, A. (2003). Sociocultural transfer in L2 speech behaviors: Evidence and motivating factors. International Journal of Intercultural Relations, 27, 581-601.

6. Bardovi-Harlig, K., \& Hartford, B. S. (1991). Saying "no" in English: Native and nonnative rejections. In L. Bouton \& Y. Kachru (Eds.), Pragmatics and language learning (Vol. 2; pp. 41-57). Urbana, IL: University of Illinois at Urbana-Champaign.

7. Bardovi-Harlig, K. (2001). Evaluating the empirical evidence: Grounds for instruction in pragmatics. In K. R. Rose \& G. Kasper (Eds.), Pragmatics in language teaching (pp. 13-22). New York, NY: Cambridge University Press.

8. Bardovi-Harlig,K., \& Hartford, B.S. (2005). Interlanguage Pragmatics; Exploring Institutional Talk. Lawrence Erlbaum Associates, Publishers Mahwah, New Jersey.

9. Bagheri, M., \& Hamrang. A. (2013). The effect of meta pragmatic instructions on the interpretation and use of apology speech acts of English as a foreign language learner (EFL) at intermediate level. International J. Soc. Sci. \& Education, 3 (4), 964-975.

10. Birjandi, P., \& Derakhshan, A. (2014). The impact of consciousness-raising video-driven vignettes on the pragmatic development of apology, request, \& refusal. Applied Research on English Language, 3, 67-85

11. Byon, A. S. (2004). Learning linguistic politeness. Applied Language Learning, 14, 37-62.

12. Cambourne, B. (1999). Conditions for literacy learning: Turning learning theory into classroom instruction. A minicase study. The Reading Teacher, 54(4), 414-429.

13. Creswell, J. W., \& Plano Clark, V. L. (2007). Designing and conducting mixed methods research. Thousand Oaks, CA: Sage.

14. Davies, C. E. (2004). Developing awareness of crosscultural pragmatics: The case of American/ German sociable interaction. Multilingua, 23, 207-231.

15. Dole, J. A. (2000). Explicit and implicit instruction in comprehension. Reading for meaning: Fostering comprehension in the middle grades, 52-69. 
16. Domakani, M., Hashemian, M. \& Mansoori, S., (2013).Pragmatic Awareness of the Request Speech Act in English as an Additional Language: Monolinguals or Bilinguals?110 /RALS, 4 (1).

17. Dörnyei, Z. (2007). Research methods in applied linguistics. Oxford, UK: Oxford University Press.

18. Ezzy, D. (2002). Qualitative analysis: Practice and innovation. Sydney, NSW: Psychology Press.

19. Fordyce, K. (2013). The differential effects of explicit and implicit instruction on EFL learners' use of epistemic stance. Applied Linguistics, 35(1), 6-28.

20. Halenko, N., \& Jones, C. (2011). Teaching pragmatic awareness of spoken requests to Chinese EAP learners in the UK: Is explicit instruction effective? System, 39(2), 240-250.

21. Jick, T. D. (1979). Mixing qualitative and quantitative methods: Triangulation in action. Administrative Science Quarterly, 24(4), 602-611.

22. Kanagy, R. (1999). Interactional routines as a mechanism for L2 acquisition and socialization in an immersion context. Journal of Pragmatics, 31, 1467-1492.

23. Kasper, G. (2001). Classroom research on interlanguage pragmatics. In K.R. Rose \& G. Kasper (Eds.), Pragmatics in Language Teaching. Cambridge University Press, Cambridge, pp. 33-60.

24. Kasper, G., \& Schmidt, R.(1996). Developmental issues in interlanguage pragmatics. Studies in Second Language Acquisition, 18, 149-169.

25. Liddicoat, A., \& Crozet, C. (2001). Acquiring French interactional norms through instruction. In K. Rose \& G. Kasper (Eds.), Pragmatics in Language Teaching (pp. 125-144). Cambridge, England: Cambridge University Press.

26. Lyster, R. (1994). The effect of functional-analytic teaching on aspects of French immersion students' sociolinguistic competence. Applied Linguistics, 15, 263-287.

27. Martínez-Flor, A. (2004). The effect of instruction on the development of pragmatic competence in the English as a foreign language context: a study based on suggestions. Doctoral dissertation, Universitat

28. Matreyek, W. (1990). Communicating In English Examples Models, And Functions. London: Prentice Hall International.

29. Norris, J. M., \& Ortega, L. (2000). Effectiveness of L2 instruction: A research synthesis and quantitative meta-analysis. Language Learning, 50(3), 417-528.

30. Ohta, A. S. (2001). A longitudinal study of the development of expression of alignment in Japanese as a foreign language. In K. R. Rose \& G. Kasper (Eds.), Pragmatics in Language Teaching (pp. 103120). New York: Cambridge University Press. Ohta, A. S. (2005). Interlanguage pragmatics in the zone of proximal development. System, 33, 503-517.

31. Olshtain, E., \& Cohen, A.D. (1991).Teaching speech act behavior to nonnative speakers.In M. CelceMurcia (Ed.), Teaching English as a second or foreign language (pp. 154-165. Boston, MA: Heinle\&Heinle.

32. Richards, J. C. (2003). Developing tactics for listening: Student book. Oxford, UK: Oxford University Press. 
33. Rose, K.R. (2000). An exploratory cross-sectional study of interlanguage pragmatic development. Studies in Second Language Acquisition

22:27-67.

34. Rose, K. R. (2005). On the effects of instruction in second language pragmatics. System, 33(3), 385399.

35. Rose, K. R. (1997). Pragmatics in the classroom: Theoretical concerns and practical possibilities. Pragmatics and language learning, 8(2), 267-292.

36. Rose, K.R. \& C.K. Ng. (2001). Inductive and deductive teaching of compliments and compliment responses. In K.R. Rose \& G. Kasper (Eds.), Pragmatics in Language Teaching. Cambridge University Press, Cambridge, pp. 145-170

37. Rose, K.R., \& Ng Kwai-Fun, C. ( 2001). Inductive and deductive teaching of compliments and compliment responses. In K. R. Rose \& G. Kasper (Eds.), Pragmatics in language teaching (pp. 145170). Cambridge University Press.

38. Salemi, A., Rabiee, M., \& Ketabi, S. (2012). The Effects of Explicit/Implicit Instruction and Feedback on the Development of Persian EFL Learners $₫$ Pragmatic Competence in Suggestion Structures. Journal of Language Teaching and Research, 3(1), 188-199.

39. Saslow, J. M., \& Ascher, A. (2006). Top Notch: English for today's world, 1A. New York: Pearson Longman.

40. Schmidt, R. (1993). Consciousness, learning and interlanguage pragmatics.In G. Kasper \& S. BlumKulka (Eds.), Interlanguage pragmatics (pp. 21-42). New York: Oxford University Press.

41. Sedighi, F., \& Nazari, S. (2007). The impact of consciousness raising and teaching methodology factors on the use of learning strategies by male EFL learners. Journal of the Faculty of Letters and Humanities (Kerman), 21(18), 19-36.

42. Shokouhi, S. and Rezaei, A. (2015). The Importance of Teaching Pragmatics in the Classrooms (Focus on Complimenting). Journal for the Study of English Linguistics,

43. 2015 , Vol. 3, No. 1

44. Spada, N., \& Tomita, Y. (2010). Interactions between type of instruction and type of language feature: A meta-analysis. Language Learning, 60(2), 263-308.

45. Swain, M. (1998). Focus on form through conscious reflection. In C. Doughty \& J. Williams (Eds.), Focus on form in classroom second language acquisition (pp. 64-81). New York: Cambridge University Press.

46. Swain, M., \& Lapkin, S. (1995). Problems in output and the cognitive processes they generate: A step towards second language learning. Applied Linguistics, 16, 371-391.

47. Swain, M., \& Lapkin, S. (1986). Immersion French at the secondary level: "The goods" and "the bads." Contact, 2-9.

48. Takahashi, S. (2001). The role of input enhancement in developing pragmatic competence. Pragmatics in language teaching, 171-199. 
49. Tateyama, Y. (2001). Explicit and implicit teaching of pragmatics routines: Japanese sumimasen. In K. R. Rose \& G. Kasper (Eds.), Pragmatics in language teaching (pp. 200-222). England: Cambridge University Press.

50. Tajeddin, Z., \& Alemi, M. (2013). Criteria and bias in native English teachers' assessment of L2 pragmatic appropriacy: Content and FACETS analyses. The Asia Pacific Education Researcher, 23(3), 425-434. DOI 10.1007/s40299-013-0118-5

51. Thomas, J. (1983). Cross cultural pragmatic failure. Applied Linguistics, 4, 91-112.

52. Willis, D., \& Willis, J. (1996). Consciousness-raising activities. In D. Willis \& J. Willis (Eds.), Challenge and change in language teaching (pp. 63-76). Oxford, UK: Heinemann.

53. Yoon, K. (1991). Bilingual pragmatic transfer to speech acts: Bi-directional responses to a compliment. In L. Bouton \& Y. Kachru (Eds.), Pragmatics and language learning (Vol. 2; pp. 75-100). Urbana, IL: University of Illinois at Urbana-Champaign.

54. Zangoei, A., \& Derakhshan, A. (2014). Iranian EFL learners' ILP comprehension and their language learning preferences: The effect of consciousness- raising instruction. International Journal of Language Learning and Applied Linguistics World (IJLLALW), 5 (2), 211-232.

\section{Figures}

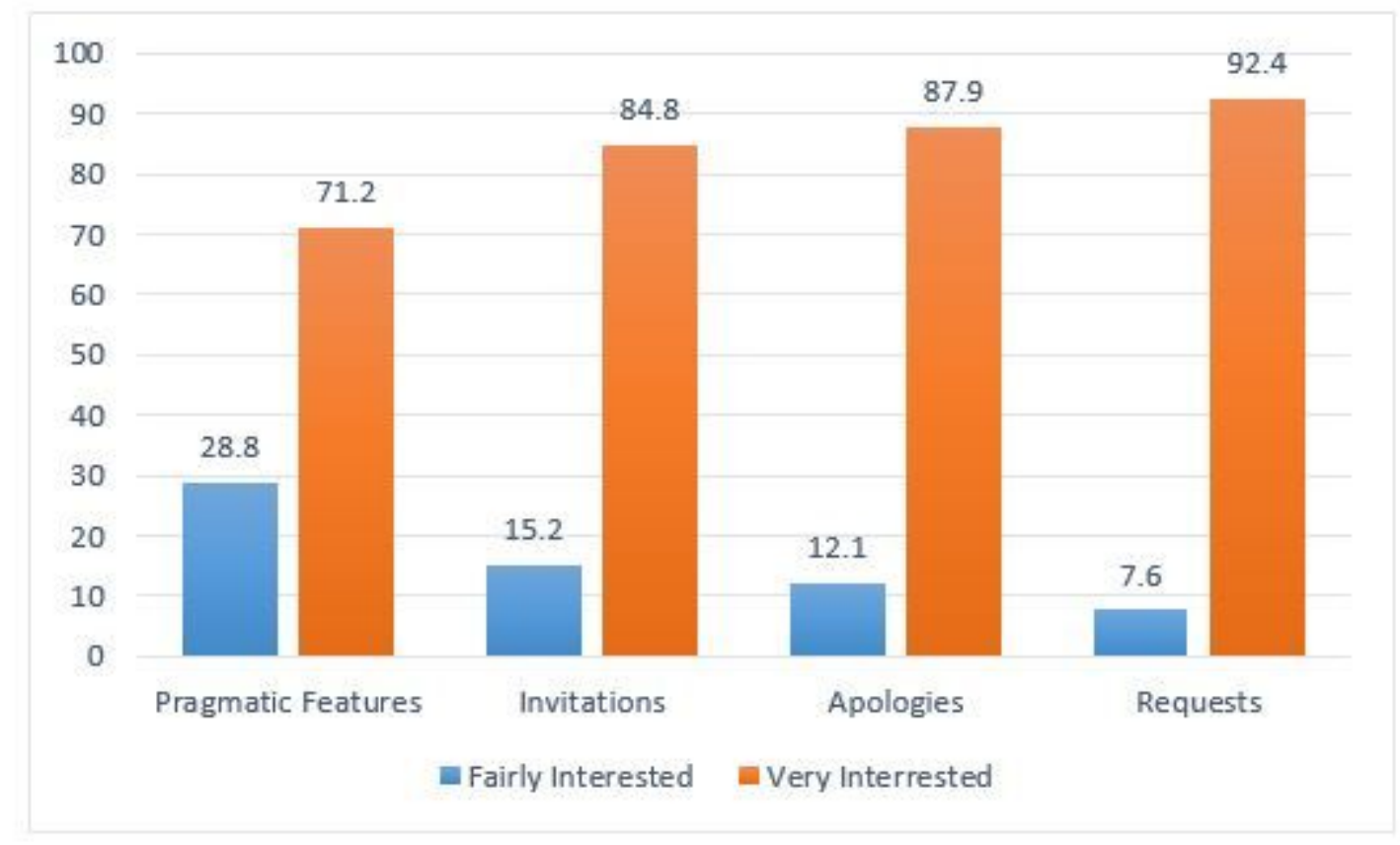

\section{Figure 1}

Percentages of interest in explicit learning of speech acts 


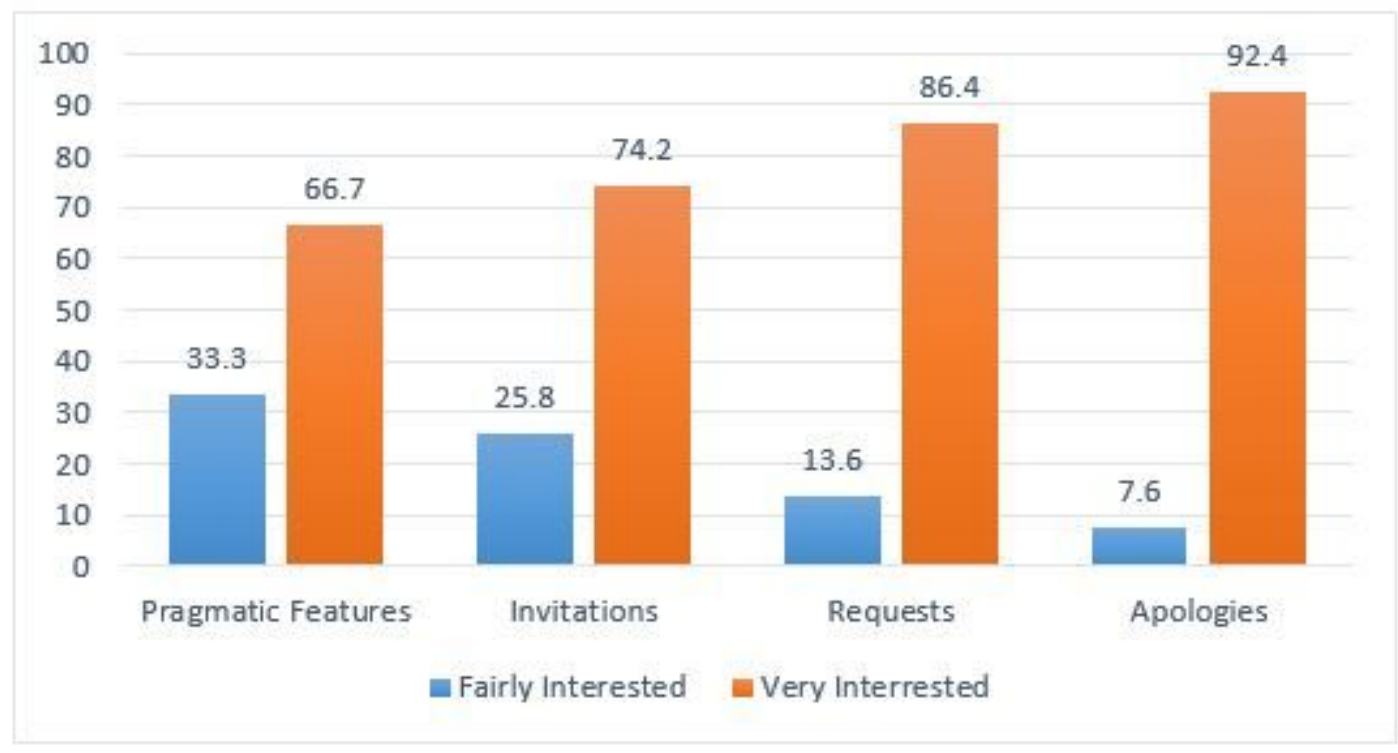

Figure 2

Percentages of interest in implicit learning of speech acts

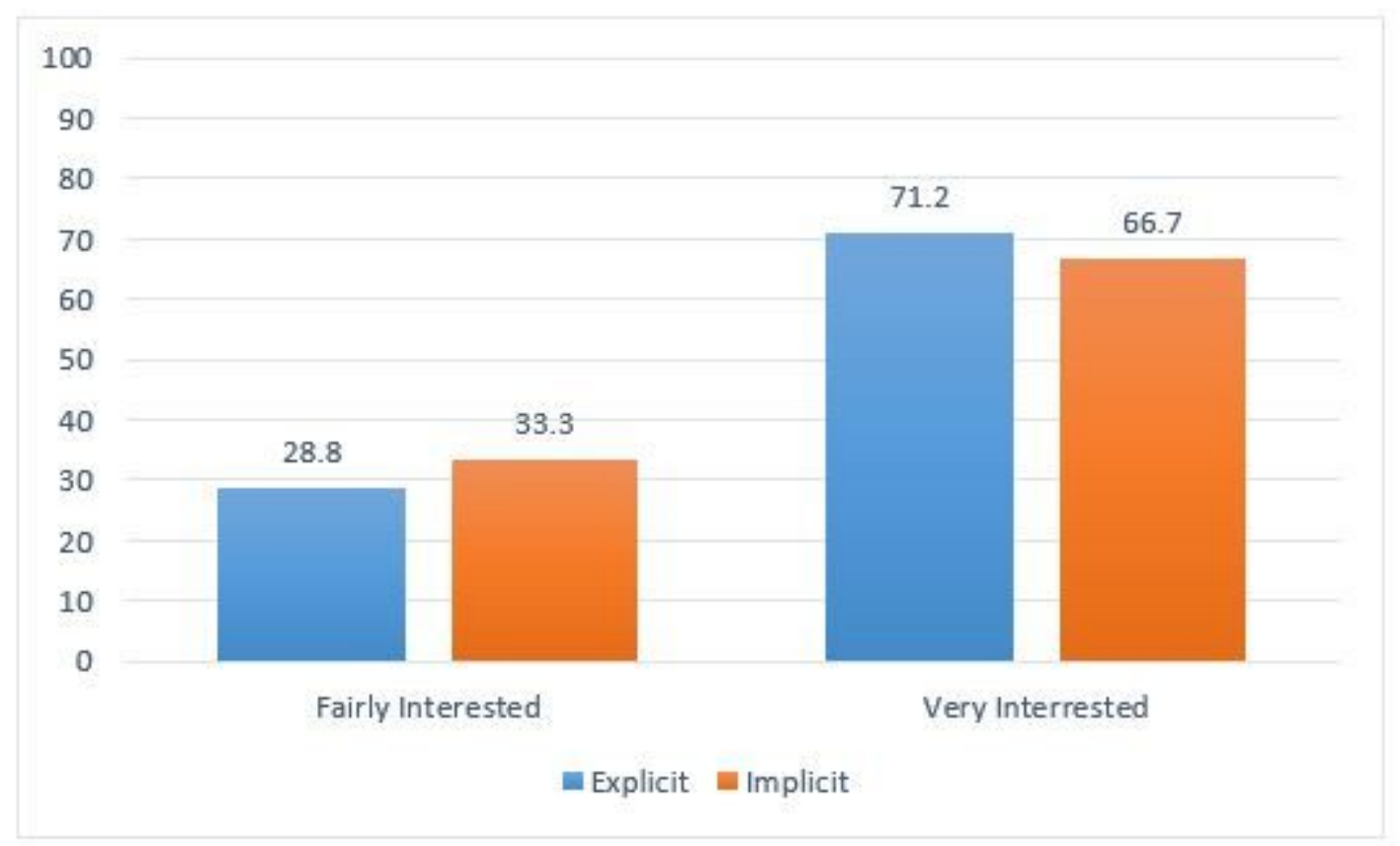

Figure 3

Percentages of interest in explicit vs. implicit learning of pragmatic features of speech acts 


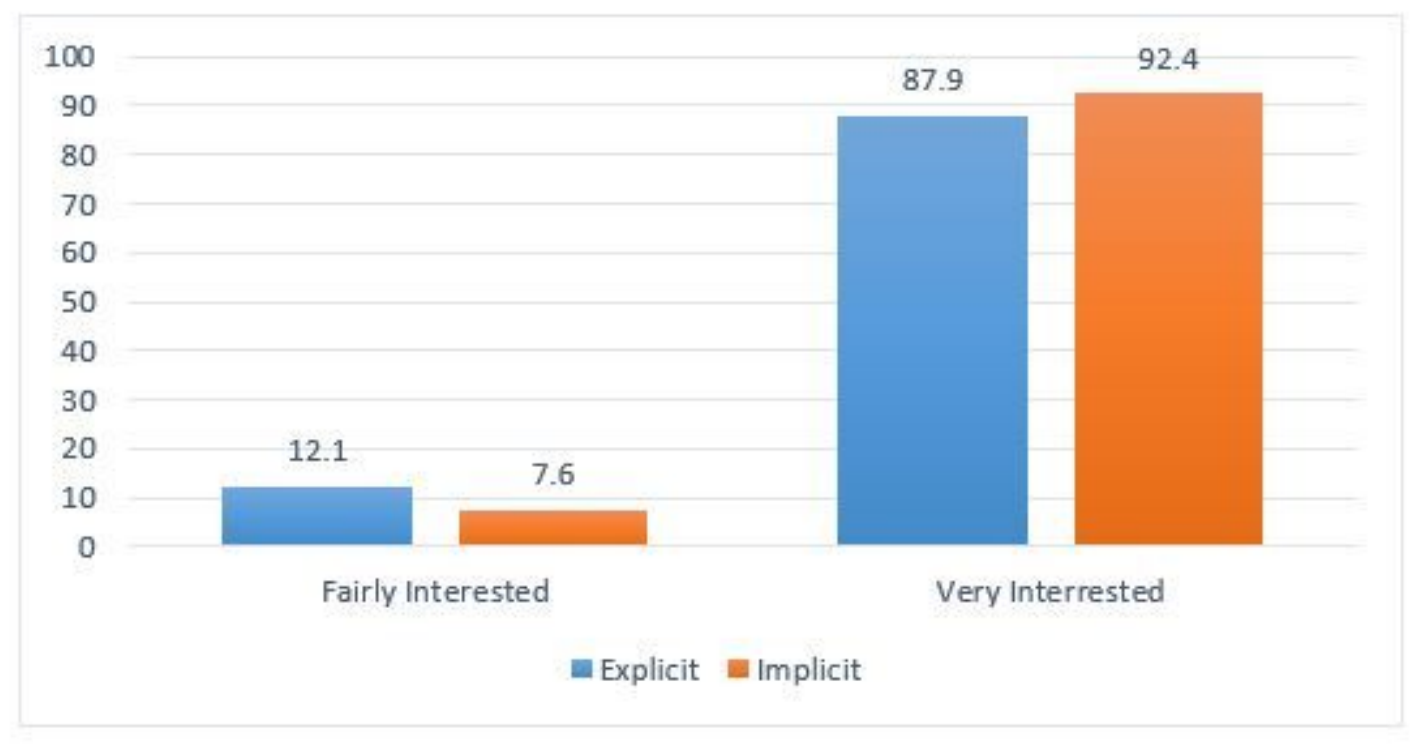

Figure 4

Percentages of interest in explicit vs. implicit learning of pragmatic features of speech acts of invitations.

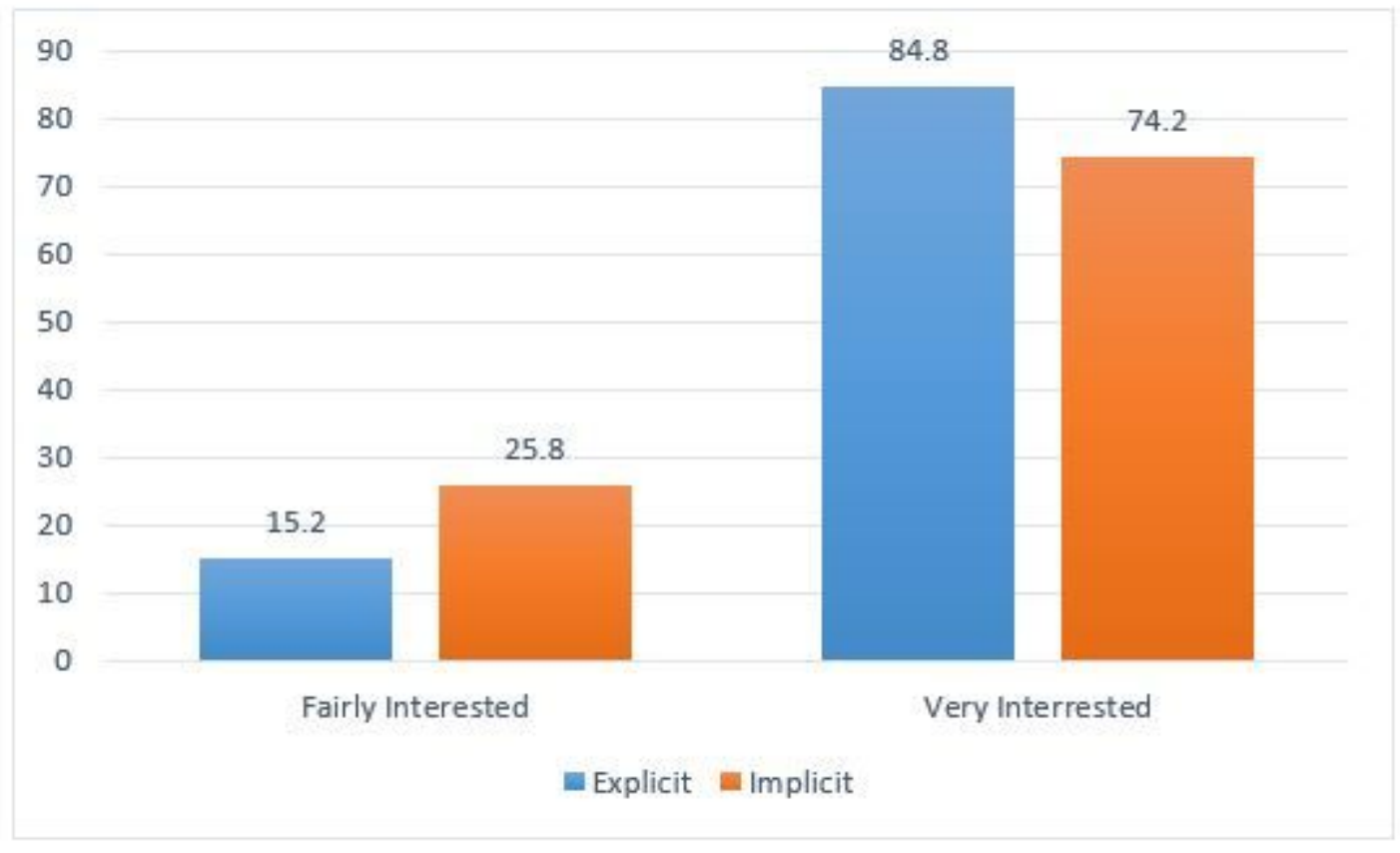

Figure 5

Percentages of interest in explicit vs. implicit learning of pragmatic features of speech acts of apologies 


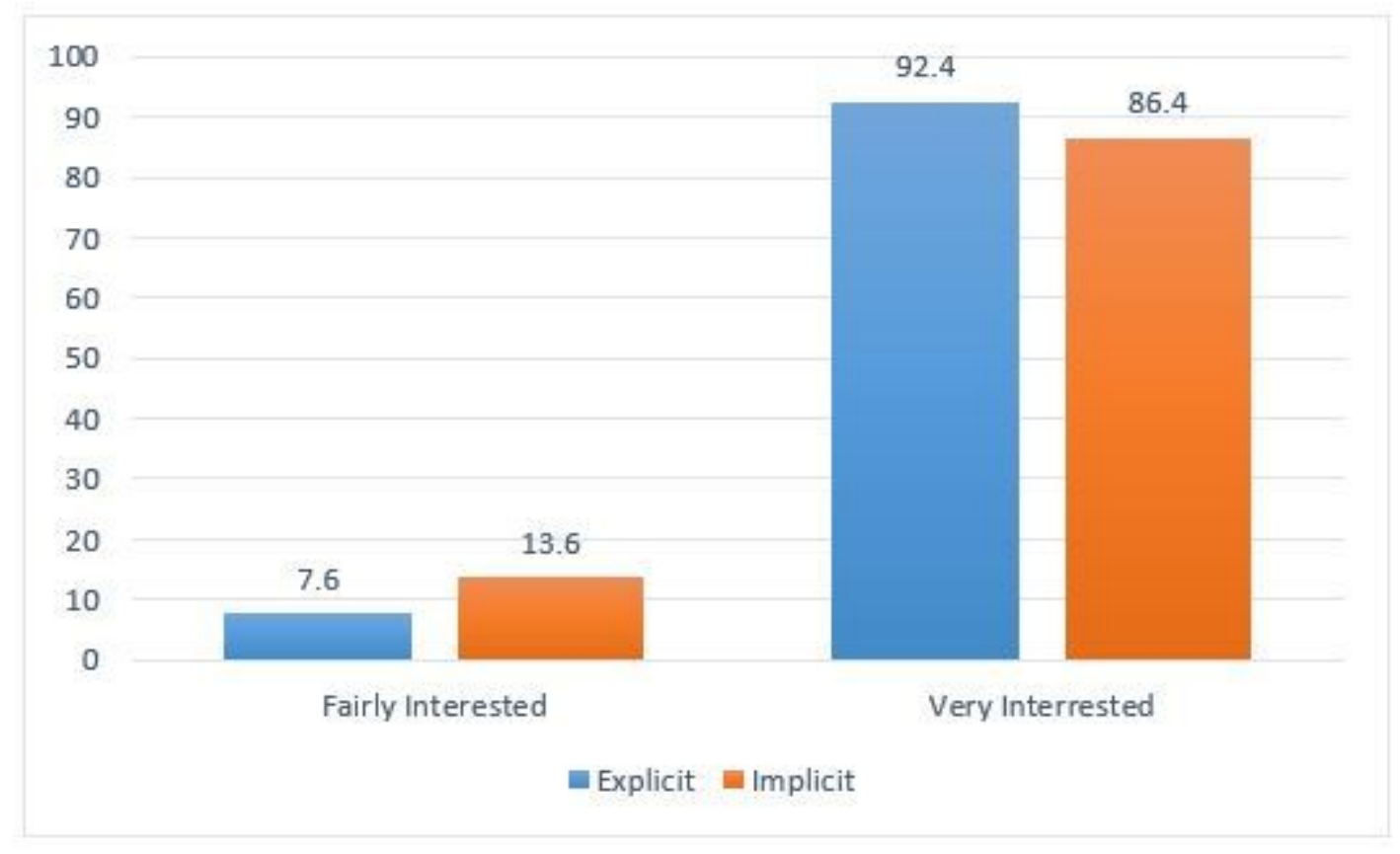

Figure 6

Percentages of interest in explicit vs. implicit learning of pragmatic features of speech acts of request

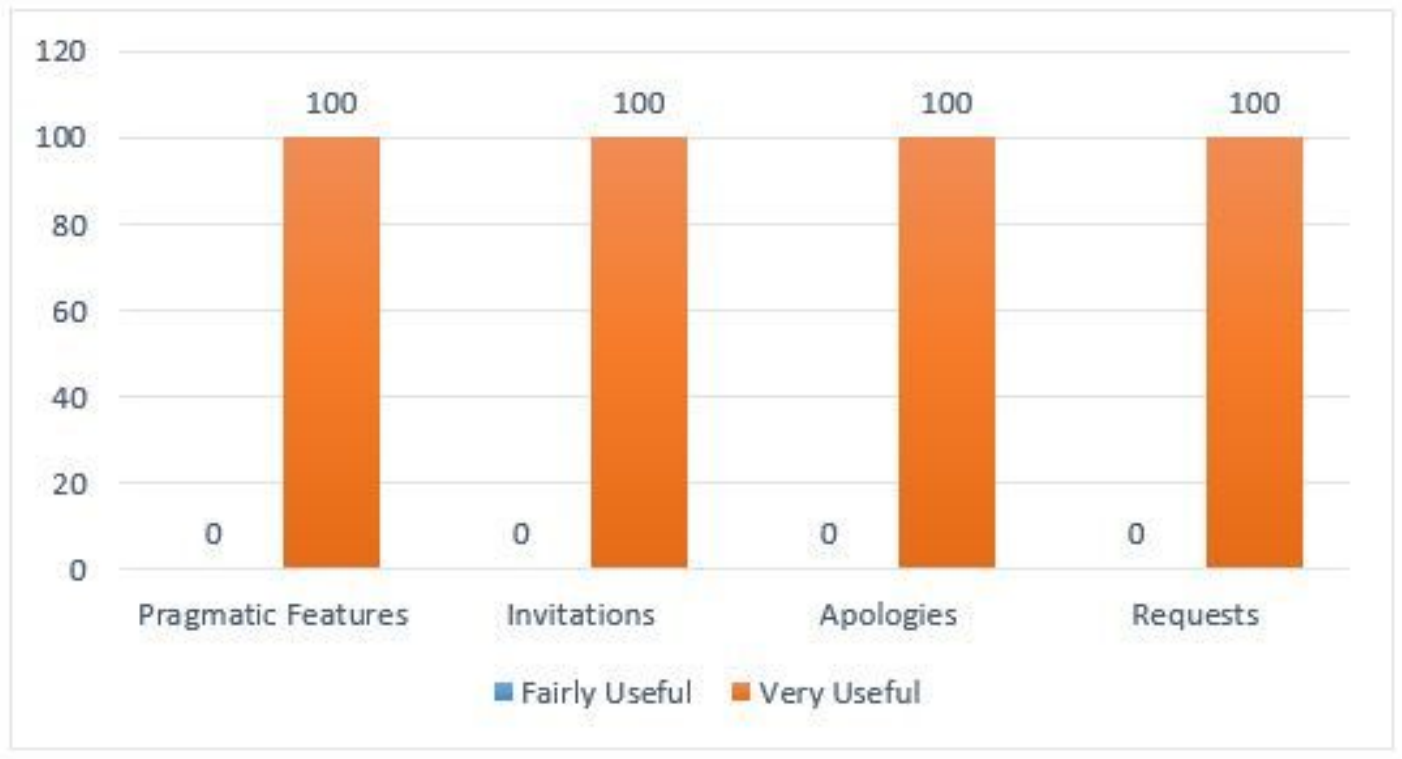

Figure 7

Percentages of usefulness of explicit learning of speech acts 


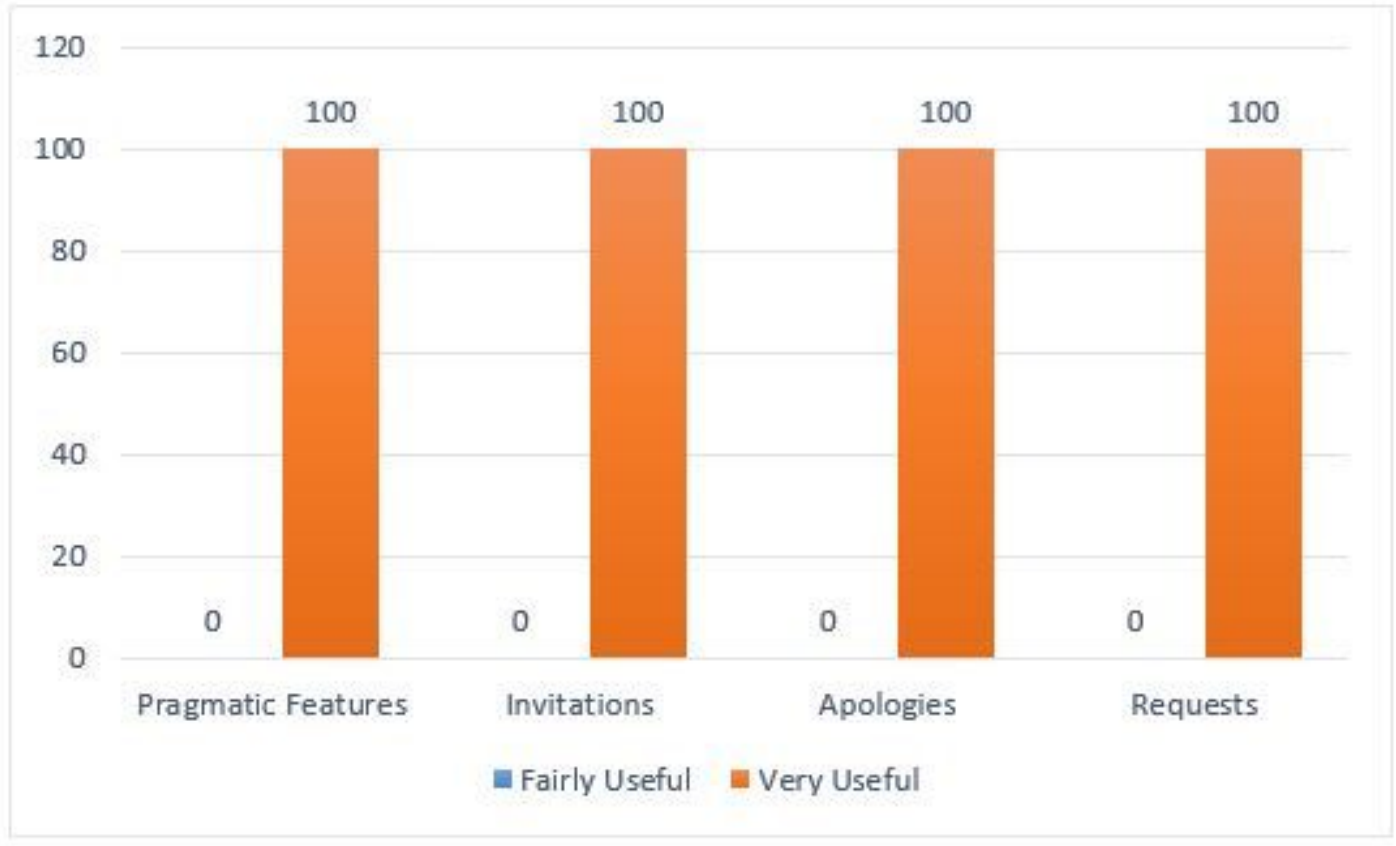

Figure 8

Percentages of usefulness of implicit learning of speech acts

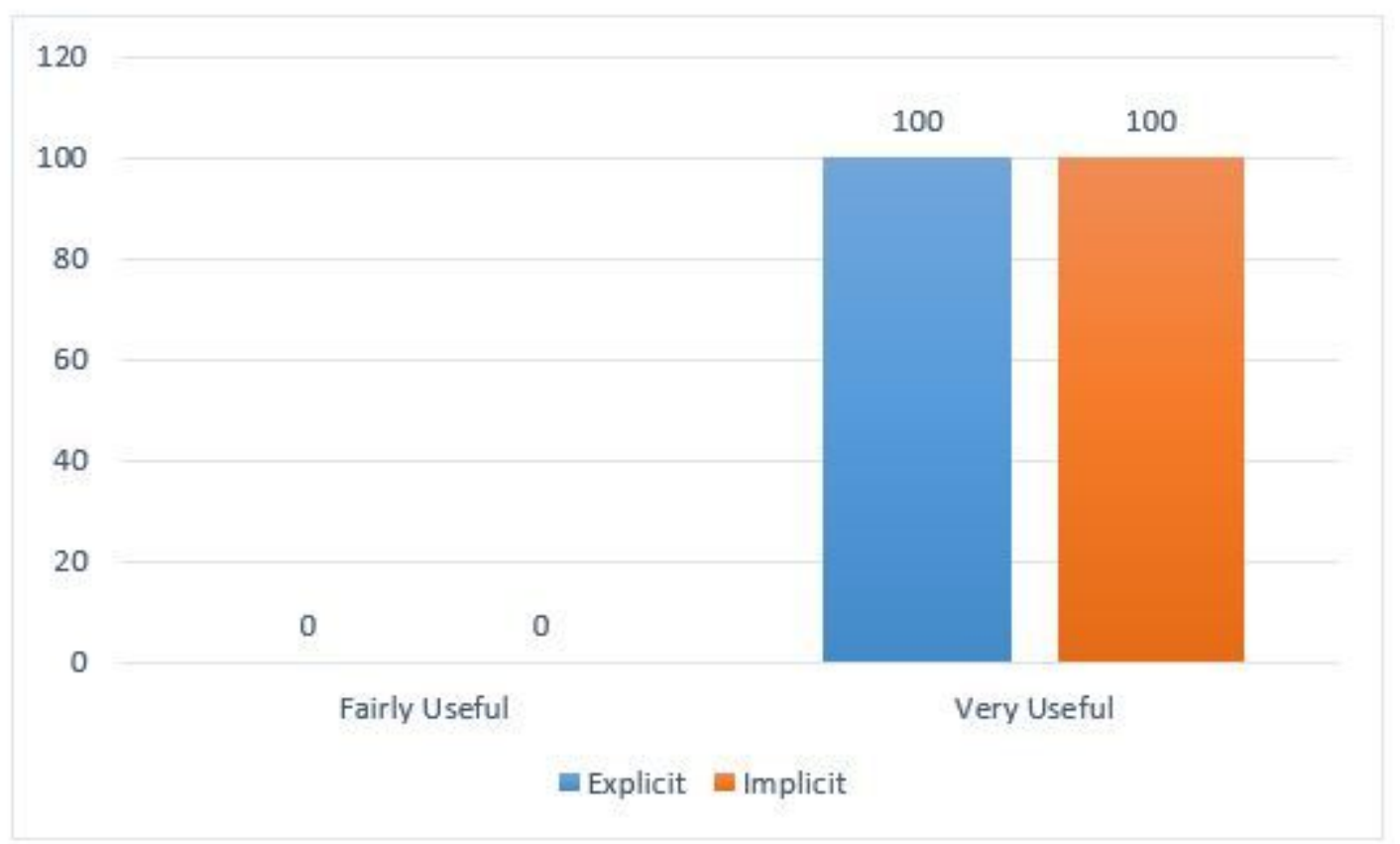

Figure 9

Percentages of usefulness of explicit vs. implicit learning of pragmatic features of speech acts 


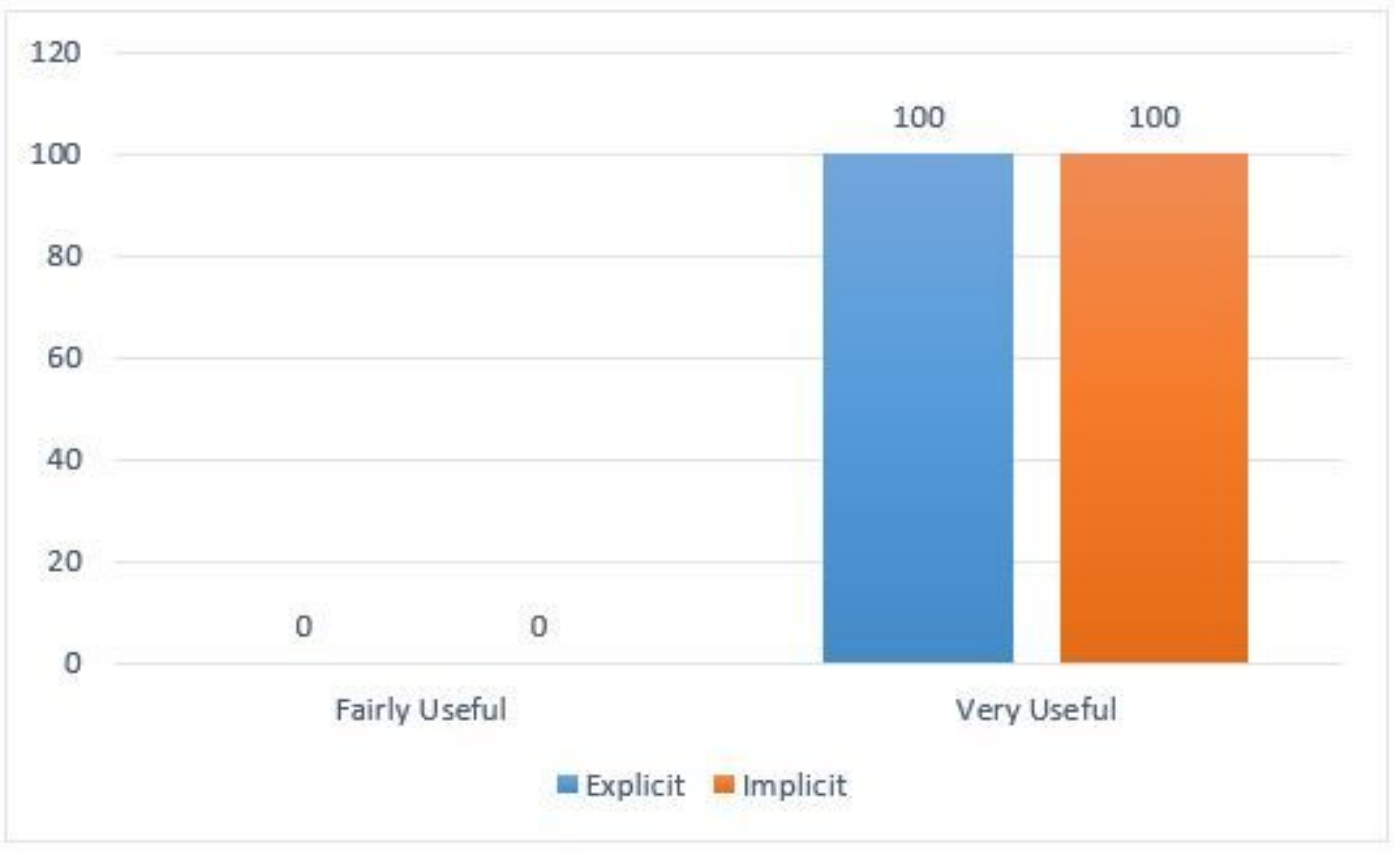

\section{Figure 10}

Percentages on usefulness of explicit vs. implicit learning of pragmatic features of speech acts of invitations

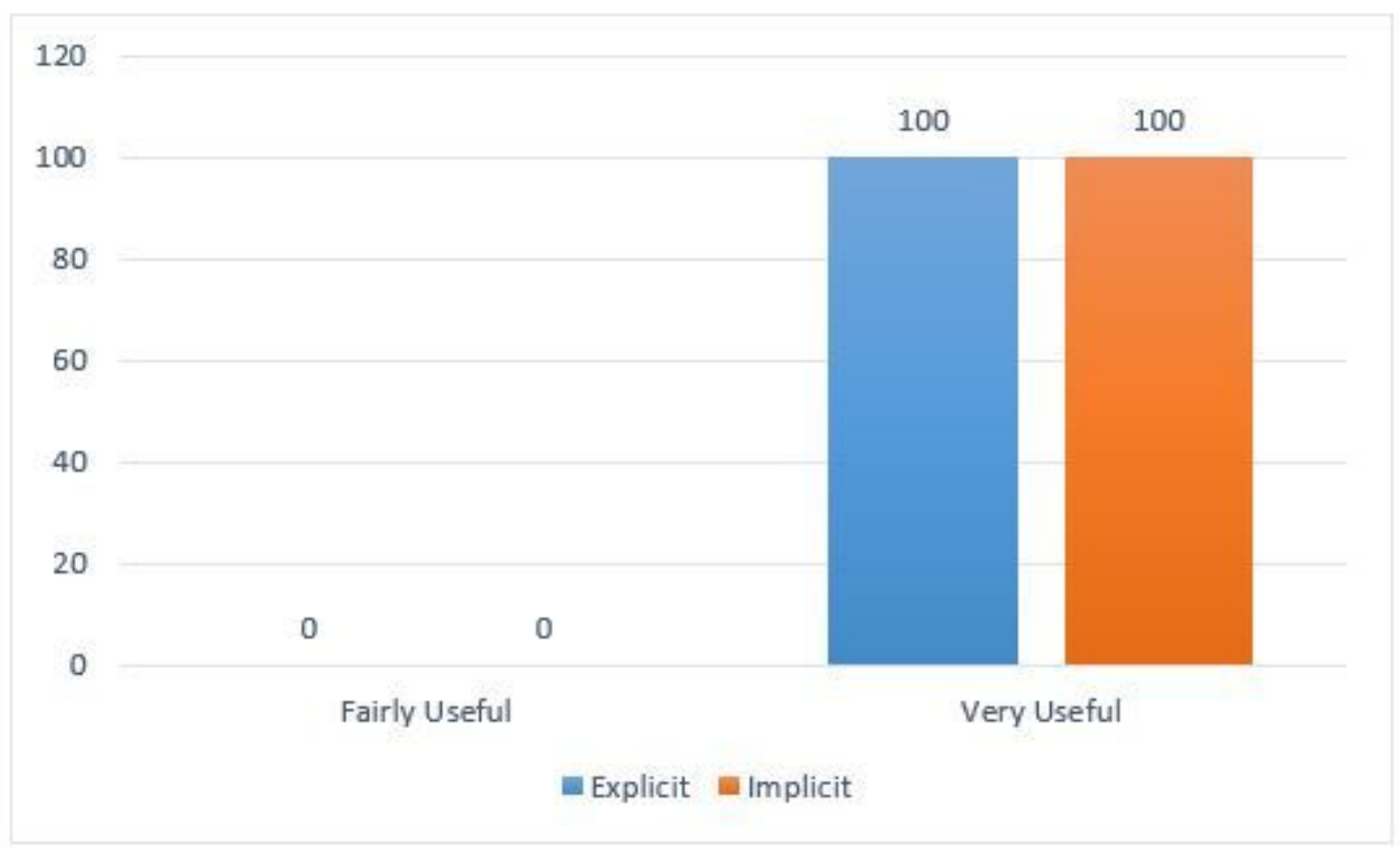

\section{Figure 11}

Percentages on usefulness of explicit vs. implicit learning of pragmatic features of speech acts of apologies 


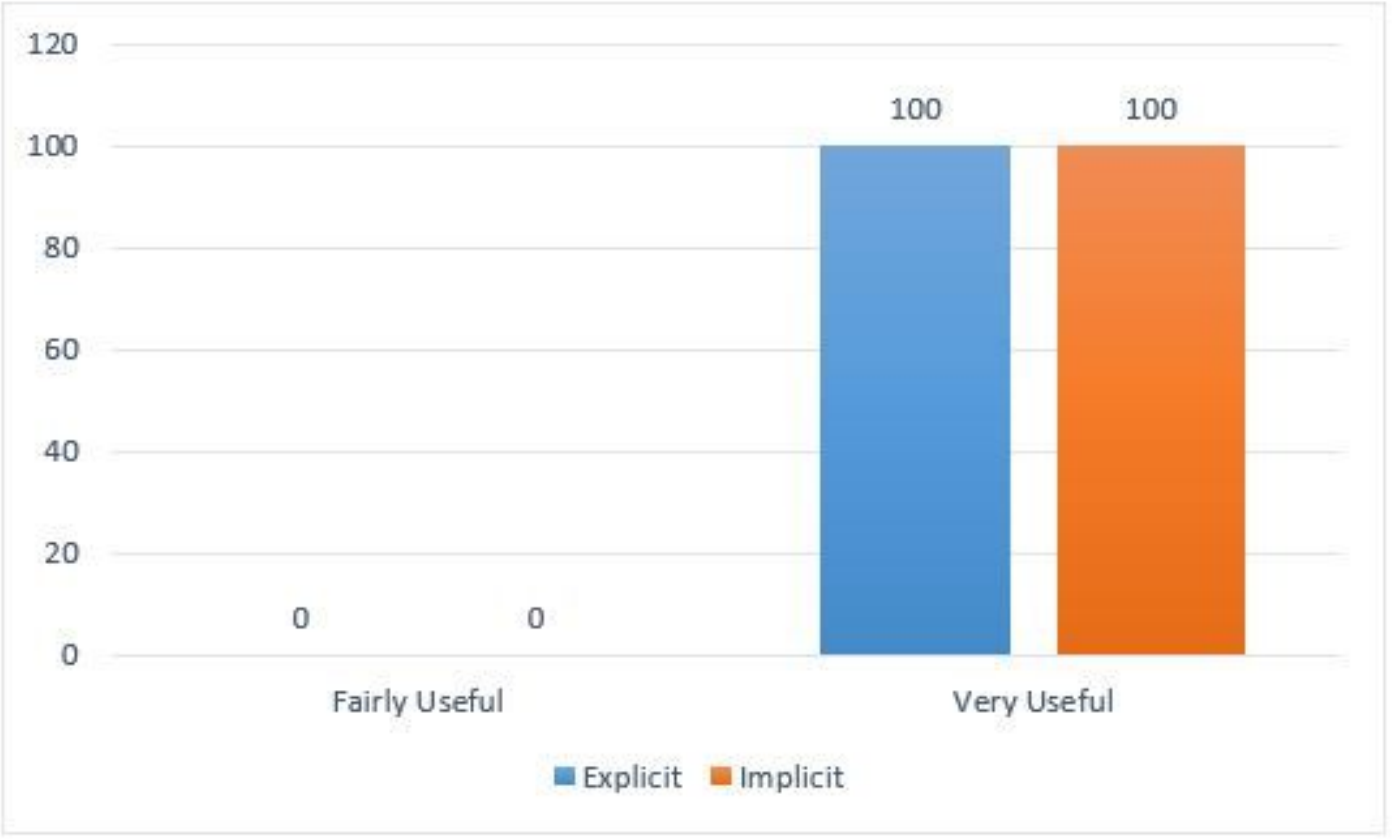

\section{Figure 12}

Percentages on usefulness of explicit vs. implicit learning of pragmatic features of speech acts of request

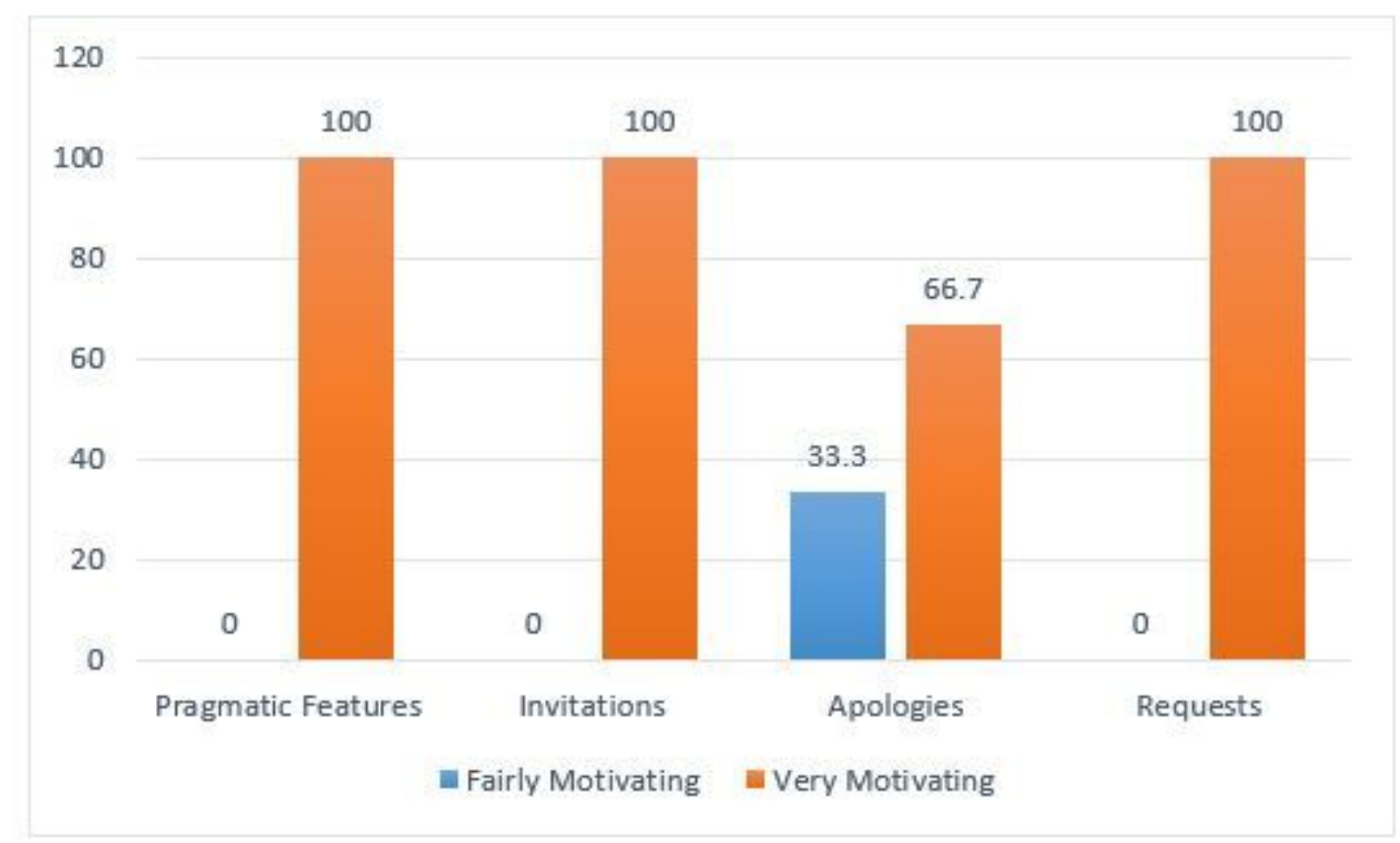

Figure 13

Percentages of motivation in explicit learning of speech acts 


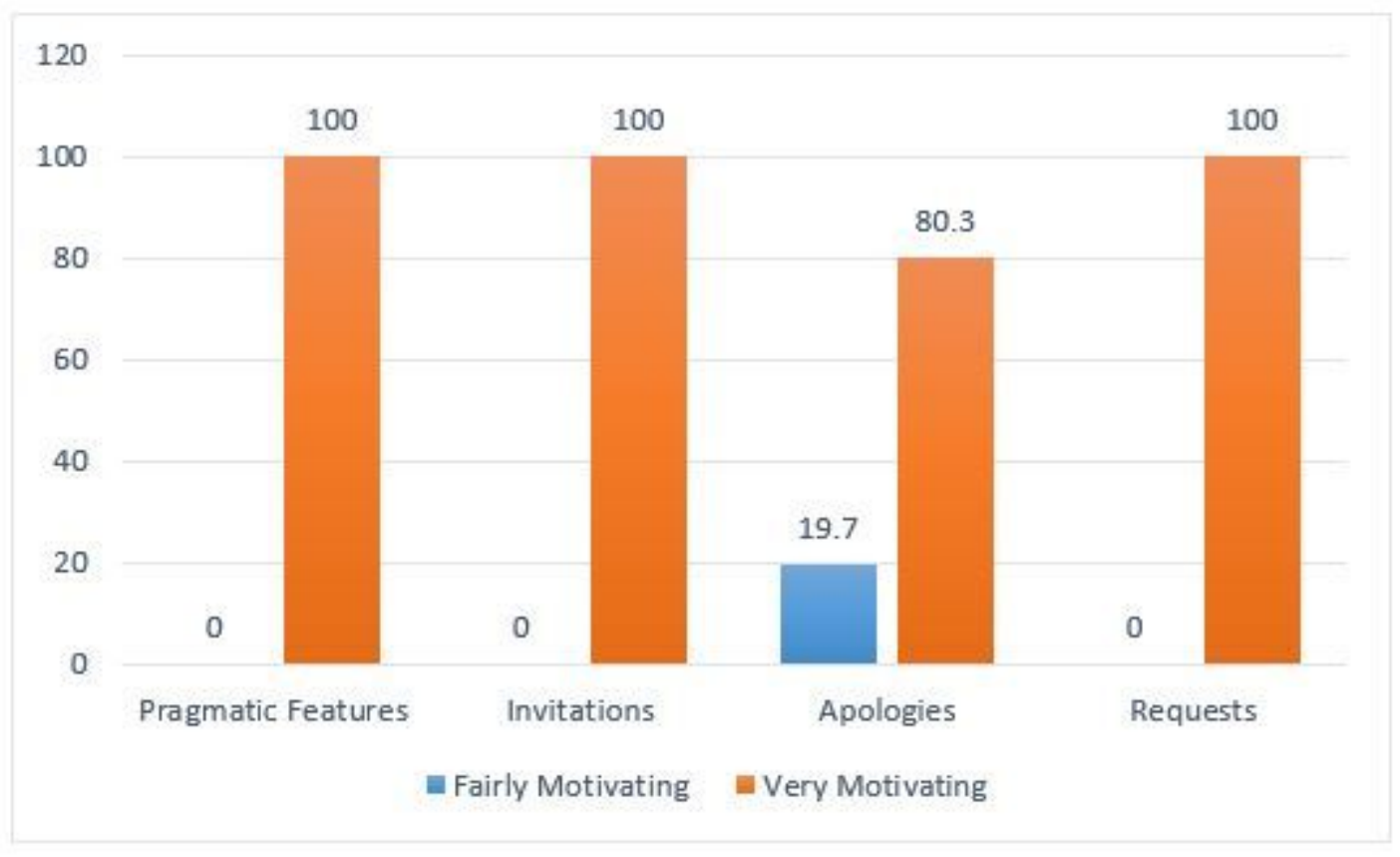

Figure 14

Percentages of motivation in implicit learning of speech acts

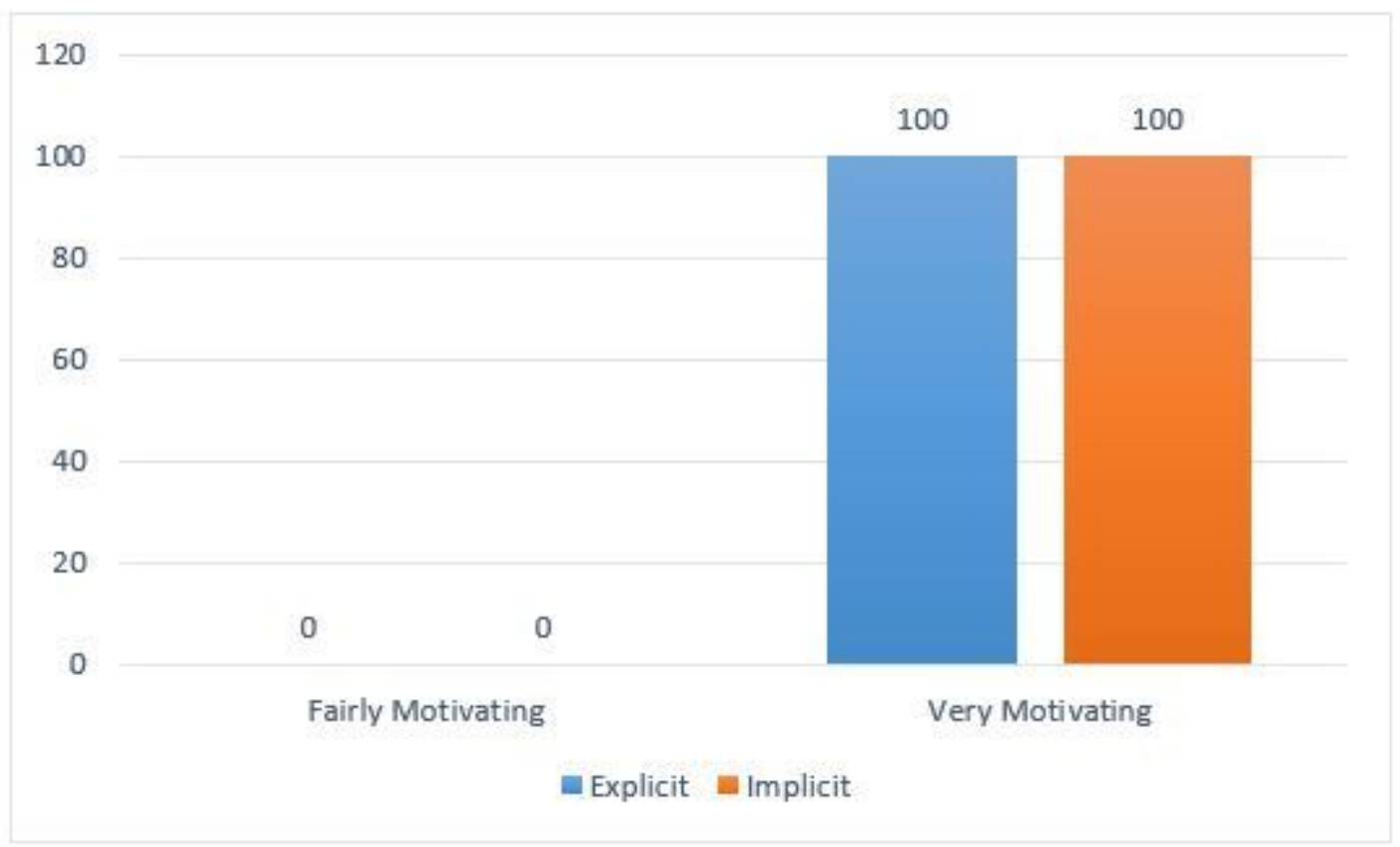

Figure 15

Percentages of motivation in explicit vs. implicit learning of pragmatic features of speech acts 


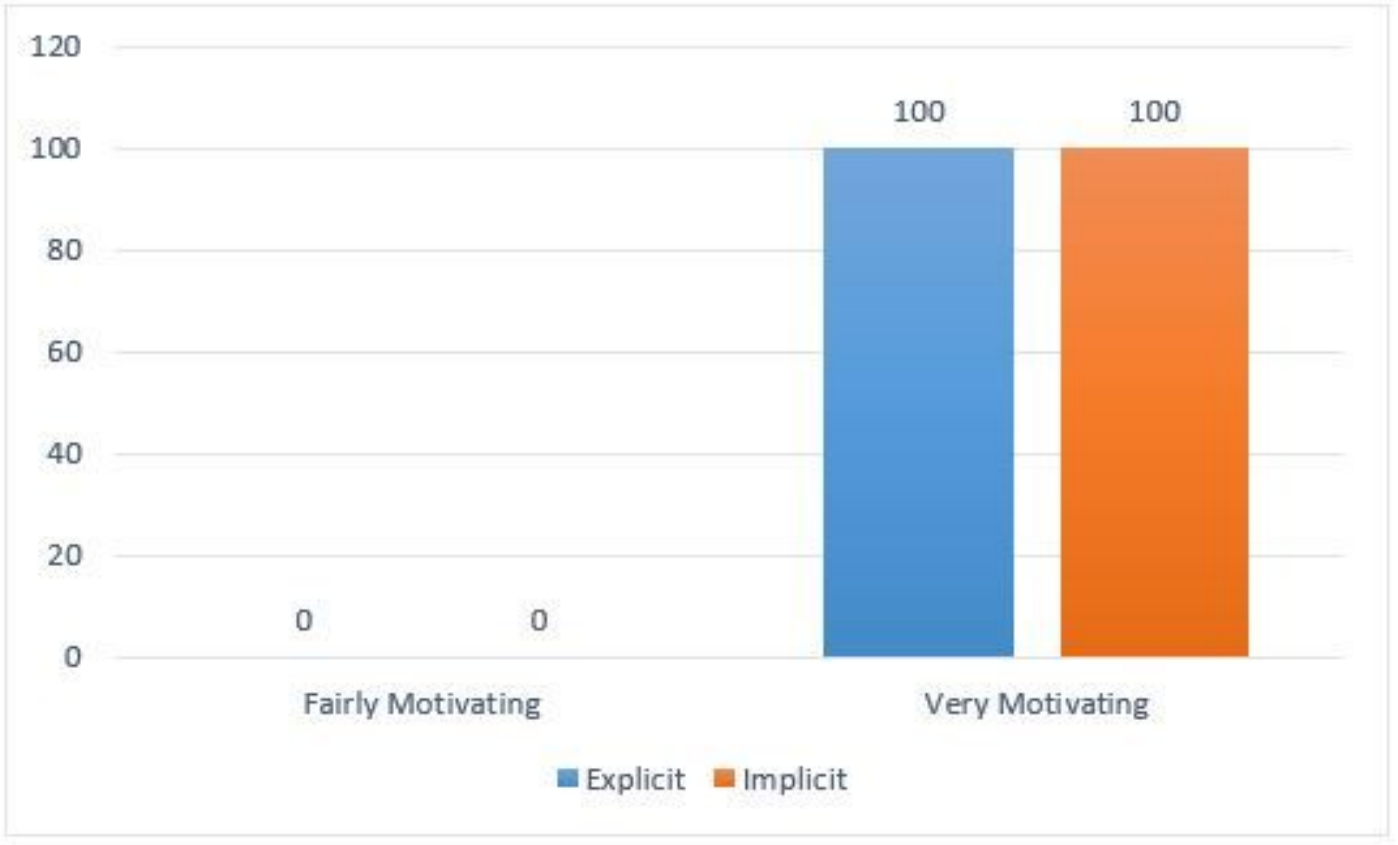

\section{Figure 16}

Percentages on motivation in explicit vs. implicit learning of pragmatic features of speech acts of invitations

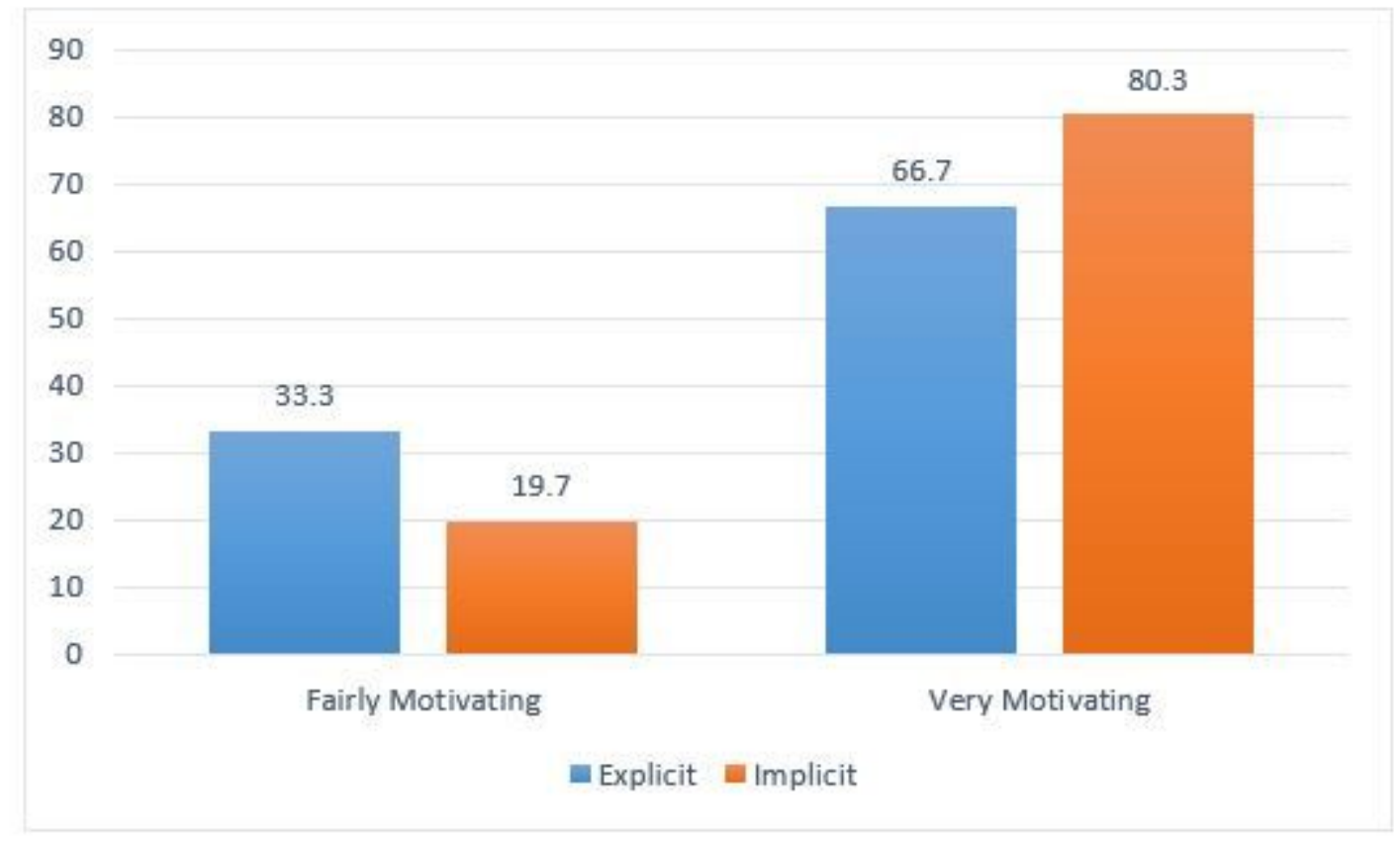

Figure 17

Percentages on motivation in explicit vs. implicit learning of pragmatic features of speech acts of apologies 


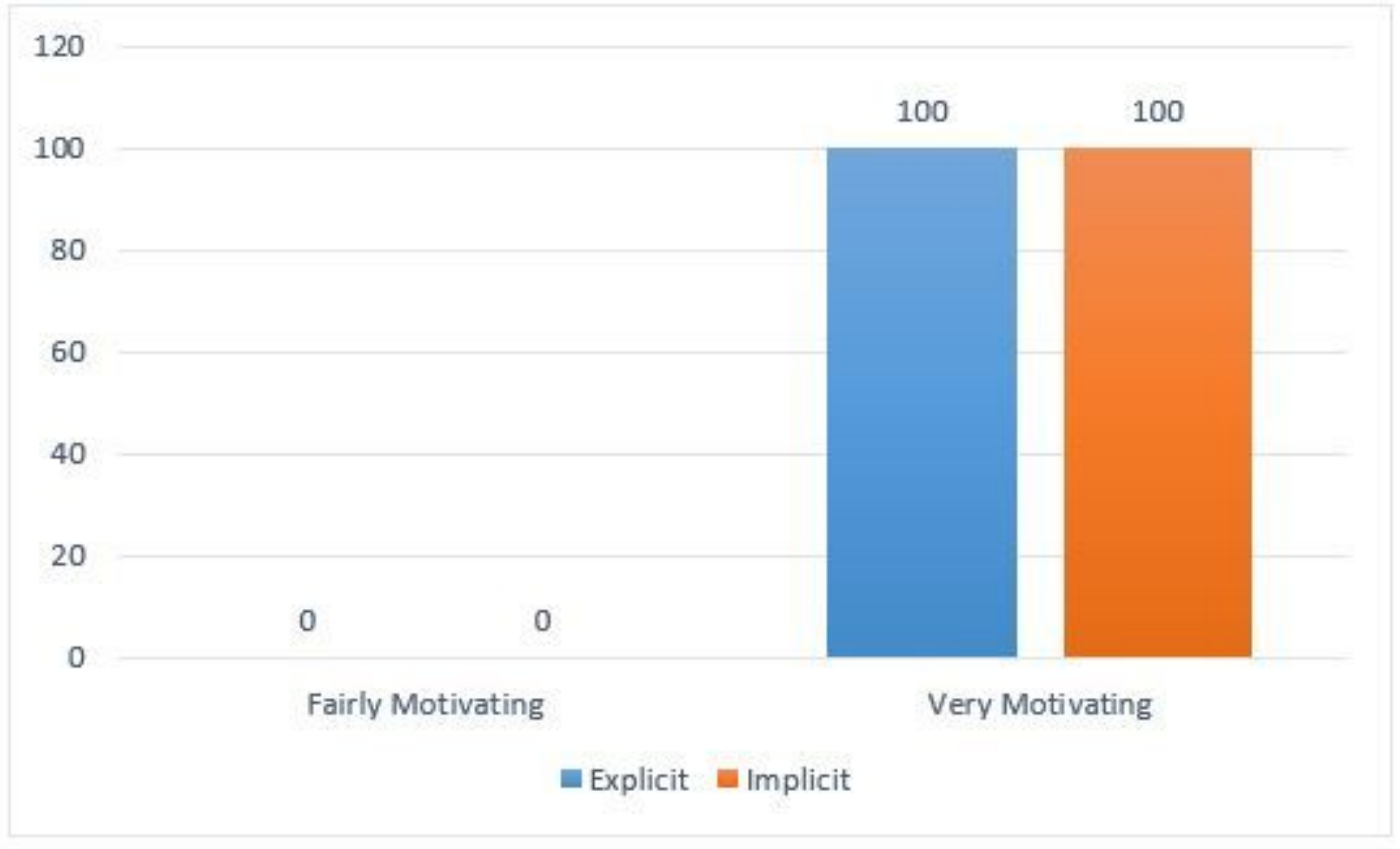

\section{Figure 18}

Percentages on motivation in explicit vs. implicit learning of pragmatic features of speech acts of request

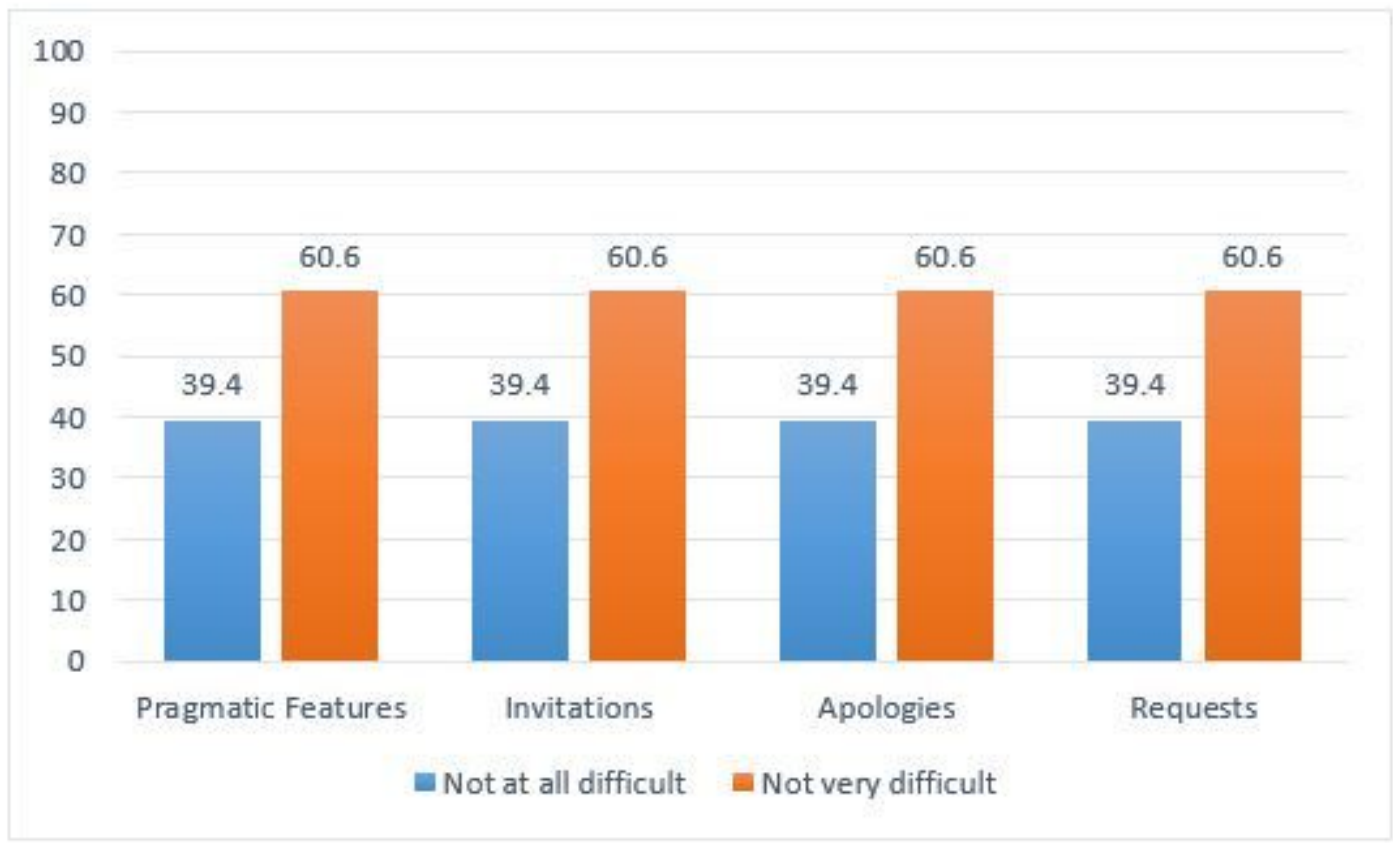

Figure 19

Percentages of difficulty of explicit learning of speech acts 


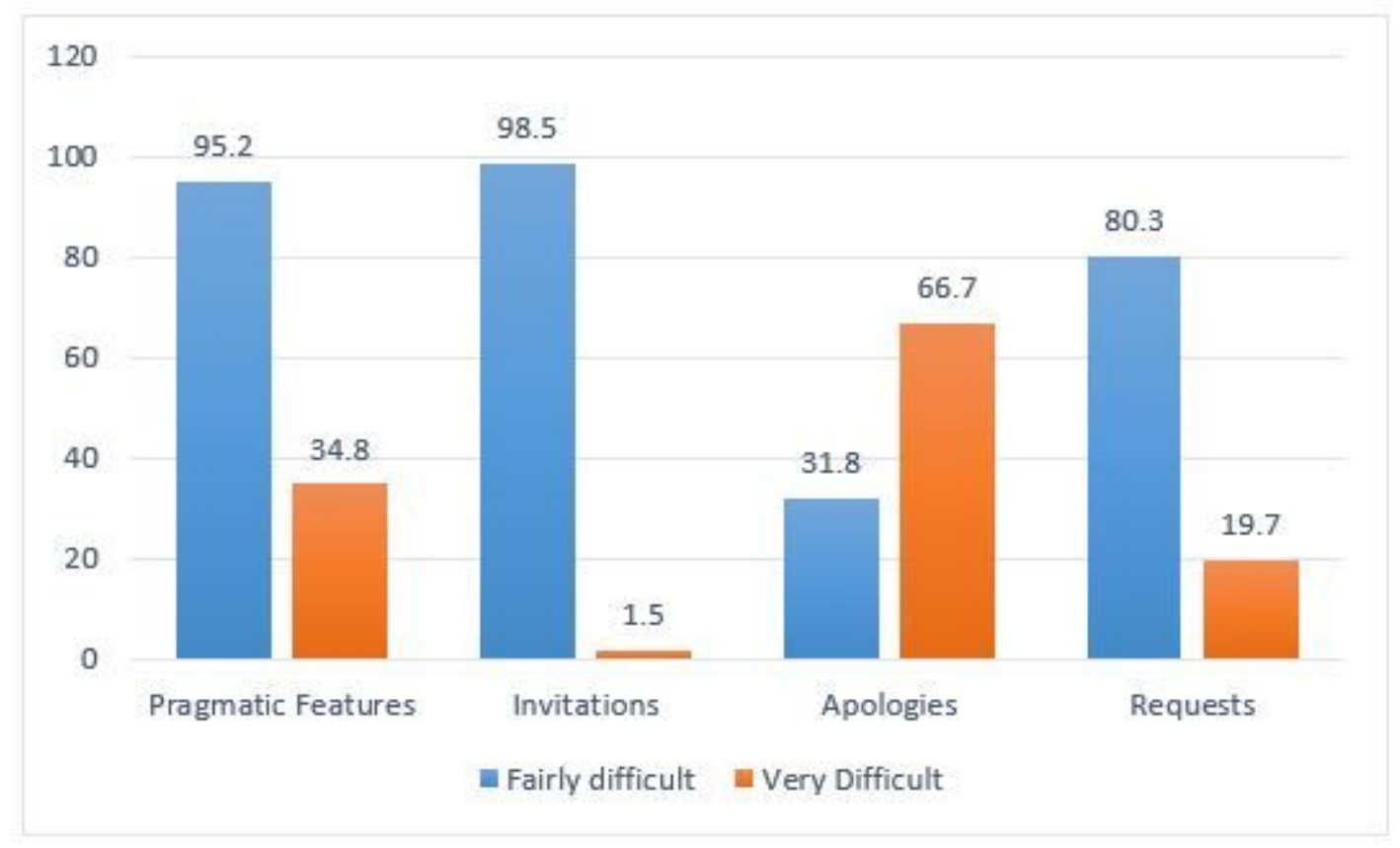

\section{Figure 20}

Percentages of difficulty of implicit learning of speech acts

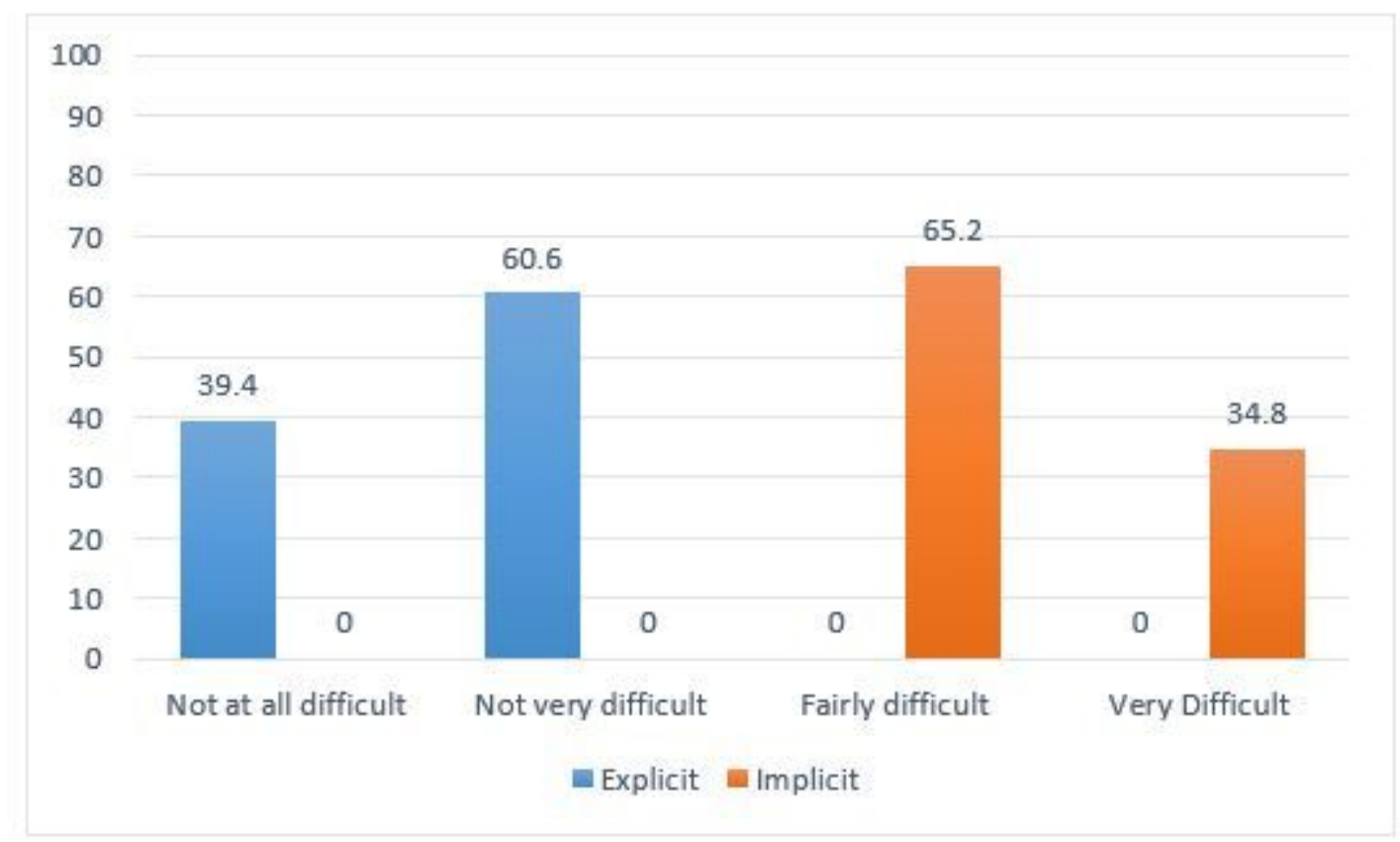

Figure 21

Percentages of difficulty of explicit vs. implicit learning of pragmatic features of speech acts 


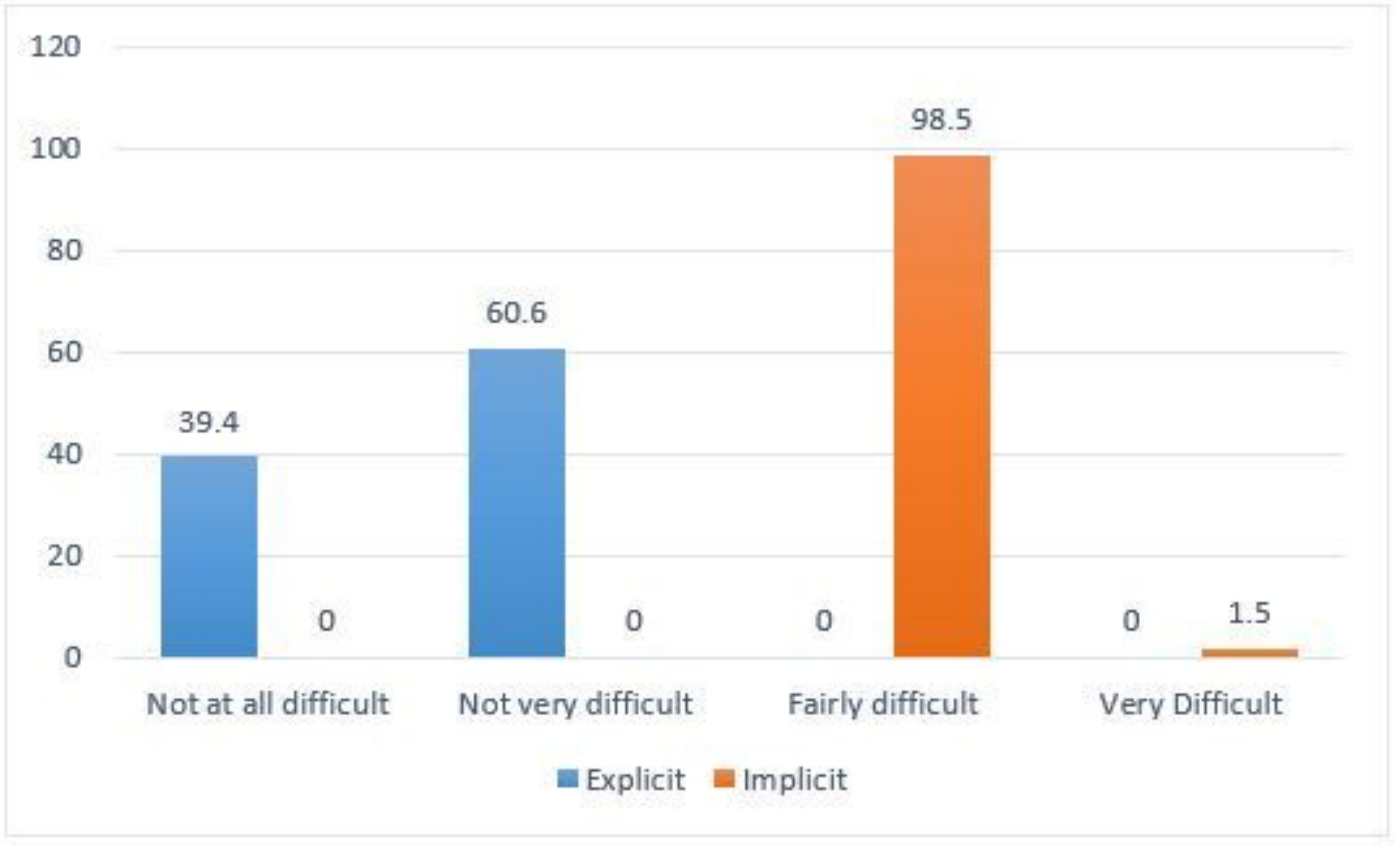

\section{Figure 22}

Percentages on difficulty of explicit vs. implicit learning of pragmatic features of speech acts of invitations

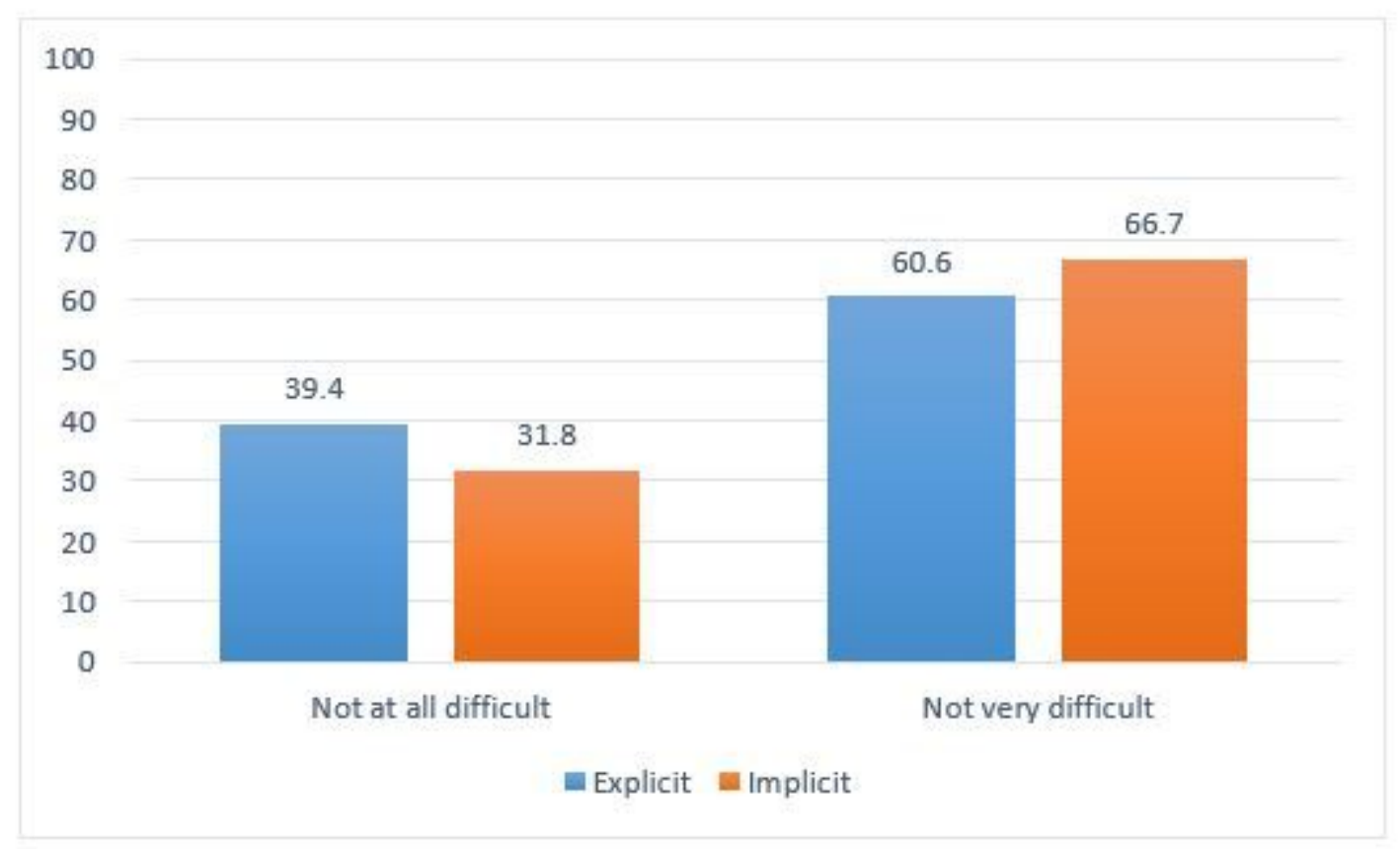

Figure 23

Percentages on difficulty of explicit vs. implicit learning of pragmatic features of speech acts of apologies 


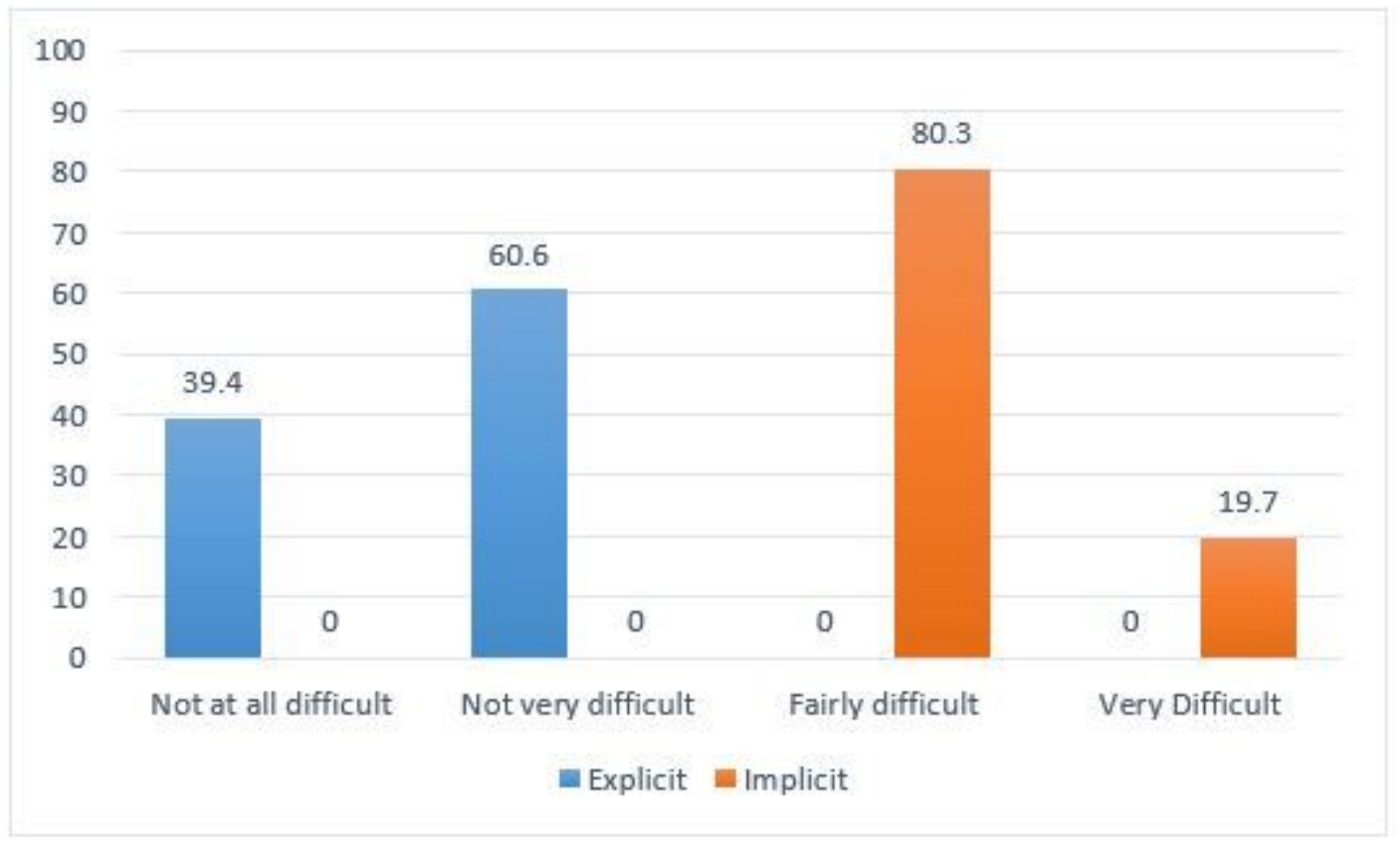

\section{Figure 24}

Percentages on difficulty of explicit vs. implicit learning of pragmatic features of speech acts of request

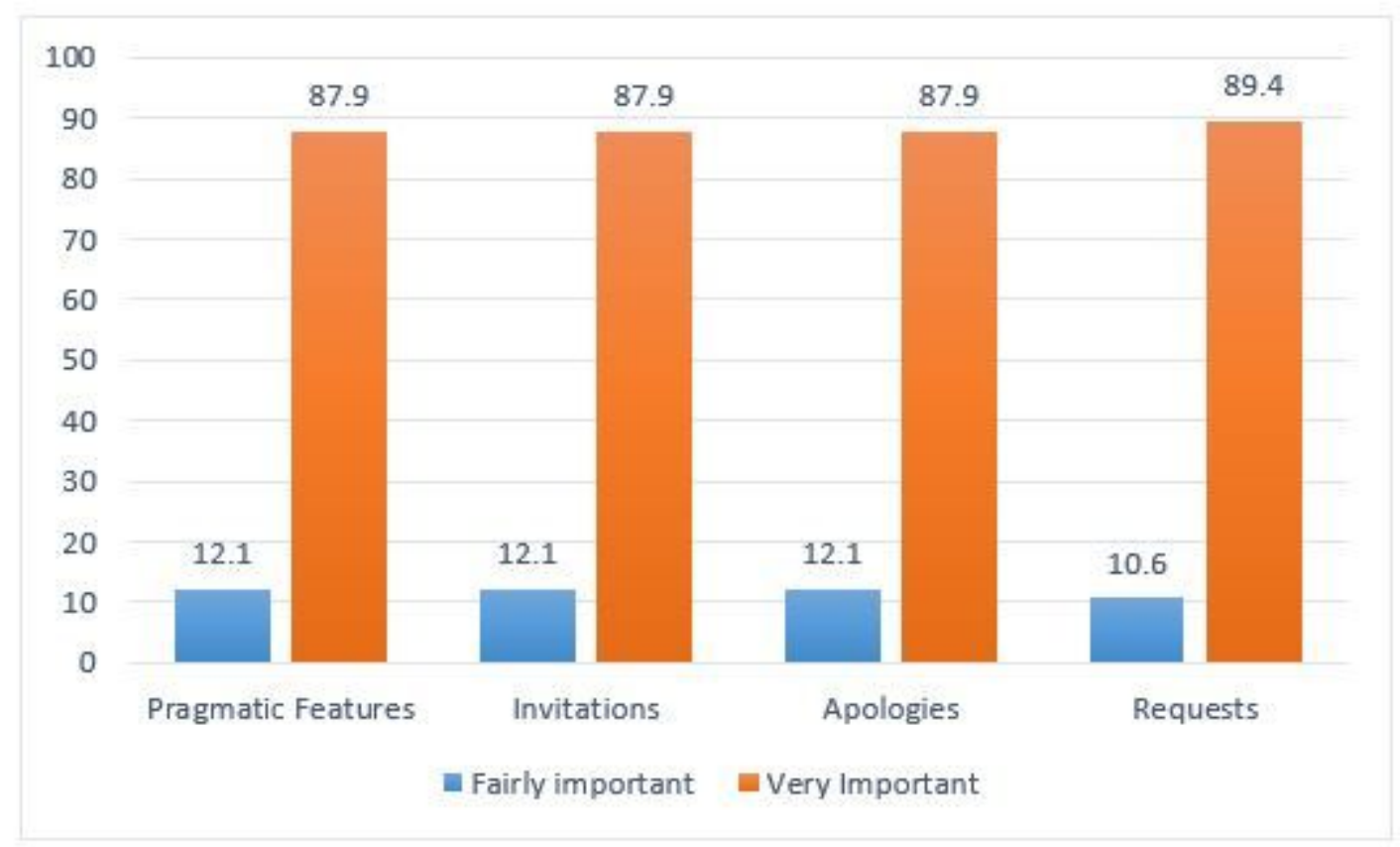

Figure 25

Percentages of importance of explicit learning of speech acts 


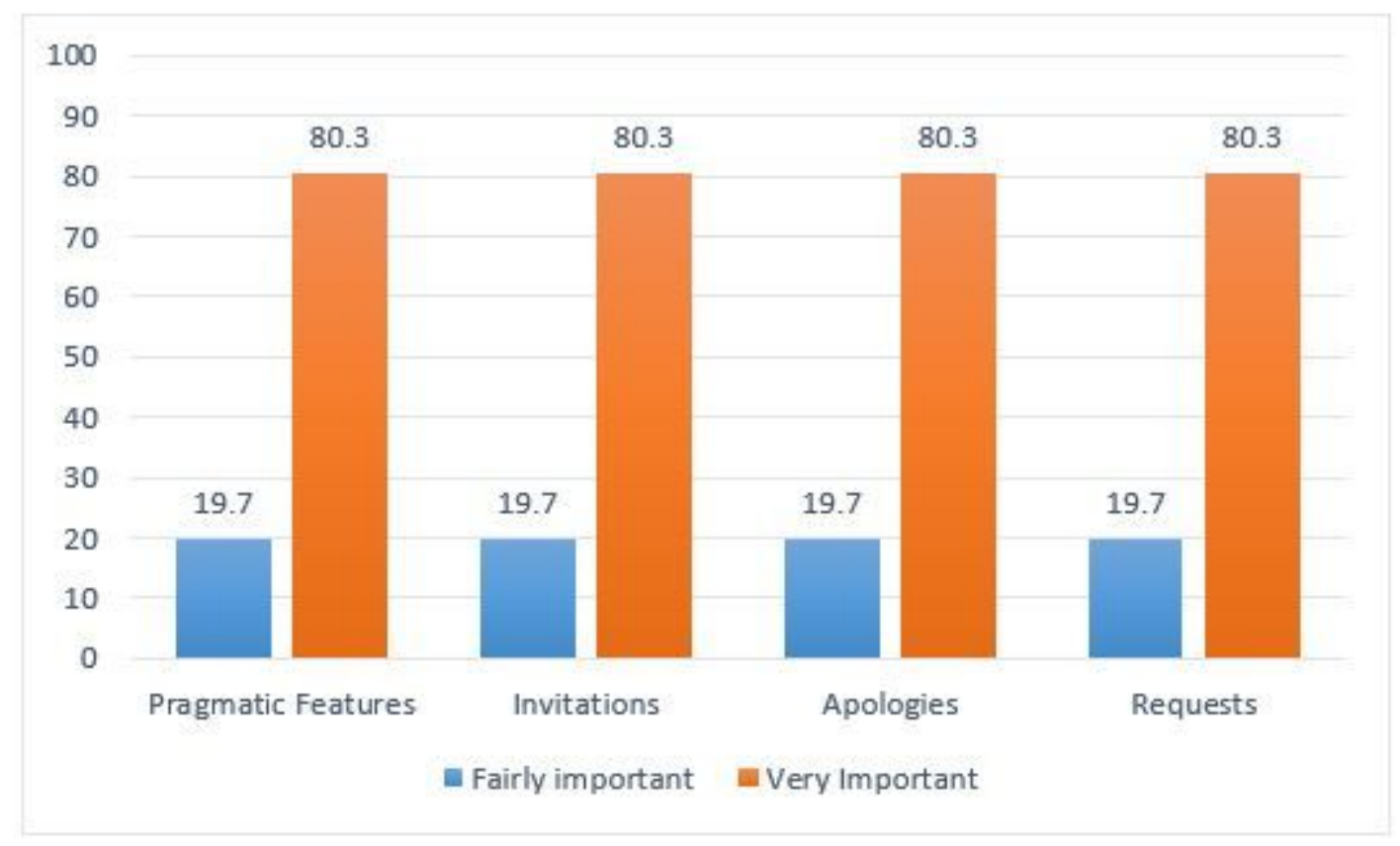

\section{Figure 26}

Percentages of importance of implicit learning of speech acts

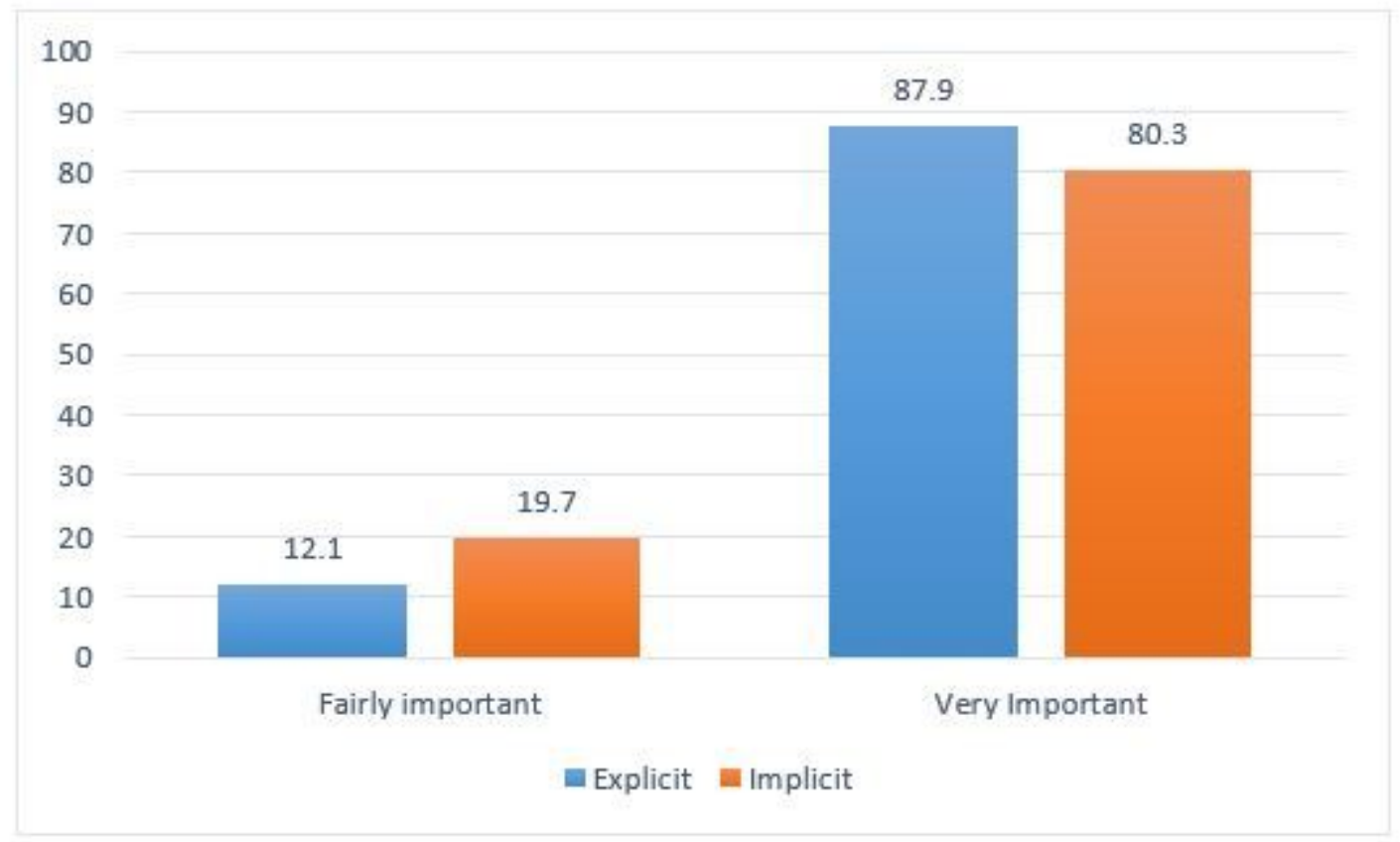

Figure 27

Percentages of importance of explicit vs. implicit learning of pragmatic features of speech acts 


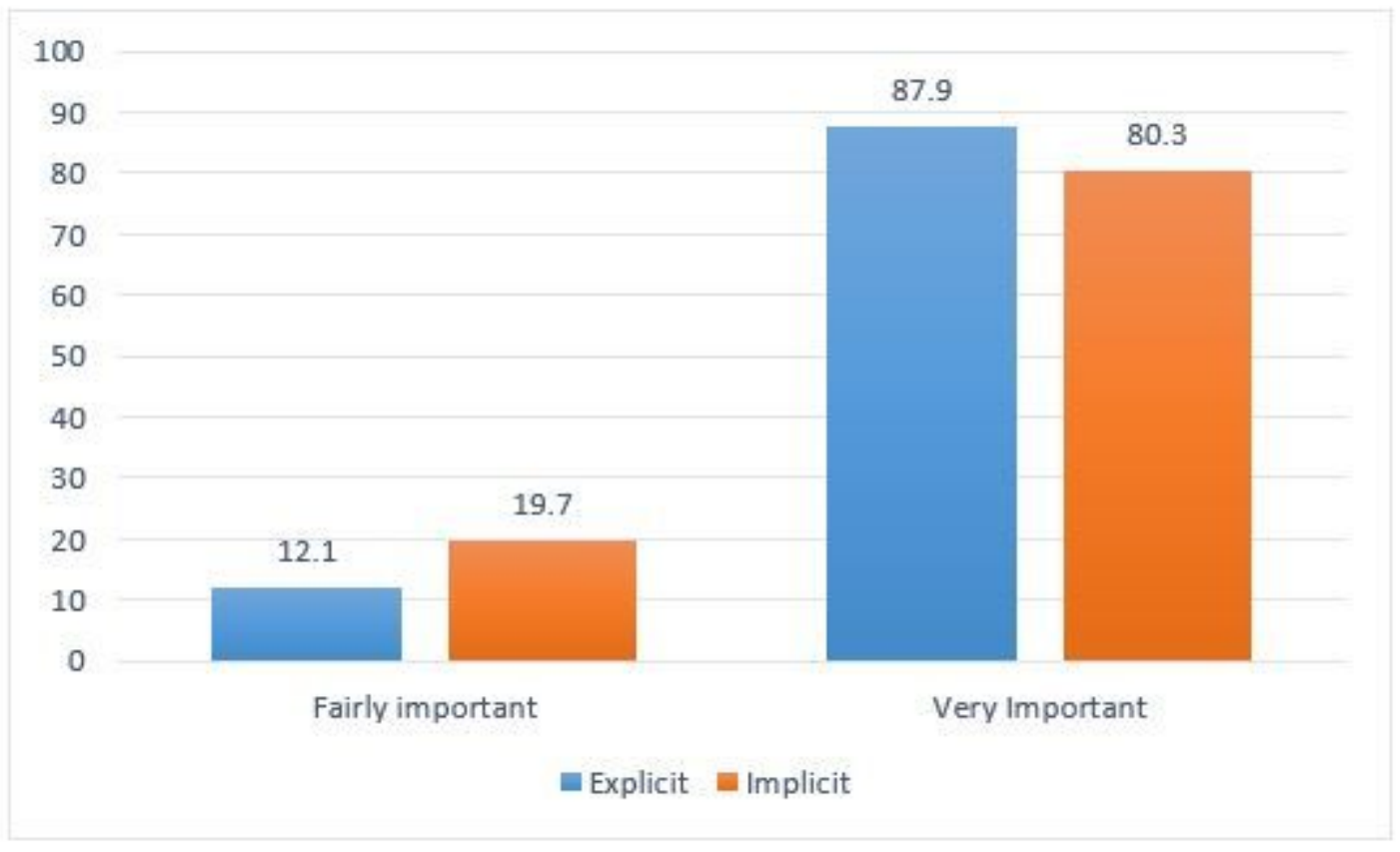

\section{Figure 28}

Percentages on importance of explicit vs. implicit learning of pragmatic features of speech acts of invitations

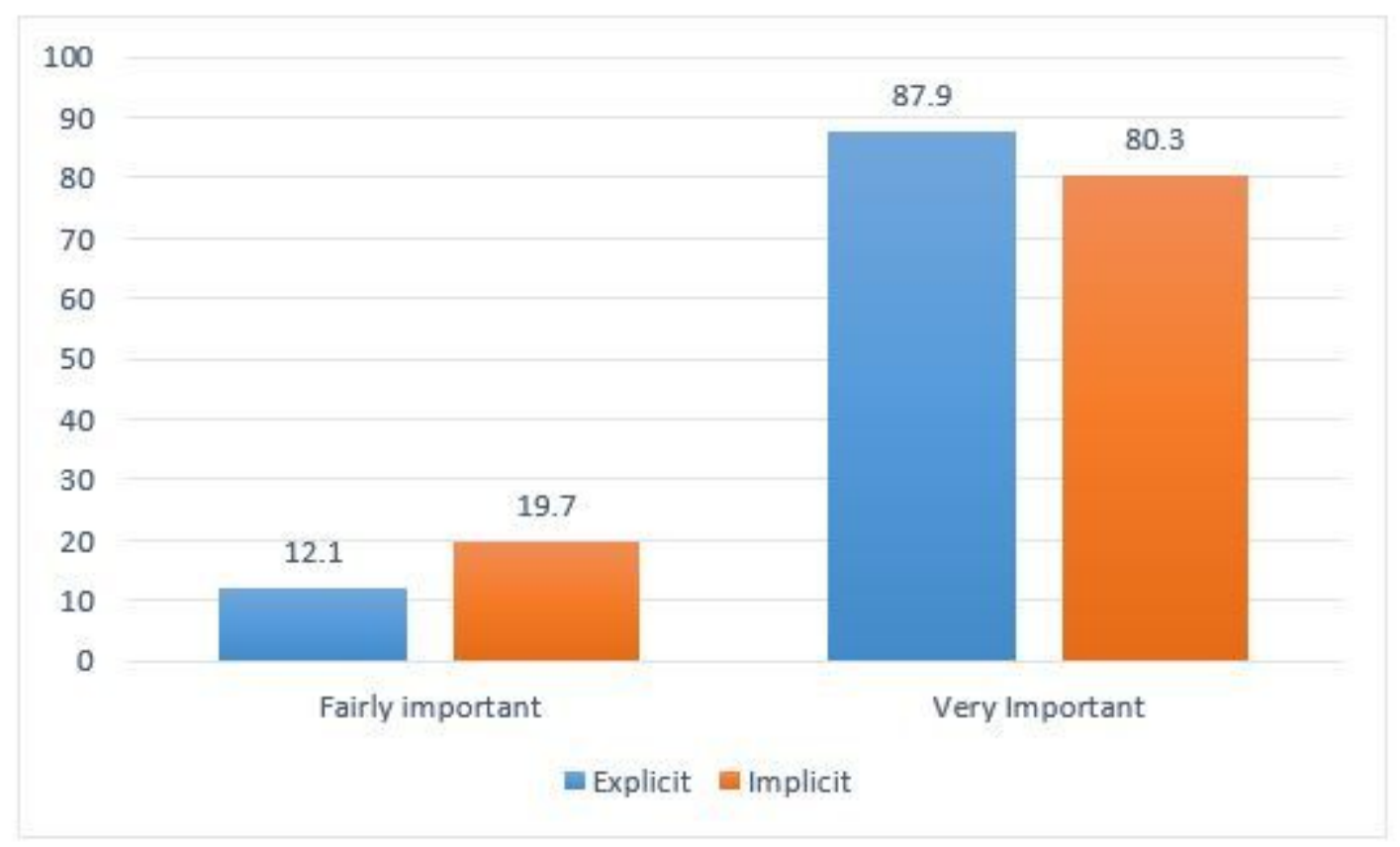

\section{Figure 29}

Percentages on importance of explicit vs. implicit learning of pragmatic features of speech acts of apologies 


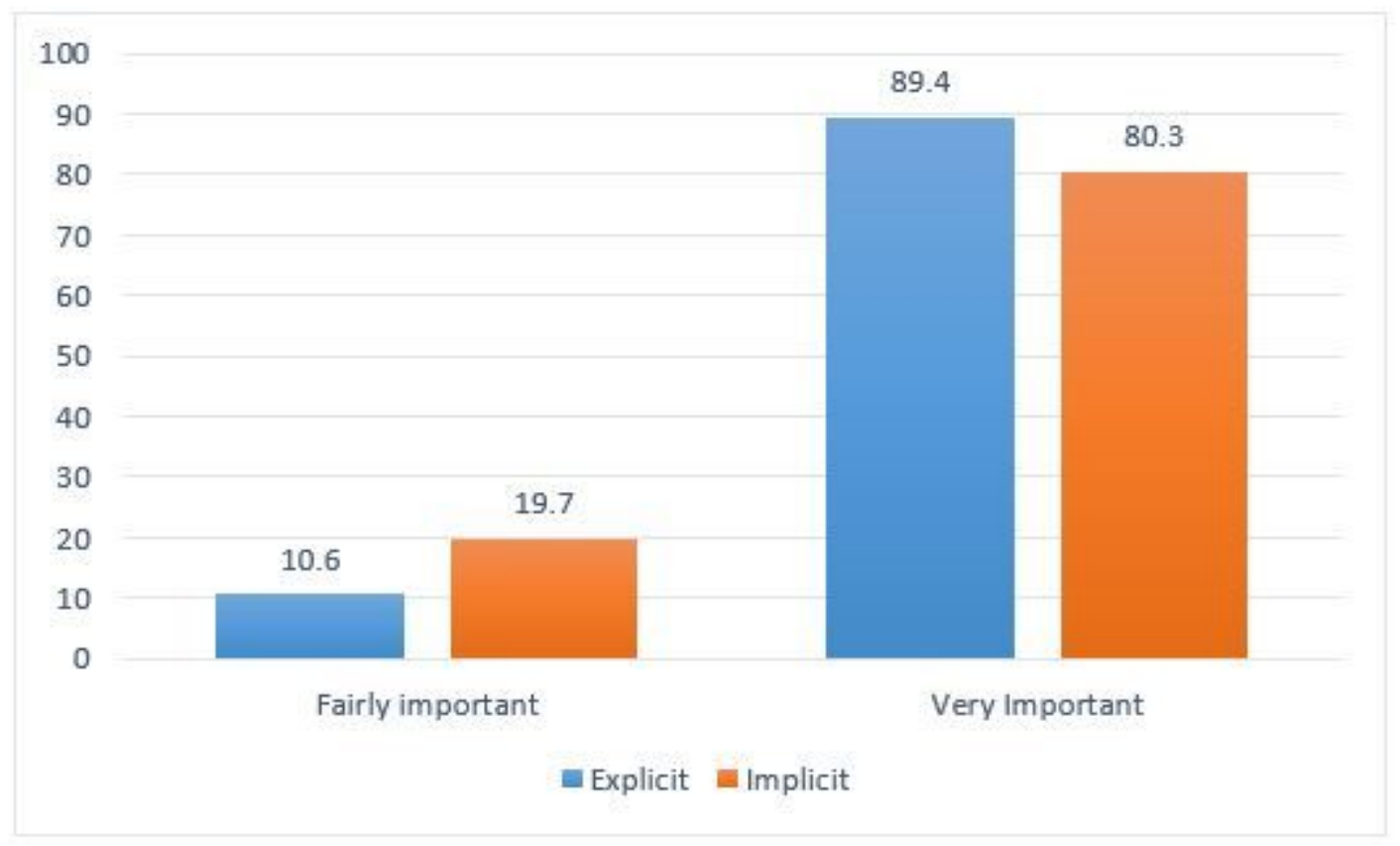

\section{Figure 30}

Percentages on importance of explicit vs. implicit learning of pragmatic features of speech acts of request

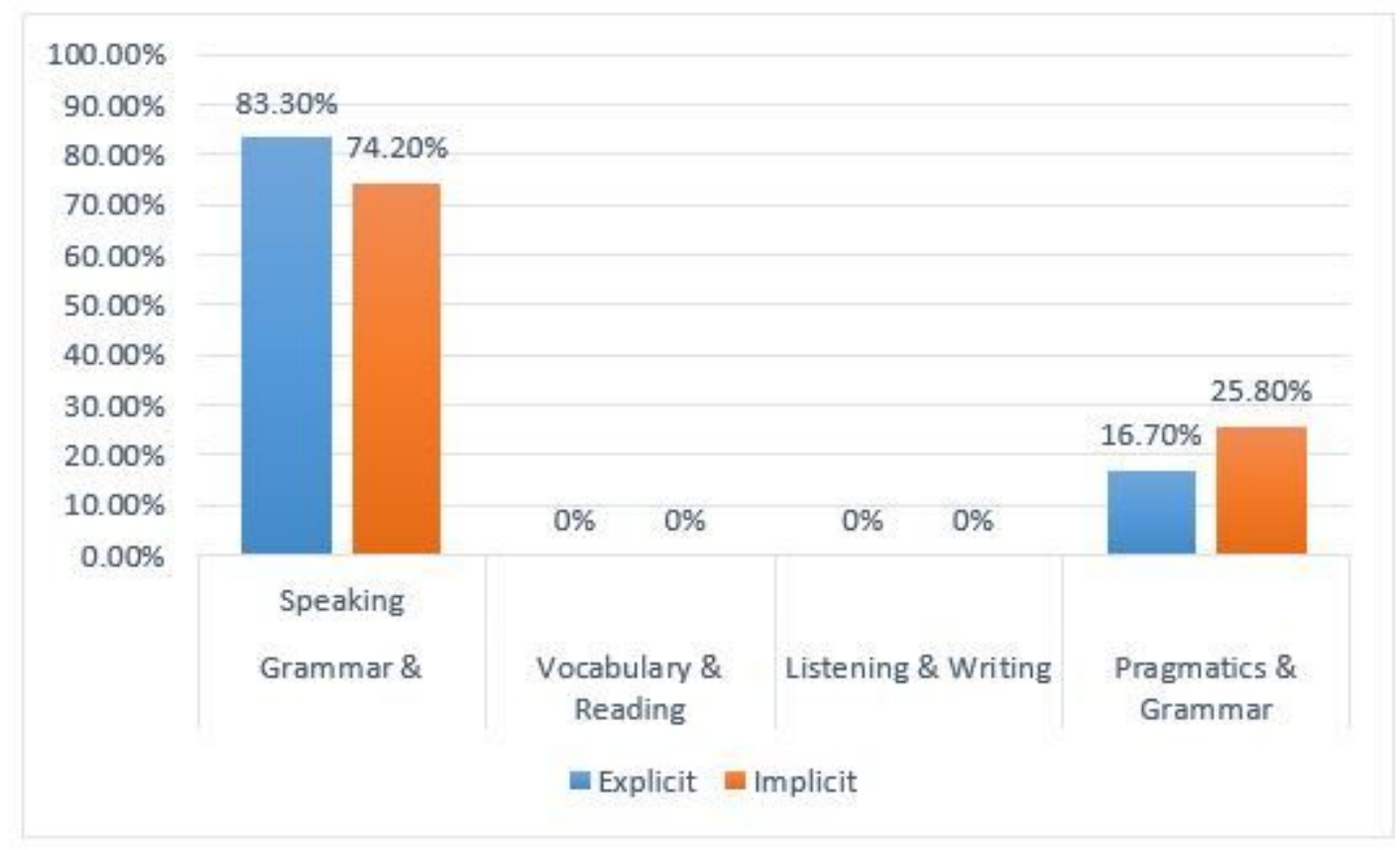

\section{Figure 31}

Percentages of important topics/skills to be learnt in English classes 


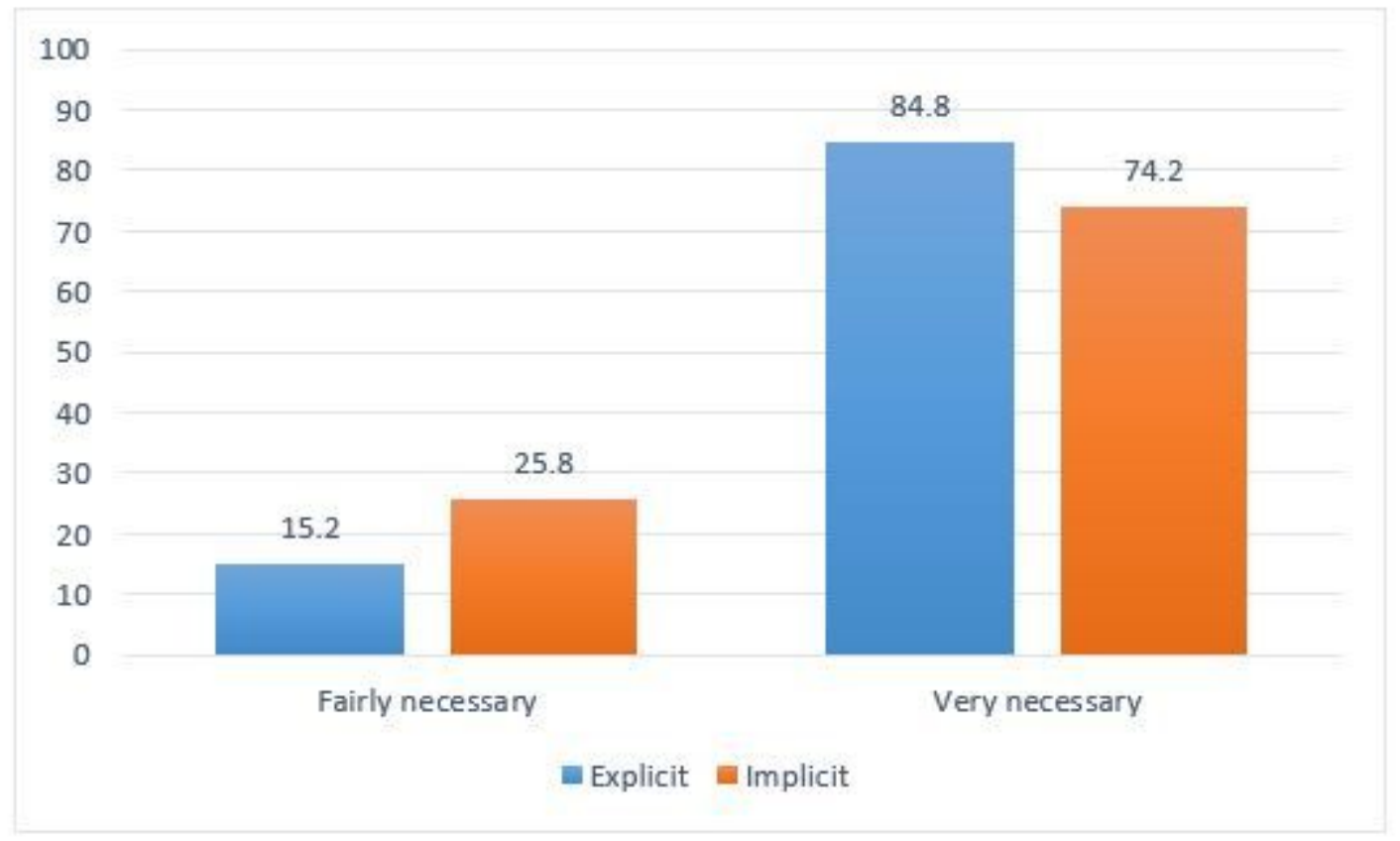

\section{Figure 32}

Percentages of necessity of learning pragmatic features of speech acts by groups

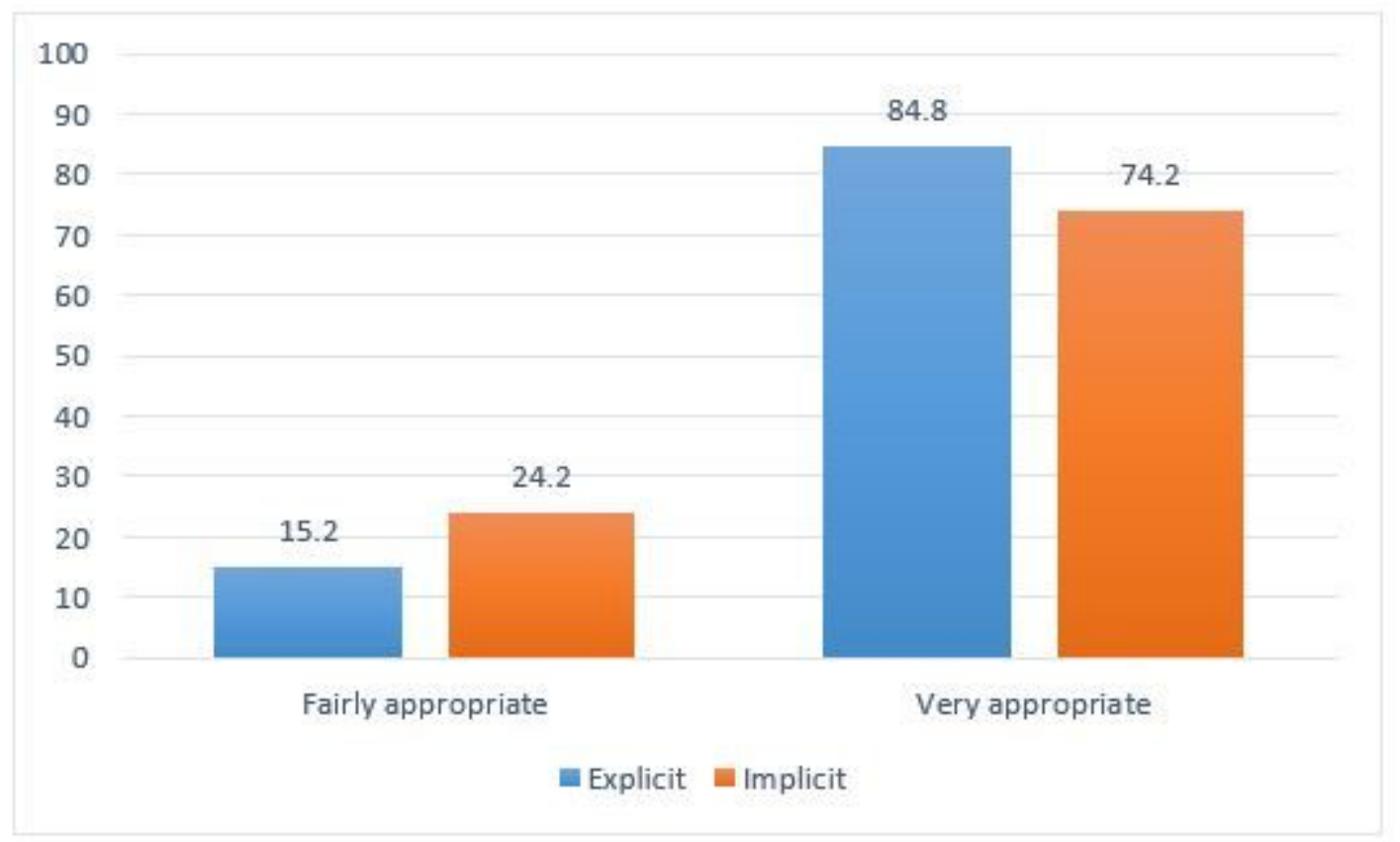

\section{Figure 33}

Percentages of suitability of movies in learning pragmatics by groups 


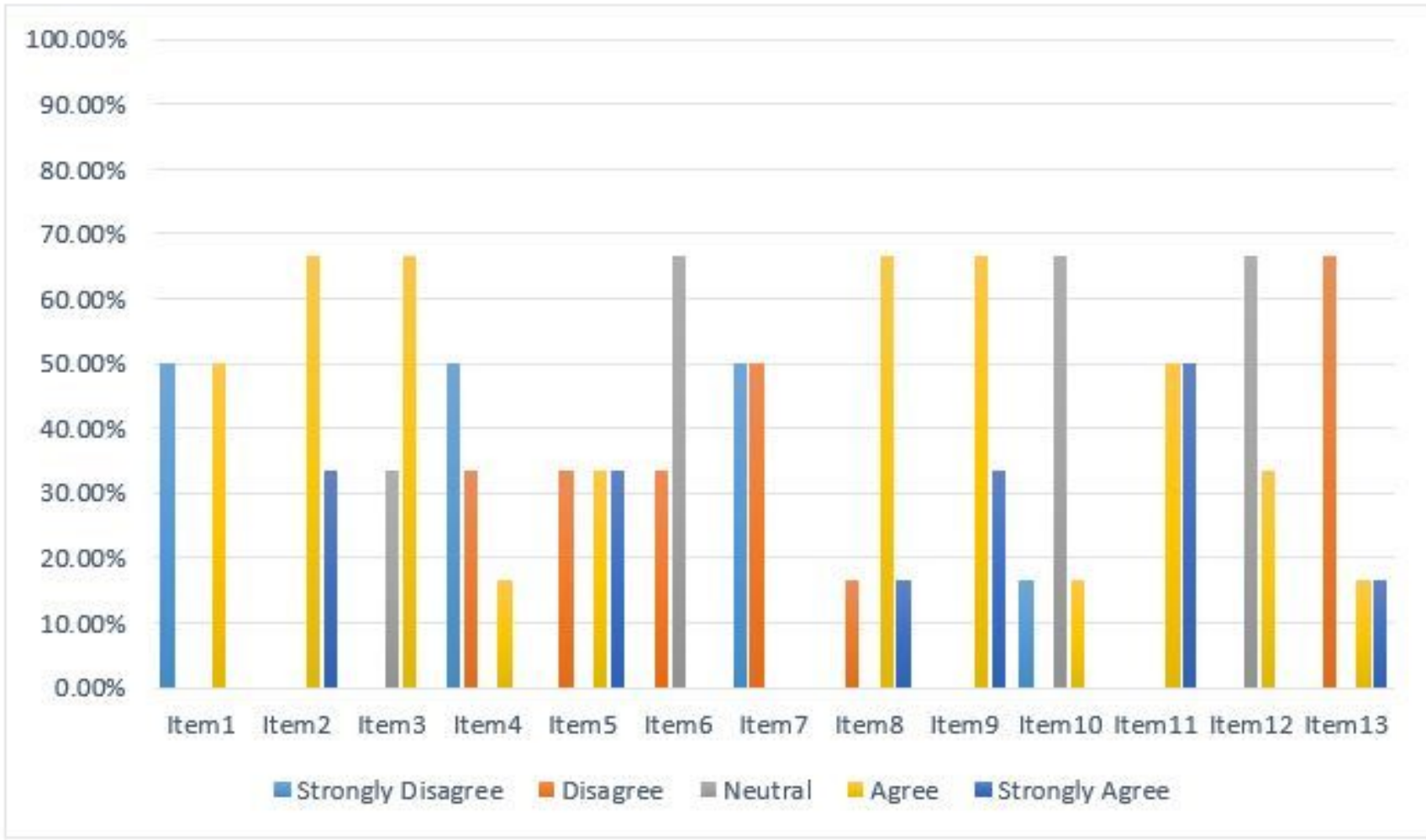

Figure 34

Percentages of teachers' perceptions towards pragmatics 